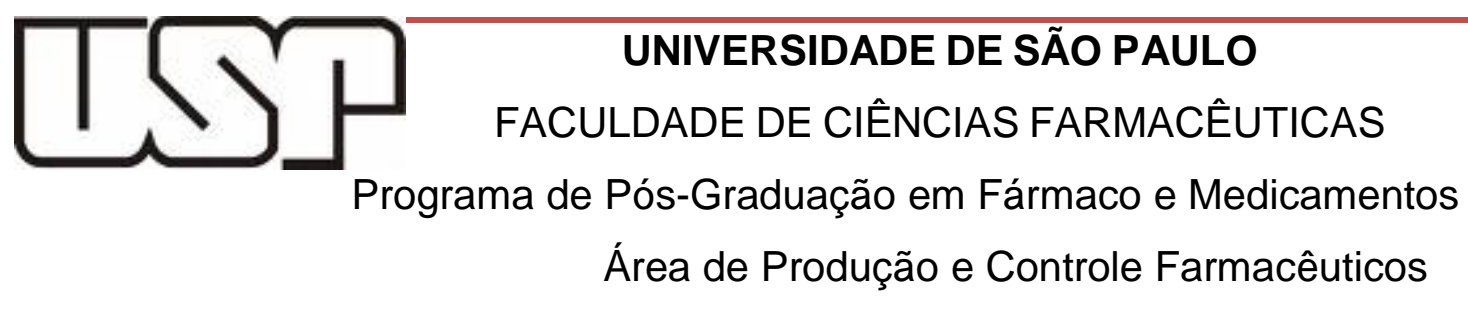

\title{
Estudo analítico de anestésicos injetáveis e validação de estabilidade
}

Farid Capanema Merheb

Dissertação para o grau de

MESTRE

Orientadora

Dra Érika Rosa Maria Kedor-Hackmann 


\title{
UNIVERSIDADE DE SÃO PAULO \\ FACULDADE DE CIÊNCIAS FARMACÊUTICAS \\ Programa de Pós-Graduação em Fármaco e Medicamentos \\ Área de Produção e Controle Farmacêuticos
}

\section{Estudo analítico de anestésicos injetáveis e validação de estabilidade}

\author{
Farid Capanema Merheb
}
Dissertação para o grau de MESTRE

Orientadora

Prof $^{a}$. Dra. Érika Rosa Maria Kedor-Hackmann 


\section{Ficha Catalográfica}

Elaborada pela Divisão de Biblioteca e Documentação do Conjunto das Químicas da USP

Merheb, Farid Capanema
M559e Estudo analítico de anestésicos injetáveis e validação de estabilidade / Farid Capanema Merheb. -- São Paulo, 2014. $97 \mathrm{p}$.

Dissertação (mestrado) - Faculdade de Ciências Farmacêuticas da Universidade de São Paulo. Departamento de Farmácia.

Orientador : Kedor-Hackmann, Érika Rosa Maria

1. Medicamento : Controle de qualidade 2. Estabilidade : Medicamento : Análise farmacêutica I. T. II. Kedor-Hackmann, Érika Rosa Maria, orientador. 
Farid Capanema Merheb

Estudo analítico de anestésicos injetáveis e validação de estabilidade

Comissão Julgadora

da

Dissertação para obtenção do grau de

MESTRE

Prof $^{\mathrm{a}}$. Titular Dra. Érika Rosa Maria Kedor-Hackmann

Orientadora/Presidente

$1^{\circ}$ Examinador

2ำExaminador

São Paulo, de

de 2014 


\section{AGRADECIMENTOS}

- À professora Dra Érika Rosa Maria Kedor-Hackmannpela eficiente orientação durante todo o período de pesquisa na Universidade de São Paulo;

- À professora $\mathrm{Dr}^{\mathrm{a}}$ Terezinha de Jesus Andreóli Pinto, pela indicação dos professores da FCF para o início das pesquisas em controle físico-químico de qualidade;

- Ao professor Dr Anil K. Singh pelas primeiras orientações com relação à elaboração do projeto de pesquisa e demais contribuições;

- À professora Drª Maria Aurora Prado, pela importante contribuição em relação à aplicação da técnica de Eletroforese Capilar;

- À professora Drª Maria Inês Rocha Miritello Santoro por toda a atenção dispensada durante o desenvolvimento das pesquisas.

- À professora $\mathrm{Dr}^{\mathrm{a}}$ Elfriede Marianne Bacchi, pelo apoio junto ao departamento de farmacognosia.

- À professora Drª Elizabeth Igne Ferreira pelo apoio junto à central analítica.

- À Aluna de doutorado Lorena Cristine Paes, pela importante contribuição na utilização dos equipamentos da central analítica.

- Aos colegas do departamento de controle físico químico de qualidade pela importante troca de informações durante o período de mestrado. 


\section{SUMÁRIO}

RESUMO............................................................................................................ 07

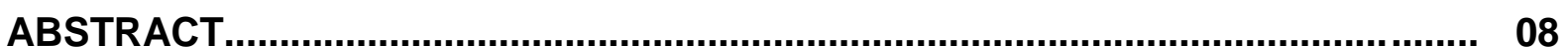

LISTA DE FIGURAS.......................................................................................... 09

LISTA DE TABELAS....................................................................................... 11

LISTA DE ABREVIATURAS E SÍMBOLOS........................................................ 12

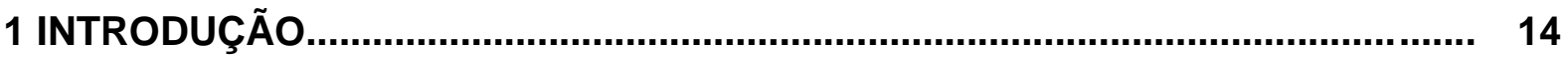

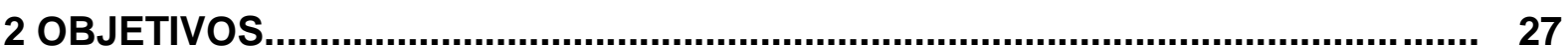

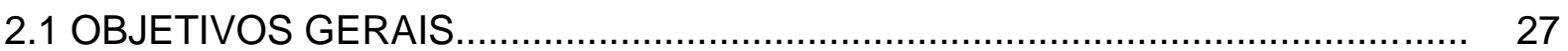

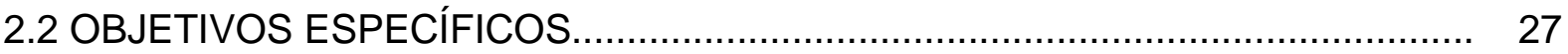

3 REVISÃO DE LITERATURA.......................................................................... 28

3.1 CLORIDRATO DE BUPIVACAÍNA INJETÁVEL........................................... 28

3.1.1 Características físico-químicas............................................................... 28

3.1.2 Propriedades farmacodinâmicas........................................................... 29

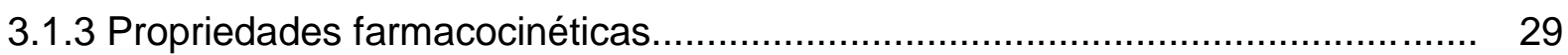

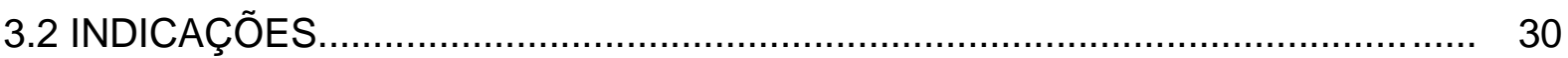

3.3 DESCRIÇÃO E CARACTERIZAÇÃO DAS IMPUREZAS................................. 31

3.3.1 Análise dos padrões analíticos das impurezas por cromatografia líquida de alta eficiência ...................................................................................... 32

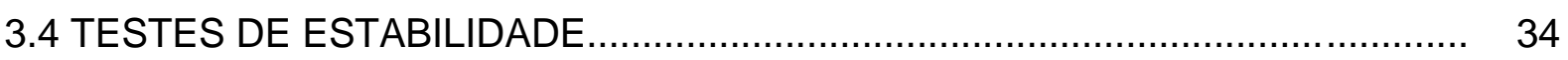

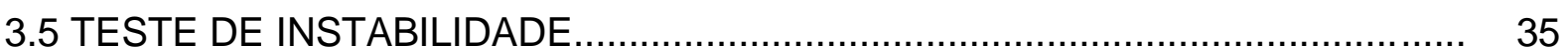

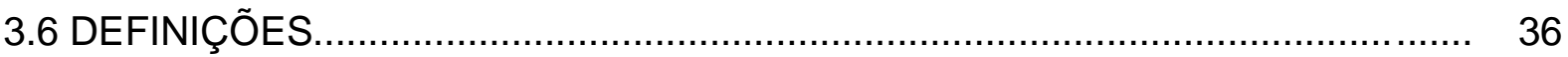

3.6.1 Estudos de estabilidade acelerada........................................................... 36

3.6.2 Estudos de estabilidade de longa duração.................................................. 36

3.6.3 Estudos de estabilidade de acompanhamento............................................ 36

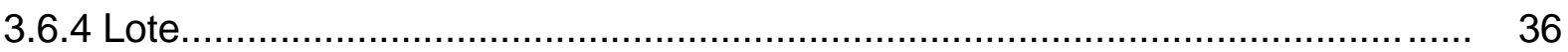

3.6.5 Período de utilização............................................................................ 37

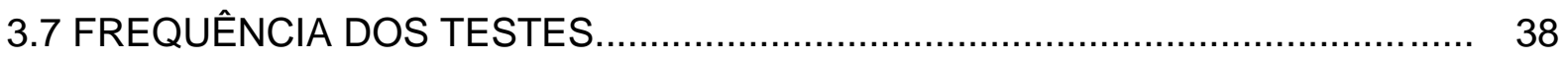

4 INTRODUÇÃO DA TÉCNICA DE ANÁLISE.................................................... 39

4.1 CROMATOGRAFIA LÍQUIDA DE ALTA EFICIÊNCIA.................................... 39

4.2 PROCEDIMENTOS EXPERIMENTAIS .................................................... 41

4.2.1 Características principais do CLAE utilizado na pesquisa.............................. 41

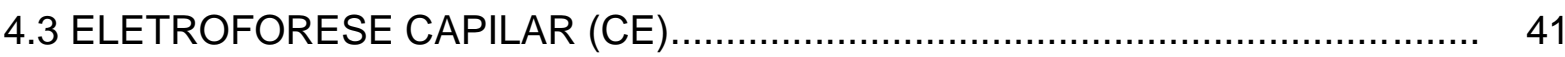

5 CLORIDRATO DE BUPIVACAÍNA SOLUÇÃO INJETÁVEL - FARMACOPEIA 
BRASILEIRA.

5.1 ENSAIOS DE PUREZA............................................................................ 43

5.1.1 Substâncias relacionadas........................................................................ 43

5.1.2 Testes de segurança biológica................................................................. 44

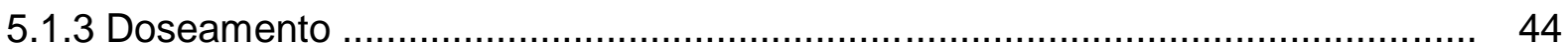

5.2 METODOLOGIAS ALTERNATIVAS PARA DETECÇÃO DO CLORIDRATO

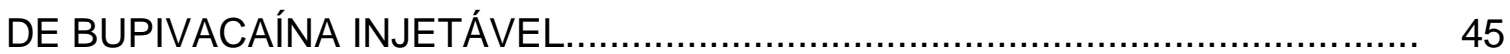

5.2.1 Determinação de anestésicos locais e suas impurezas em preparações farmacêuticas usando HPLC com detecção amperométrica............................ 45

5.2.2 Substância analisada............................................................................... 46

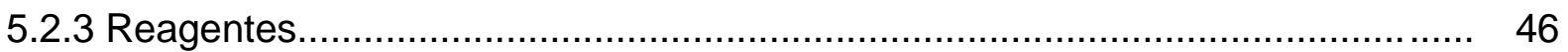

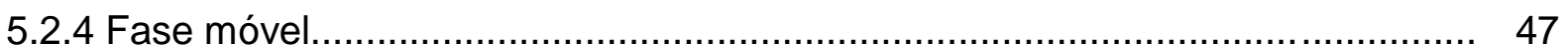

5.2.5 Solução padrão....................................................................................... 47

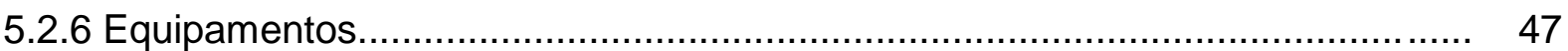

5.3 PREPARAÇÕES DE AMOSTRAS E DETERMINAÇÃO DE BUPIVACAÍNA

NAS FORMULAÇÕES FARMACÊUTICAS ................................................. 47

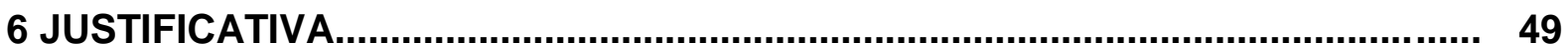

7 MATERIAL, MÉTODOS E REAGENTES.......................................................... 50

8 FORMA DE ANÁLISE DOS RESULTADOS - PARTE EXPERIMENTAL................ 51

8.1 ATIVIDADES DE PESQUISA EM LABORATÓRIO .......................................... 51

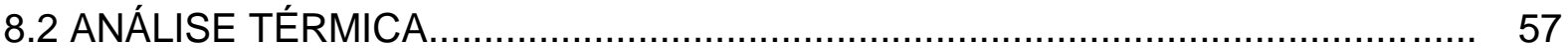

8.2.1 Métodos térmicos................................................................................. 57

8.2.2 Cromatografia em camada delgada......................................................... 58

8.2.3 Análise em cromatografia líquida de alta eficiência........................................ 61

8.3 LIMITES DE DETECÇÃO E LIMITES DE QUANTIFICAÇÃO............................ 64

8.4 VALIDAÇÃO DA METODOLOGIA......................................................... 67

\section{ANÁLISE DO MEDICAMENTO INDUSTRIAL POR CROMATOGRAFIA}

LÍQUIDA DE ALTA EFICIÊNCIA.................................................................... 68

10 CINÉTICA QUÍMICA E CONTROLE DA QUALIDADE DE

MEDICAMENTOS.

10.1 MÉTODOS DE TRIAGEM PARA A DETERMINAÇÃO DA ESTABILIDADE DE MEDICAMENTOS

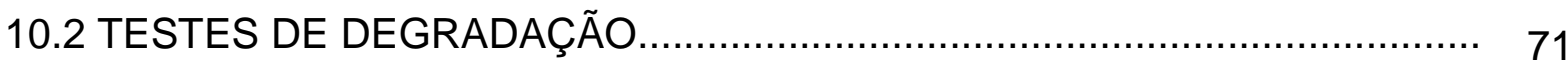

10.2.1 Ensaios de estabilidade de medicamentos........................................ 71

10.2.2 Degradação por hidrólise. 
10.2.3 Degradação por hidrólise ácida.......................................................... 75

10.2.4 Degradação por oxidação com peróxido de hidrogênio $\left(\mathrm{H}_{2} \mathrm{O}_{2}\right) \ldots \ldots \ldots \ldots \ldots \ldots . . . . .76$

10.2.5 Teste de fotoestabilidade................................................................... 79

10.2.6 Discussão dos resultados dos testes de degradação............................... 80

10.3 APLICAÇÃO DA TÉCNICA DE ELETROFORESE CAPILAR....................... 81

10.3.1 Análise dos padrões analíticos das impurezas por eletroforese capilar...... 83

10.3.2 Análise do medicamento industrial por eletroforese capilar..................... 84

10.3.3 Análise dos dados experimentais por EC ............................................ 86

10.3.4 Validação da metodologia analítica..................................................... 87

11 DISCUSSÃO DOS RESULTADOS........................................................ 89

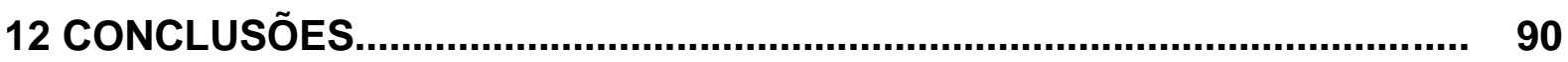

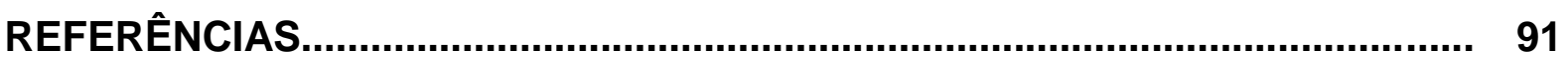




\section{RESUMO}

MERHEB, F.C. Estudo analítico de anestésicos injetáveis e validação de estabilidade. 2014. 97f. Dissertação (Mestrado) - Faculdade de Ciências Farmacêuticas,Universidade de São Paulo, São Paulo, 2014.

O consumo de medicamentos de qualidade é pré-requisito básico para o reestabelecimento da saúde dos indivíduos. No trabalho de pesquisa desenvolvido na faculdade de ciências farmacêuticas da Universidade de São Paulo(USP), destacou-se o controle físico-químico da qualidade dos medicamentos, as principais metodologias adotadas nos laboratórios de controle de qualidade enfatizando-se a identificação e quantificação das impurezas, e de que forma as mesmas são geradas nos processos de fabricação e armazenamento dos medicamentos. Evidencia-se a importância da atuação de órgãos de vigilância sanitária como a Agência Nacional de Vigilância Sanitária (ANVISA) através da consulta da legislação específica das Boas Práticas de Fabricação. Neste contexto, explorou-se o estudo de um medicamento anestésico injetável utilizadoem ambiente hospitalar que está apresentando diversas notificações de desvios de qualidade, através de queixas técnicas e eventos adversos recebidos no sistema de notificações(Notivisa) da Agência Nacional de Vigilância Sanitária. Para a pesquisa, o mestrando utilizou diferentes métodos de identificação, citando-se a cromatografia de camada delgada, espectroscopia no infravermelho, ponto de fusão, espectroscopia UV-Vis e termoanálise. Para a identificação e quantificação, destacou-se a cromatografia líquida de alta eficiência(CLAE) e eletroforese capilar(EC). As pesquisas foram relizadas no laboratório de controle físico químico de qualidade e central analítica da faculdade de ciências farmacêuticas da Universidade de São Paulo.

Palavras-chave: Cromatografia; Eletroforese; Bupivacaína; Controle; Anestésico. 


\begin{abstract}
Analytical study of injectable anesthetics and validation of stability

The use of medicines of good qualityis a basicprerequisite forthe re-establishmentof the health ofdisabledpatients. Thisresearch, developed in the Laboratory of Physical and Chemical Quality Control of Pharmaceutical Preparations and Cosmetics and Central Analytical Center at theFaculty of PharmaceuticalSciences-University of São Paulo, aims the studyand application ofthe main and newmethodologies usedin qualitycontrol laboratories. It was emphasizedthe identification andquantification ofimpuritiesand howthey can begeneratedin the manufacturing processesand storage of pharmaceutical preparations. It was evidenced the importanceof theroleof health surveillanceagenciessuch as the NationalHealth Surveillance Agency(ANVISA) through theconsultation of the specific legislationof GoodManufacturing Practices (GMP). In this context, the local anesthetic drug, bupivacaine in injectables, was selected for the study. This formulation is very much used in hospitals, and recently, several complaints of quality deviations related to technical complaints and adverse events were made through the ANVISA notification system. Several analytical methods were used for identification, such as, thin layer chromatography, infrared spectroscopy, determination of the melting point, UV-VIS spectrophotometry, and termoanalysis. For identification and quantification of the degradation products, high performance liquid chromatography (HPLC) and capillary electrophoresis (CE) were used in the research.
\end{abstract}

Keywords: Chromatography; Electrophoresis; Anesthetic; Bupivacaine; Quality Control. 


\section{LISTA DE FIGURAS}

Figura 1 - Fórmula estrutural do cloridrato de bupivacaína ........................... 27

Figura 2 - Fórmula estrutural da 0 -TLD................................................... 30

Figura 3 - Fórmula esrutural da 2,6 DMA.............................................. 31

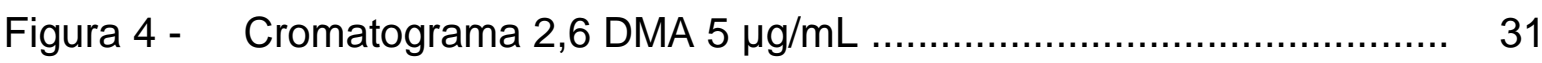

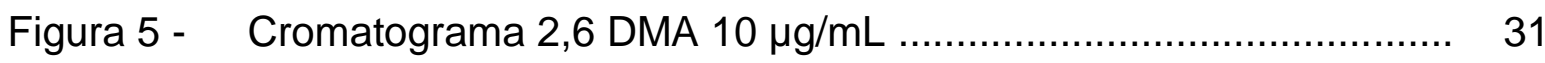

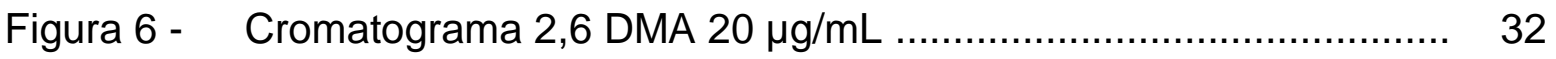

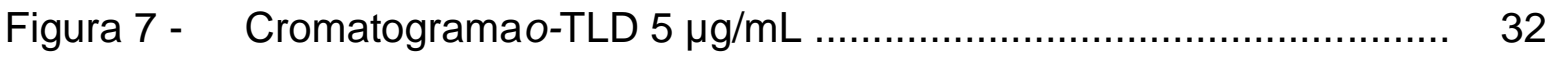

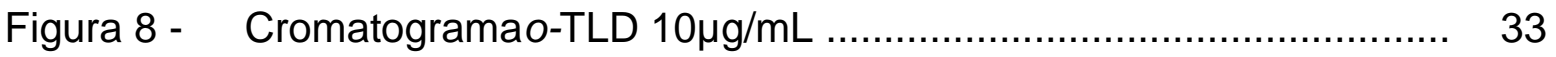

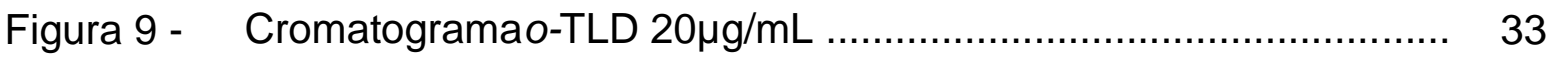

Figura 10 - Esquema de um sistema de CLAE ........................................... 40

Figura 11 - Representação em diagrama dos blocos do equipamento de eletroforesecapilar construído em laboratório .............................. 41

Figura 12 - Espectro de absorção do cloridrato de bupivacaína por UV-Vis .... 53

Figura 13 - Espectro de absorção padrão em IV para o cloridrato de bupivacaína .................................................................. 54

Figura 14 - Espectro de transmitância padrão em IV para o cloridrato de bupivacaína

Figura 15 - Espectro de IV para o cloridrato de bupivacaína obtido no laboratório do Instituto de Química da Universidade de São Paulo

Figura 16 - Curva DTA/TGA obtida no laboratório do Instituto de Química da Universidade de São Paulo

Figura 17 - Curva DSC obtida no laboratório do Instituto de Química da Universidade de São Paulo

Figura 18 - Cromatograma em desenvolvimento ......................................... 58

Figura 19 - Determinação do valor de Rf ................................................. 59

Figura 20 - Placa de Cromatografia em Camada Delgada (CCD) ................. 60

Figura 21 - Branco da fase móvel........................................................... 61

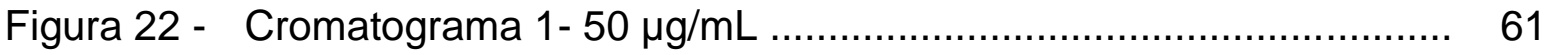

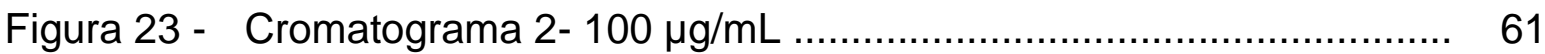

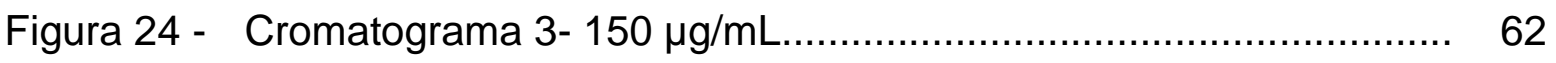

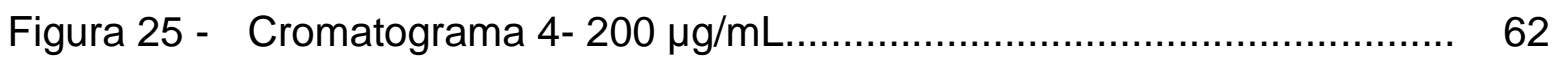




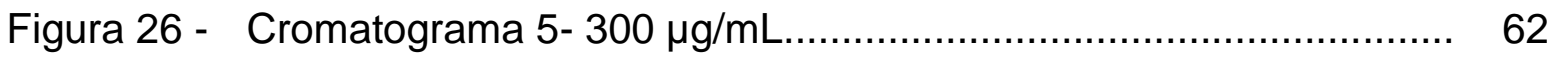

Figura 27 - Curva de calibração em CLAE do cloridrato de bupivacaína ......... 65

Figura 28 - Cromatograma1 do medicamento industrial, $100 \mu \mathrm{g} / \mathrm{mL} \ldots \ldots \ldots \ldots \ldots . . .66$

Figura 29 - Cromatograma2 do medicamento industrial, $200 \mu \mathrm{g} / \mathrm{mL} \ldots \ldots \ldots \ldots \ldots . . .68$

Figura 30 - Cromatograma3 do medicamento industrial, $300 \mu \mathrm{g} / \mathrm{mL} \ldots \ldots \ldots \ldots \ldots . . .68$

Figura 31 - Cromatograma hidrólise branco .............................................. 72

Figura 32 - Cromatograma hidrólise ponto zero ……................................ 72

Figura 33 - Cromatograma hidrólise 7 dias …........................................... 73

Figura 34 - Cromatograma hidrólise 14 dias .............................................. 73

Figura 35 - Cromatograma hidrólise 21 dias ............................................. 73

Figura 36 - Cromatograma hidrólise ácida branco ..................................... 74

Figura 37 - Cromatograma hidrólise ácida ponto zero …….......................... 74

Figura 38 - Cromatograma hidrólise ácida 7 dias ….................................... 75

Figura 39 - Cromatograma hidrólise ácida 14 dias ....................................... 75

Figura 40 - Cromatograma hidrólise ácida 21 dias ...................................... 75

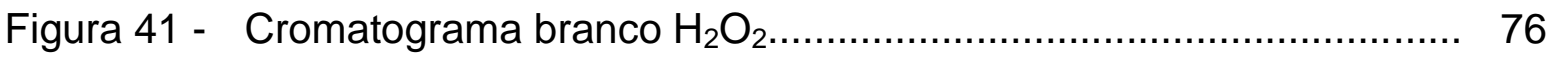

Figura 42 - Cromatograma $\mathrm{H}_{2} \mathrm{O}_{2}$ ponto zero............................................. 76

Figura 43 - Cromatograma $\mathrm{H}_{2} \mathrm{O}_{2} 7$ dias ................................................. 77

Figura 44 - Cromatograma $\mathrm{H}_{2} \mathrm{O}_{2} 14$ dias ............................................... 77

Figura 45 - Cromatograma $\mathrm{H}_{2} \mathrm{O}_{2} 21$ dias ............................................... 77

Figura 46 - Cromatograma branco fotólise ................................................. 78

Figura 47 - Cromatograma ponto zero fotólise …….................................. 78

Figura 48 - Cromatogramafotólise solução controle a $100 \mu \mathrm{g} / \mathrm{mL}$................ 79

Figura 49 - Cromatogramafotólise solução a $100 \mu \mathrm{g} / \mathrm{mL}$............................... 79

Figura 50 - Branco da solução eletrolítica para EC ....................................... 80

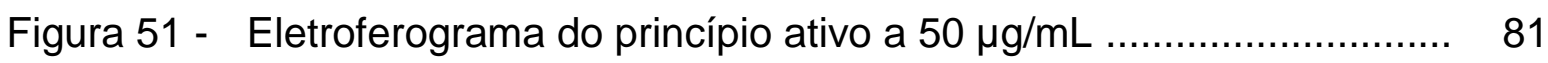

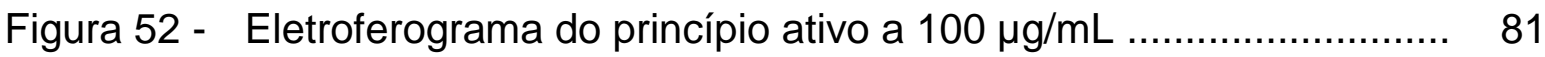

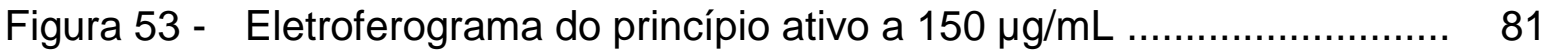

Figura 54 - Eletroferograma do princípio ativo a $200 \mu \mathrm{g} / \mathrm{mL}$........................ 82

Figura 55 - Eletroferograma do princípio ativo a $300 \mu \mathrm{g} / \mathrm{mL}$......................... 82

Figura 56 - Eletroferograma do padrão de 2,6 DMA a $20 \mu \mathrm{g} / \mathrm{mL}$................... 83

Figura 57 - Eletroferograma do padrão de $o-T L D$ a $20 \mu \mathrm{g} / \mathrm{mL}$...................... 83

Figura 58 - Eletroferograma do medicamento industrial a $100 \mu \mathrm{g} / \mathrm{mL} \ldots \ldots \ldots \ldots \ldots . . . \quad 84$ 
Figura 59 - Eletroferograma do medicamento industrial a $200 \mu \mathrm{g} / \mathrm{mL} \ldots \ldots \ldots \ldots . . \quad 84$

Figura 60 - Eletroferograma do medicamento industrial a $300 \mu \mathrm{g} / \mathrm{mL} \ldots \ldots \ldots \ldots \ldots . . . .84$

Figura 61 - Curva de calibração do cloridrato de bupivacaína em EC.............. 85

\section{LISTA DE TABELAS}

Tabela 1 - Ensaio de pureza constante na farmacopeia brasileira ............. 24

Tabela 2 - UV - VIS ……………............................................ 53

Tabela 3 - $\quad$ Tabela de concentração/observância em CLAE ........................ 64

Tabela 4 - $\quad$ Concentração/absorbância em EC......................................... 85 


\section{LISTA DE ABREVIATURAS E SÍMBOLOS}

ANVISA Agência Nacional de Vigilância Sanitária

AAS Ácido Acetil Salicílico

BPF Boas Práticas de Fabricação

BPM Boas Práticas de Manipulação

CCD Cromatografia de Camada Delgada

CLAE Cromatografia Líquida de Alta Eficiência

DMA Dimetilanilina

DP DesvioPadrão

DSC Differential Scanning Calorimetry

DTA Differential Thermal Analysis

DTG Differential Thermogravimetric Analysis

EB Executive Board

EC EletroforeseCapilar

EU Endotoxin Unit

FCF Faculdade de Ciências Farmacêuticas

FDA FoodandDrugAdministration

g Grama

GC Cromatografia Gasosa

GGIMP Gerência Geral da Fiscalização de Insumos, Medicamentos e Produtos

$\mathrm{H}_{2} \mathrm{O}_{2} \quad$ Peróxido de Hidrogênio

IC Inclinação da Curva de Calibração

IQ Instituto de Química

IV Infravermelho

LD Limite de Detecção

LQ Limite de Quantificação

$\min \quad$ Minuto

mg Miligrama

$\mathrm{mL} \quad$ Mililitro

nm Nanômetros

OMS Organização Mundial da Saúde

o-TLD o-toluidine 


$\begin{array}{ll}\text { pH } & \text { Potencial Hidrogeniônico } \\ \text { PI } & \text { Período de Indução } \\ \text { PMV } & \text { Plano Mestre de Validação } \\ \text { POP } & \text { Procedimento Operacional Padrão } \\ \text { ppm } & \text { Partes por milhão } \\ \text { PPX } & \text { Pipecolilxilidina } \\ \text { PV } & \text { Protocolo de Validação } \\ \text { QD } & \text { Qualificação de Desempenho } \\ \text { QI } & \text { Qualificação de Instalação } \\ \text { QO } & \text { Qualificação de Operação } \\ \text { QT } & \text { Queixas Técnicas } \\ \text { RDC } & \text { Resolução da Diretoria Colegiada } \\ \text { RV } & \text { Relatório de Validação } \\ \text { SDS } & \text { Dodecil Sulfato de Sódio } \\ \text { SPGV } & \text { Solução Parenteral de Grande Volume } \\ \text { UnB } & \text { Universidade de Brasília } \\ \text { USP } & \text { Universidade de São Paulo } \\ \text { UV } & \text { Ultravioleta } \\ \text { UV-vis } & \text { Ultravioleta Visível } \\ \text { VP } & \text { Validação de Processo } \\ \mu \mathrm{Mg} & \text { Micrograma } \\ \mu \text { L } & \text { Microlitro } \\ \text { A } & \text { Lambda (Comprimento de Onda) }\end{array}$




\section{INTRODUÇÃO}

O produto final do processo de fabricação é submetido ao controle da qualidade para garantir que os componentes principais estejam dentro de determinadas faixas de composição e que as eventuais impurezas não excedam determinados limites [1].

O controle da qualidade de medicamentos pode ser definido como o conjunto de medidas destinadas a verificar a qualidade de cada lote de medicamentos, para que satisfaçam às normas de atividade, pureza, eficácia e inocuidade [2].

A Legislação específica que trata de controle da qualidade de medicamentos, consta da Resolução da Diretoria Colegiada(RDC) 17 de 16 de abril de 2010 da Agência Nacional de Vigilância Sanitária (ANVISA), capítulo XVII, como se verifica:

Art. 281. O Controle da Qualidade é responsável pelas atividades referentes à amostragem, às especificações e aos ensaios, bem como à organização, à documentação e aos procedimentos de liberação que garantam que os ensaios sejam executados e que os materiais e os produtos terminados não sejam aprovados até que a sua qualidade tenha sido julgada satisfatória.

Parágrafo único. O Controle da Qualidade não deve resumir-se às operações laboratoriais, deve participar e ser envolvido em todas as decisões que possam estar relacionadas à qualidade do produto.

Art. 282. A independência do controle da qualidade em relação à produção é fundamental.

A preocupação com relação à qualidade dos medicamentos no comércio internacional obteve dimensão global após o estabelecimento da Organização Mundial da Saúde (OMS) em 1948. Em 1951, o Comitê Executivo da OMS adotou a resolução $\mathrm{EB}^{1} 7 . \mathrm{R} 79$, que solicitava ao Diretor Geral que considerasse as vantagens de métodos mais uniformes para controle de medicamentos nos países, visando aos interesses da saúde e do comércio internacionais[3].

O uso de medicamentos com desvios de qualidade pode resultar em pacientes que não recebem a quantidade necessária de princípio ativo e, consequentemente, suas enfermidades podem não estar sendo tratadas. A situação piora quando os produtos são adulterados ou deliberadamente formulados utilizando substâncias industriais tóxicas, que não podem ser usadas na fabricação de medicamentos[4], causando danos ainda mais sérios.

\footnotetext{
${ }^{1} \mathrm{~EB}$, do inglês ExecutiveBoard (Comitê Executivo).
} 
No presente projeto de pesquisa, destaca-se a caracterização de impurezas presentes nos fármacos e medicamentos, as quais podem comprometer a qualidade dos mesmos. Para esta caracterização, será feita a descrição das principais metodologias analíticas empregadas na identificação e quantificação destas impurezas. Há também o objetivo de estender as pesquisas para o controle microbiológico destes medicamentos para efeito de uma análise mais completa da qualidade dos mesmos.

O laboratório de controle da qualidade exerce uma das mais importantes funções na produção e controle farmacêuticos. Uma porção significativa da regulação das boas práticas de controle farmacêuticos trata do laboratório de controle da qualidade e testes de produção. Conceitos similares aplicam-se à maior parte dos fármacos [31].

Quanto à qualidade, ela será alcançada desde que exista um bom projeto para a fabricação do medicamento, ou seja, sua formulação seja bem definida: composição, tamanho de lote, equipamentos utilizados, área física compatível com o processo de fabricação, controles das etapas críticas do processo através do cumprimento das Boas Práticas de Fabricação. Com relação à racionalidade do uso, é fundamental que sejam estabelecidas estratégias de distribuição, promoção e venda que assegurem ao consumidor a disponibilidade oportuna dos medicamentos que realmente necessita e que não seja induzido ao uso indiscriminado e irracional dos mesmos. Para a operacionalização desse sistema são necessários alguns componentes, entre eles, a legislação farmacêutica; que deve ser revista periodicamente com o objetivo de acompanhar os avanços científicos e tecnológicos nesta área [32].

Boas Práticasde Fabricação (BPF) é a parte da garantia da qualidade que assegura que produtos sejam consistentemente produzidos e controlados nos padrões de qualidade apropriados para o uso pretendido e requerido pelo seu objetivo comercial. O objetivo primário das BPF é minimizar os ricos de qualquer produção farmacêutica, os quais podem ser classificados, no seu sentido mais amplo, em dois grandes grupos: Contaminação cruzada/ e falsa rotulagem (Suíça, 2003)[23].

A RDC n 33 de 19 abril de 2000, da Agência Nacional de Vigilância Sanitária, determinava que o controle da qualidade e a implantação das Boas Práticas de Manipulação (BPM) fossem ferramentas imprescindíveis para a garantia da 
qualidade dos produtos e serviços. As BPM estabelecem os requisitos gerais para a aquisição de fármacos, insumos farmacêuticos, material de embalagem e armazenamento, a conservação, o transporte, a dispensação, as formulações magistrais e oficiais e fracionamento de produtos industrializados [51].

Para assegurar altos padrões de qualidade para os produtos farmacêuticos, a FoodandDrugAdministration (FDA) reforça a adesão aos requisitos das regulamentações das Boas Práticas de Fabricação. As primeiras regulamentações BPF foram promulgadas em 1963, revisadas em 1978 e têm sido atualizadas periodicamente. A obediência aos padrões BPF é a maior garantia de que os produtos dispensados pelo farmacêutico têm alta qualidade de modo uniforme [24].

Consultando a legislação específica de Boas Práticas de Fabricação, capítulo Il da Resolução da Diretoria Colegiada - RDC 17, de 16 de abril de 2010 da Agência Nacional de Vigilância Sanitária [2], relacionado com as Boas Práticas de Fabricação de medicamentos, tem-se que:

Art. 13. Boas Práticas de Fabricação é a parte da Garantia da Qualidade que assegura que os produtos são consistentemente produzidos e controlados, com padrões de qualidade apropriados para o uso pretendido e requerido pelo registro.

$\S 1^{\circ} \mathrm{O}$ cumprimento das BPF está orientado primeiramente à diminuição dos riscos inerentes a qualquer produção farmacêutica, os quais não podem ser detectados somente pela realização de ensaios nos produtos terminados.

$\S 2^{\circ}$ Os riscos são constituídos essencialmente por contaminação- cruzada, contaminação por partículas, troca ou mistura de produto.

$\S 3^{\circ}$ As BPF determinam que:

I - todos os processos de fabricação devam ser claramente definidos e sistematicamente revisados em função da experiência adquirida. Além disso, devem ser capazes de fabricar medicamentos dentro dos padrões de qualidade exigidos, atendendo às respectivas especificações;

II - sejam realizadas as qualificações e validações necessárias;

III - sejam fornecidos todos os recursos necessários, incluindo:

a) pessoal qualificado e devidamente treinado;

b) instalações e espaço adequados e identificados;

c) equipamentos, sistemas computadorizados e serviços adequados;

d) materiais, recipientes e rótulos apropriados;

e) procedimentos e instruções aprovados e vigentes; 
f) armazenamento e transporte adequados; e

g) instalações, equipamentos e pessoal qualificado para controle em processo.

Os termos comuns utilizados para os padrões de boas práticas de fabricação e no processo de validação, de acordo com a referida RDC 17/2010 da ANVISA, são definidos como segue:

I - ação corretiva: ação adotada para eliminar a causa de uma não conformidade detectada ou outra situação indesejável;

II - ação preventiva: ação adotada para eliminar a causa de uma potencial não conformidade ou outra potencial situação indesejável;

III - ajuste: operação destinada a fazer com que um instrumento de medição tenha desempenho compatível com o seu uso;

IV - amostras de referencia: amostras de matérias-primas e de produtos terminados mantidas pelo fabricante, devidamente identificadas, por um período definido. A quantidade de amostra deve ter pelo menos o dobro da quantidade necessária para efetuar todas as análises previstas;

V - amostra representativa: quantidade de amostra estatisticamente calculada, representativa do universo amostrado, tomada para fins de analise para liberação do lote de material ou produto;

VI - antecâmara: espaço fechado com duas ou mais portas, interposto entre duas ou mais áreas de classes de limpeza distintas, com o objetivo de controlar 0 fluxo de ar entre ambas, quando precisarem ser adentradas. A antecâmara e projetada de forma a ser utilizada para pessoas, materiais ou equipamentos;

VII - área: espaço físico delimitado, onde são realizadas operações sobre condições ambientais especificas;

VIII - área limpa: área com controle ambiental definido em termos de contaminação por partículas viáveis e não viáveis, projetada, construída e utilizada de forma a reduzir a introdução, geração e retenção de contaminantes em seu interior;

IX - área segregada: instalações que oferecem separação completa e total de todos os aspectos de uma operação, incluindo movimentação de pessoal e equipamentos, com procedimentos, controles e monitoramento bem estabelecidos. 
Pode incluir barreiras físicas bem como sistemas de ar separados, mas não necessariamente implica em prédios distintos;

$X$ - calibração: conjunto de operações que estabelece, sob condições especificadas, a relação entre os valores indicados por um instrumento ou sistema de medição ou valores representados por uma medida materializada ou um material de referencia, e os valores correspondentes das grandezas estabelecidos por padrões;

XI - contaminação: a introdução não desejada de impurezas de natureza química ou microbiológica, ou de matéria estranha, em matéria-prima, produto intermediário e/ou produto terminado durante as etapas de amostragem, produção, embalagem ou reembalagem, armazenamento ou transporte;

XII - contaminação cruzada: contaminação de determinada matéria-prima, produto intermediário, produto a granel ou produto terminado por outra matériaprima, produto intermediário, produto a granel ou produto terminado, durante 0 processo de produção;

XIII - controle em processo: verificações realizadas durante a produção de forma a monitorar e, se necessário, ajustar o processo para garantir que o produto se mantenha conforme suas especificações. O controle do ambiente ou dos equipamentos também pode ser considerado como parte do controle em processo;

XIV - critério de aceitação: critério que estabelece os limites de aceitação de especificações de matérias-primas, produtos ou processos/sistemas;

$\mathrm{XV}$ - data de validade: data estabelecida nas embalagens de medicamentos (usualmente em rótulos) até a qual se espera que o produto permaneça dentro das especificações, desde que armazenado corretamente. Essa data e estabelecida por lote, somando-se o prazo de validade a data de fabricação;

XVI - data de reteste: data estabelecida pelo fabricante do insumo, baseada em estudos de estabilidade, após a qual o material deve ser reanalisado para garantir que ainda esta adequado para uso mediato, conforme testes indicativos de estabilidade definidos pelo fabricante do insumo e mantidas as condições de armazenamento pré-estabelecidas. A data de reteste somente e aplicável quando o prazo de validade não foi estabelecido pelo fabricante do insumo;

XVIII - desvio de qualidade: afastamento dos parâmetros de qualidade estabelecidos para um produto ou processo: 
XIX - documentação de lote: todos os documentos associados a fabricação de um lote de produto a granel ou produto terminado. Fornecem um histórico de cada lote de produto e de todas as circunstancias pertinentes a qualidade do produto final;

$X X I$ - embalagem: todas as operações, incluindo o envase e a rotulagem, pelas quais o produto a granel deve passar, a fim de tornar-se produto terminado. Normalmente, o envase de produtos estéreis não e considerado parte do processo de embalagem, visto que esses em sua embalagem primária são considerados produtos a granel;

XXII - especificação: documento que descreve em detalhes os requisitos que os materiais utilizados durante a fabricação, produtos intermediários ou produtos terminados devem cumprir. As especificações servem como base para a avaliação da qualidade;

XXIII - fabricação: todas as operações envolvidas no preparo de determinado medicamento, incluindo a aquisição de materiais, produção, controle da qualidade, liberação, estocagem, expedição de produtos terminados e os controles relacionados;

XXIV - fabricante: detentor da Autorização de Funcionamento para fabricação de medicamentos, expedida pelo órgão competente do Ministério da Saúde, conforme previsto na legislação sanitária vigente;

XXV - formula-mestra/fórmula-padrão: documento ou grupo de documentos que especificam as matérias-primas e os materiais de embalagem com as suas respectivas quantidades, juntamente com a descrição dos procedimentos e precauções necessárias para a produção de determinada quantidade de produto terminado. Além disso, fornece instruções sobre o processamento, inclusive sobre os controles em processo;

XXVI - insumo farmacêutico ativo: qualquer substância introduzida na formulação de uma forma farmacêutica que, quando administrada em um paciente, atua como ingrediente ativo. Tais substâncias podem exercer atividade farmacológica ou outro efeito direto no diagnostico, cura, tratamento ou prevenção de uma doença, podendo ainda afetar a estrutura e funcionamento do organismo humano;

XXVII - instalação: espaço físico delimitado acrescido das máquinas, aparelhos, equipamentos e sistemas auxiliares utilizados para executar os processos; 
XXVIII - lote: quantidade definida de matéria-prima, material de embalagem ou produto processado em um ou mais processos, cuja característica essencial e a homogeneidade. Às vezes pode ser necessário dividir um lote em sub-lotes, que serão depois agrupados para formar um lote final homogêneo. Em fabricação continua, o lote deve corresponder a uma fração definida da produção, caracterizada pela homogeneidade;

$X X X$ - material de embalagem: qualquer material, incluindo material impresso, empregado na embalagem de um medicamento. Exclui-se dessa definição outra embalagem utilizada para transporte ou expedição. Os materiais de embalagem são classificados como primários ou secundários, de acordo com o grau de contato com o produto;

XXXI - matéria-prima: qualquer substância, seja ela ativa ou inativa, com especificação definida, utilizada na produção de medicamentos. Exclui-se dessa definição os materiais de embalagem;

XXXIII - medicamento: produto farmacêutico, tecnicamente obtido ou elaborado, com finalidade profilática, curativa, paliativa ou para fins de diagnóstico;

XXXVII - numero de lote: combinação definida de números e/ ou letras que identifica de forma única um lote em seus rótulos, documentação de lote, certificados de análise correspondentes, entre outros;

XXXVIII - operação crítica: operação no processo de fabricação que pode afetar a qualidade do medicamento;

XXXIX - ordem de produção: documento ou conjunto de documentos que servem como base para a documentação do lote. Devem ser preenchidos com os dados obtidos durante a produção e que contemple as informações da fórmula mestra/fórmula padrão;

$\mathrm{XL}$ - pessoa designada: profissional capacitado designado pela empresa para a execução de uma determinada atividade;

XLI - pior caso: uma ou mais condições que apresentem as maiores possibilidades de defeito do produto ou do processo, quando comparadas com as condições ideais. Tais condições não necessariamente implicam em desvios no produto ou processo;

XLII - Plano Mestre de Validação (PMV): documento geral que estabelece as estratégias e diretrizes de validação adotadas pelo fabricante. Ele prove informação 
sobre o programa de trabalho de validação, define detalhes, responsabilidades e cronograma para o trabalho a ser realizado;

XLIII - padrão de referência: são exemplares de fármacos, impurezas, produtos de degradação, reagentes, dentre outros, altamente caracterizados e da mais elevada pureza, cujo valor e aceito sem referência a outros padrões;

XLIV - padrão secundário (padrão de trabalho): padrão utilizado na rotina laboratorial, cujo valor é estabelecido por comparação a um padrão de referencia;

XLV - Procedimento Operacional Padrão (POP): procedimento escrito e autorizado que fornece instruções para a realização de operações não necessariamente especificas a um dado produto ou material, mas de natureza geral (por exemplo, operação, manutenção e limpeza de equipamentos; validação; limpeza de instalações e controle ambiental; amostragem e inspeção). Certos procedimentos podem ser usados para suplementar a documentação mestre de produção de lote de um produto especifico;

XLVI - produção: todas as operações envolvidas no preparo de determinado medicamento, desde o recebimento dos materiais do almoxarifado, passando pelo processamento e embalagem, ate a obtenção do produto terminado;

XLVII - produto a granel: qualquer produto que tenha passado por todas as etapas de produção, sem incluir o processo de embalagem. Os produtos estéreis em sua embalagem primária são considerados produto a granel;

XLVIII - produto devolvido: produto terminado, expedido e comercializado, devolvido ao fabricante;

XLIX - produto intermediário: produto parcialmente processado que deve ser submetido a etapas subsequentes de fabricação antes de se tornar um produto a granel;

$\mathrm{L}$ - produto terminado: produto que tenha passado por todas as etapas de produção, incluindo rotulagem e embalagem final;

LI - Protocolo (ou Plano) de Validação (PV): documento que descreve as atividades a serem realizadas na validação de um projeto específico, incluindo o cronograma, responsabilidades e os critérios de aceitação para a aprovação de um processo produtivo, procedimento de limpeza, método analítico, sistema computadorizado ou parte destes para uso na rotina;

LII - qualificação: conjunto de ações realizadas para atestar e documentar que quaisquer instalações, sistemas e equipamentos estão propriamente instalados e/ou 
funcionam corretamente e levam aos resultados esperados. A qualificação e frequentemente uma parte da validação, mas as etapas individuais de qualificação não constituem, sozinhas, uma validação de processo;

LIII - Qualificação de Desempenho (QD): verificação documentada que o equipamento ou sistema apresenta desempenho consistente e reprodutível, de acordo com parâmetros e especificações definidas, por períodos prolongados. Em determinados casos, o termo "validação de processo" também pode ser utilizado;

LIV - Qualificação de Instalação (QI): conjunto de operações realizadas para assegurar que as instalações (tais como equipamentos, infra-estrutura, instrumentos de medição, utilidades e áreas de fabricação) utilizadas nos processos produtivos e ou em sistemas computadorizados estão selecionados apropriadamente e corretamente instalados de acordo com as especificações estabelecidas;

LV - Qualificação de Operação (QO): conjunto de operações que estabelece, sob condições especificadas, que o sistema ou subsistema opera conforme previsto, em todas as faixas operacionais consideradas. Todos os equipamentos utilizados na execução dos testes devem ser identificados e calibrados antes de serem usados;

LVI - Qualificação de Projeto (QP): evidencia documentada que as instalações, sistemas de suporte, utilidades, equipamentos e processos foram desenhados de acordo com os requisitos de BPF;

LVII - quarentena: retenção temporária de matérias-primas, materiais de embalagem, produtos intermediários, a granel ou terminados. Esses devem ser mantidos isolados fisicamente ou por outros meios eficazes, enquanto aguardam uma decisão sobre sua liberação, rejeição ou reprocessamento;

LVIII - reanálise: análise realizada em matéria-prima, previamente analisada e aprovada, para confirmar a manutenção das especificações estabelecidas pelo fabricante, dentro do seu prazo de validade;

LIX - reconciliação: comparação entre a quantidade teórica e real nas diferentes etapas de produção de um lote de produto;

LX - recuperação: incorporação total ou parcial de lotes anteriores de qualidade comprovada a outro lote, em uma etapa definida da produção;

LXI - Relatório de Validação (RV): documento no qual os registros, resultados e avaliação de um programa de validação são consolidados e sumarizados. Pode também conter propostas de melhorias; 
LXII - remessa ou entrega: a quantidade de um determinado material fornecida em resposta a uma ordem de compra. Uma única remessa pode incluir um ou mais volumes e materiais pertencentes a mais de um lote;

LXIII - reprocesso: repetição de uma ou mais etapas que já fazem parte do processo de fabricação estabelecido em um lote que não atende as especificações;

LXIV - responsável técnico: a pessoa reconhecida pela autoridade regulatória nacional como tendo a responsabilidade de garantir que cada lote de produto terminado tenha sido fabricado, testado e aprovado para liberação em consonância com as leis e normas em vigor no país;

LXV - revalidação: repetição parcial ou total das validações de processo, de limpeza ou de método analítico para assegurar que esses continuam cumprindo com os requisitos estabelecidos;

LXVI - sistemas computadorizados: ampla escala de sistemas incluindo, mas não limitados a equipamento de fabricação automatizado, equipamento de laboratório automatizado, controle de processo, processo analítico, execução de fabricação, gerenciamento das informações de laboratório, planejamento dos recursos de fabricação e sistemas de gerenciamento de documentos e monitoramento. Um sistema computadorizado e formado por hardware, software e componentes de rede, somados as funções controladas e documentação relacionada;

LXVII - Solução Parenteral de Grande Volume (SPGV): solução estéril e apirogênica, destinada a aplicação parenteral em dose única, cujo volume e de $100 \mathrm{~mL}$ ou superior. Estão incluídas nesta definição as soluções para irrigação e soluções para diálise peritoneal;

LXVIII - validação: ato documentado que atesta que qualquer procedimento, processo, equipamento, material, atividade ou sistema realmente $\mathrm{e}$ consistentemente leva aos resultados esperados;

LXIX - validação concorrente: validação realizada durante a rotina de produção de produtos destinados a venda;

LXX - validação de limpeza: evidência documentada que demonstre que os procedimentos de limpeza removem resíduos a níveis pré-determinados de aceitação, levando em consideração fatores tais como tamanho do lote, dosagem, dados toxicológicos, solubilidade e área de contato do equipamento com o produto; 
LXXI - Validação de Processo (VP): evidência documentada que atesta com um alto grau de segurança que um processo específico produzira um produto de forma consistente, que cumpra com as especificações pré-definidas e características de qualidade;

LXXII - validação de sistemas computadorizados: evidência documentada que atesta com um alto grau de segurança que uma analise de sistema computadorizado, controles e registros são realizados corretamente e que o processamento dos dados cumpre com especificações pré-determinadas;

LXXIII - validação prospectiva: validação realizada durante o estágio de desenvolvimento do produto, com base em uma análise de risco do processo produtivo, o qual e detalhado em passos individuais; estes por sua vez, são avaliados com base em experiências para determinar se podem ocasionar situações críticas; e

LXXIV - validação retrospectiva: envolve a avaliação da experiência passada de produção, sob a condição de que a composição, procedimentos e equipamentos permanecem inalterados.

Em muitos países, a qualidade de produtos farmacêuticos fabricados industrialmente é garantida fundamentalmente por meio de sistemas de licenciamento e inspeção e pela aplicação de BPF (OMS, 2005)[3].

Até pouco tempo, controles analíticos no sistema de distribuição de fármacos e medicamentos eram considerados meramente suplementares. A qualidade da investigação realizada após o licenciamento/autorização era considerada uma forma de detectar:

- Qualquer erro não intencional na fabricação de medicamentos por meio de procedimentos legítimos;

- Qualquer degradação que pudesse ocorrer no curso da distribuição normal.

Uma vez que tais eventos eram considerados pouco frequentes, raramente eram recomendadas amostragens de maior porte (OMS, 2005)[3].

Para assegurar a qualidade dos medicamentos, as impurezas devem se monitoradas cuidadosamente. É importante entender o que constitui uma impureza e identificar potenciais fontes de cada impureza. Métodos analíticos selecionados precisam ser desenvolvidos para monitorar as impurezas. Geralmente, é desejável 
caracterizar as impurezas para fornecer um critério para fins comparativos. Novas impurezas podem evidenciar como mudanças devem ocorrer na síntese, formulação, ou procedimentos de produção,ainda que para melhorá-los. Às vezes, é necessário isolar e caracterizar uma impureza quando métodos acoplados não fornecem a estrutura ou quando a confirmação é necessária com um material autêntico de referência. A avaliação de um material autêntico pode permitir também estudos toxicológicos e promover um padrão de monitoramento de rotina para os medicamentos.

As impurezas inorgânicas são, geralmente, decorrentes do processamento da matéria-prima ou produto, e os ensaios de pureza são associados com a frequência e/ou relevância do contaminante. Entre os contaminantes inorgânicos mais comuns, destacam-se a água, íons metálicos, cloretos, sulfatos e outros ânions.

A tabela abaixo apresenta os ensaios de pureza constante na Farmacopeia Brasileira [5].

Tabela 1 - Ensaios de pureza constante na Farmacopeia Brasileira

\begin{tabular}{lcl}
\hline \multicolumn{1}{c}{ Ensaio } & Tipo & \multicolumn{1}{c}{ Relevância } \\
Teor de Umidade & Q & Dosagem e estabilidade \\
Substânciasvoláteis/nãovoláteis & Q & Parâmetroqualitativo \\
Cinzas & Q & ParâmetroQualitativo \\
CinzasSulfatadas & Q & ParâmetroQualitativo \\
CinzasinsolúveisemHCl & Q & ParâmetroQualitativo \\
Substânciassolúveis/insolúveis & Q & ParâmetroQualitativo \\
Metaispesados & S & Toxicicidade e estabilidade \\
Ferro & $\mathrm{S}$ & Estabilidade \\
Cloretos & $\mathrm{S}$ & Estabilidade \\
Sulfatos & $\mathrm{S}$ & Estabilidade \\
Arsênio & $\mathrm{S}$ & Toxicicidade \\
Amônia & $\mathrm{S}$ & Toxicidade e estabilidade \\
\hline
\end{tabular}

Fonte:GIL, 2010.

$\mathrm{Q}=$ quantitativo; $\mathrm{S}=$ semiquantitativo

Os métodos quantitativos oficiais para determinação de impurezas são, essencialmente, ensaios gravimétricos. Sendo as únicas exceções, entre os métodos gerais de pureza da Farmacopeia Brasileira (4⿳亠丷a edição), os métodos aquamétricos Karl Fisher e destilação azeotrópica. 
Os ensaios semiquantitativos são baseados em reações químicas, as quais produzem turbidez ou mudança de cor visualmente detectável.

Além dos métodos farmacopeicos, outros podem ser empregados, desde que validados, no controle de qualidade em ensaios de pureza. A pureza da água é facilmente estimada pela sua condutividade iônica.

A absorção atômica é empregada para análise de metais pesados e apresenta a vantagem de ser mais sensível e precisa, assegurando determinações quantitativas de diferentes íons metálicos.

Outros métodos quantitativos aplicados a impurezas inorgânicas incluem o High Performance/Pressure Liquide Chromatography(HPLC) de troca iônica com detector eletroquímico e métodos potenciométricos baseados em sensores íons seletivos.

As impurezas orgânicas em insumos farmacêuticos decorrem de variadas formas de contaminação. Basicamente, podem ser divididas em intrínsecas ou extrínsecas. As impurezas intrínsecas são decorrentes de processos de decomposição (ex.Ácido AcetilSalicílico-AAS em ácido salicílico e ácido acético). As extrínsecas decorrem de contaminação ambiental ou falhas em processos de obtenção do produto.

Os profissionais da química analítica têm como desafio 0 isolamento de espécies presentes em determinados compostos. Considerando que as espécies em pesquisa podem ser subprodutos ou impurezas que podem ter complexidade de cadeia carbônica e grupos funcionais, a exigência para as técnicas de identificação e separação é cada vez maior[53].

As técnicas de separação cromatografia líquida de alta eficiência(CLAE) e cromatografia em camada delagada(CCD) são de longe as mais aplicadas, mas também são utilizados os métodos eletroanalíticos, calorimétricos e alguns ensaios clássicos.

Além destes, também são utilizados métodos que determinam a faixa de fusão por técnicas calorimétricas- análise térmica diferencial(DTA), análise termogravimétrica diferencial(DTG), calorimetria exploratória diferencial(DSC), bem como a rotação óptica e a determinação de pH. 


\section{OBJETIVOS}

\subsection{OBJETIVOS GERAIS}

- Desenvolver e validar métodos para o controle da qualidade de medicamentos e insumos farmacêuticos.

Neste tópico, os estudos irão concentrar-se na detecção de possíveis impurezas nas soluções medicamentosas da bupivacaína, devendo se estender os estudos para a análise microbiológica da qualidade deste medicamento na sua forma injetável. Com relação às metodologias adotadas nas análises dos medicamentos, dar-se-á maior destaque Cromatografia Líquida de Alta Eficiência;

- Realizar estudos de estabilidade de medicamentos e processos de degradação;

- Aplicar diretamente os conhecimentos adquiridos durante a pós-graduação nas atividades de regulação da Anvisa.

\subsection{OBJETIVOS ESPECÍFICOS}

- Desenvolver e validar métodos para o controle de qualidade do cloridrato de bupivacaína injetável;

- Desenvolver e validar metodologias indicadoras de estabilidade para a determinação do cloridrato de bupivacaina em medicamentos injetáveis. 


\section{REVISÃO DE LITERATURA}

\subsection{CLORIDRATO DE BUPIVACAÍNA INJETÁVEL}

\subsubsection{Características físico-químicas}

a) Fórmulaestrutural<smiles>CCCCN1CCCCC1C(=O)Nc1c(C)cccc1C</smiles>

Figura 1 - Formula estrutural do cloridrato de bupivacaína

b) Fórmula molecular

$\mathrm{C}_{18} \mathrm{H}_{28} \mathrm{~N}_{2} \mathrm{O} . \mathrm{HCl}$

c) Caracteresfísicos

Pócristalinobranco, inodoro

d) Constantesfísico-químicas

Ponto de fusão: funde a $254^{\circ} \mathrm{C}$, com decomposição.Peso Molecular:324.89

e) CAS

14252-80-3[8].

É usada na forma de cloridrato, pó cristalino branco, solúvel em água. É 4 vezes mais potente que a lidocaína. A bupivacaína injetável deve ser usada exclusivamente por especialistas[54]. Em concentrações de $5 \mathrm{mg} / \mathrm{mL}$ ou $7,5 \mathrm{mg} / \mathrm{mL}$ tem longa duração de ação, de 2-5 horas após uma única injeção epidural, e até 12 horas, após bloqueios nervosos periféricos. O início do bloqueio é mais lento do que com a lidocaína, especialmente quando na anestesia de nervos grandes. Quando usada em baixas concentrações $(2,5 \mathrm{mg} / \mathrm{mL}$ ou menos) há um menor efeito nas fibras de nervos motores, e a duração da ação é menor. Entretanto,baixas concentrações podem ser usadas com vantagem para o alívio prolongado da dor, 
por exemplo, no parto ou no pós-operatório. A adição de um vasoconstritor, como epinefrina, pode diminuir a velocidade de absorção.

\subsubsection{Propriedades farmacodinâmicas}

O cloridrato de bupivacaína, como outros anestésicos locais, causa um bloqueio reversível da propagação do impulso ao longo das fibras nervosas através da inibição do movimento de íonssódio para dentro das membranas nervosas. Presume-se que anestésicos locais do tipo amida atuem dentro dos canais de sódio das membranas nervosas. Anestésicos locais podem ter efeitos similares em membranas excitáveis no cérebro e no miocárdio. Se quantidades excessivas do fármaco alcançarem rapidamente a circulação sistêmica, aparecerão sinais e sintomas de toxicidade,originados principalmente dos sistemas nervoso central e cardiovascular. A toxicidade no sistema nervoso central (ver item superdosagem) geralmente precede os efeitos cardiovasculares, uma vez que ela ocorre em níveis plasmáticos mais baixos. Os efeitos diretos dos anestésicos locais no coração incluem condução lenta, inotropismo negativo e, consequentemente, parada cardíaca. Os efeitos cardiovasculares indiretos (hipotensão, bradicardia) podem ocorrer após administração epidural ou espinhal, dependendo da extensão do bloqueio simpático concomitante [9].

\subsubsection{Propriedades farmacocinéticas}

O cloridrato de bupivacaína tem um pKa de 8,1 e é mais lipossolúvel que a lidocaína. A solubilidade do cloridrato de bupivacaína é limitada em $\mathrm{pH}<6,5$. Isto deve ser levado em consideração quando soluções alcalinas, como carbonato, são adicionadas, pois podem ocorrer precipitações. A velocidade de absorção sistêmica depende da dose, da via de administração e da vascularização do local da injeção. O bloqueio intercostal proporciona o maior pico de concentração plasmática, devido à rápida absorção (concentração plasmática máxima na ordem de 1-4 mg/L após uma dose de $400 \mathrm{mg}$ ), enquanto injeções abdominais subcutâneas resultam na maior concentração plasmática. Bloqueios de plexo maiores e bloqueios epidurais são intermediários. Em crianças, absorção rápida e altas concentrações plasmáticas (na ordem de 1-1,5 mg/l após uma dose de 3mg/Kg ) são observadas com bloqueio 
caudal. A absorção pode ser retratada pela adição de epinefrina. O cloridrato de bupivacaína mostra absorção completa e bifásica do espaço epidural com meia-vida na ordem de 7 min e 6 horas, respectivamente. A absorção lenta é fator limitante na eliminação do cloridrato de bupivacaína, o que explica porque a meia-vida de eliminação aparente após administração epidural é maior do que após administração intravenosa. O cloridrato de bupivacaína tem clearance plasmático total de 0,58 $\mathrm{L} / \mathrm{min}$, um volume de distribuição no estado de equilíbrio de $73 \mathrm{~L}$, uma meia-vida de eliminação de 2,7 horas e uma taxa de extração hepática intermediária de 0,40. No plasma, o cloridrato de bupivacaína liga-se principalmente à alfa-1-glicoproteína ácida com taxa de ligação plasmática de $96 \%$. A meia-vida de eliminação terminal é prolongada no recém-nascido em até 8 horas. Em crianças, acima de 3 meses, a meia-vida de eliminação é similar a dos adultos. Um aumento na concentração de alfa-1-glicoproteína ácida, que ocorre no pós-operatório de cirurgias maiores, pode causar um aumento na concentração plasmática total de cloridrato de bupivacaína. O nível de fármaco livre permanecerá o mesmo. Isto explica porque as concentrações plasmáticas totais acima do nível limiar tóxico aparente de 2,6-3,0 $\mathrm{mg} / \mathrm{L}$ são bem toleradas. O cloridrato de bupivacaína atravessa prontamente a placenta e o equilíbrio em relação ao fármaco livre será alcançado. A taxa de ligação plasmática no feto é menor que a da mãe,o que resulta em concentração plasmática mais baixa no feto do que na mãe. Entretanto, a concentração de fármaco livre é igual na mãe e no feto. O cloridrato de bupivacaína está presente noleite materno em concentrações menores que as concentrações no plasma materno. Cerca de 6\% do cloridrato de bupivacaína é excretado na urina como fármaco inalterado em 24 horas, e aproximadamente $5 \%$ como o metabólito $\mathrm{N}$-dealquilado, pipecolilxilidina (PPX). Após administração epidural, a recuperação urinária de cloridrato de bupivacaína inalterada é de cerca de $0,2 \%$, de PPX é cerca de $1 \%$ e de 4-hidroxibupivacaína é cerca de $0,1 \%$ da dose administrada[9].

\subsection{INDICAÇÕES}

- anestesia por infiltração, quando se deseja longa duração, por exemplo, para analgesia pós operatória; 
- Bloqueios de longa duração ou anestesia peridural onde a epinefrina é contra-indicada eo relaxamento muscular potente não é necessário ou desejável. Anestesia em obstetrícia [9].

\subsection{DESCRIÇÃO E CARACTERIZAÇÃO DAS IMPUREZAS}

As principais impurezas, as quais podem estar presentes nas preparações contendo lidocaína, bupivacaína, mepivacaína, prilocaína ou ropivacaína são 2,6dimetilanilina (2,6-DMA) e o-toluidine (o-TLD). Estas impurezas podem ser formadas durante a síntese destes anestésicos locais ou durante a estocagem das preparações [13].

2,6-Dimetilanilina e o-toluidina podem ser potenciais impurezas tecnológicas porque elas são usadas como substratos na síntese destes fármacos. Além disso, elas podem também aparecer como produtos de decomposição durante a estocagem dos medicamentos. 2,6-Dimetilanilina também demonstrou atividade anestésica, mas é significantemente mais tóxico que o composto de origem. De todos os anestésicos amídicos usados na prática anestésica, prilocaína é o menos tóxico [13].

o-Toluidina(o-TLD) e 2,6 Dimetilanilina(2,6-DMA)

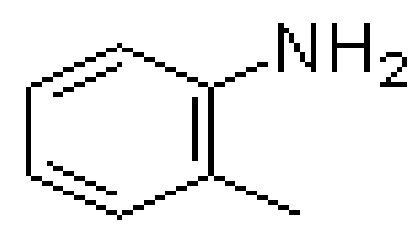

Figura 2 - Fórmula estrutural da o-TLD

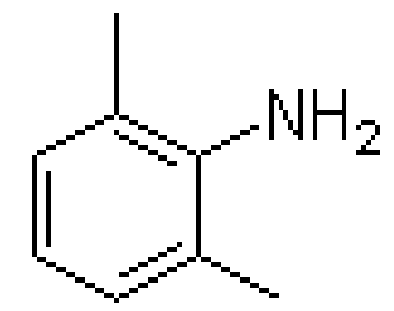

Figura 3 - Fórmula estrutural da 2,6-DMA. 


\subsubsection{Análise dos padrões analíticos das impurezas por cromatografia líquida de alta eficiência}

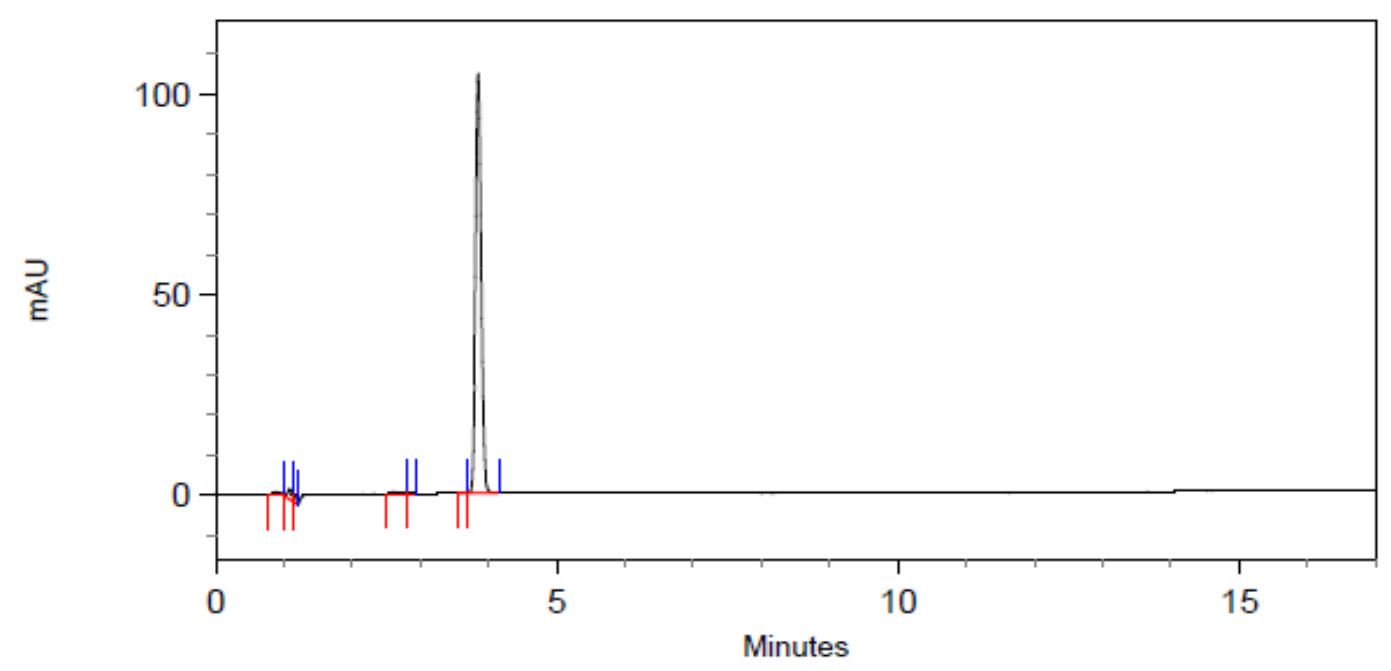

Figura 4 - Cromatograma da solução de 2,6 dimetilanilina5,0 $\mu \mathrm{g} \mathrm{mL}^{-1}$; Condições: Coluna Gemini $C_{18}(5 \mu \mathrm{m}, 150 \times 4,6 \mathrm{~mm})$, vazão: $1,5 \mathrm{~mL} \mathrm{~min}^{-1}$, fase móvel: ACN : Tris Buffer 45:55, $\mathrm{pH}$ 7,9 ajustado com ácido clorídrico 1M; detecção UV de $205 \mathrm{~nm}$.

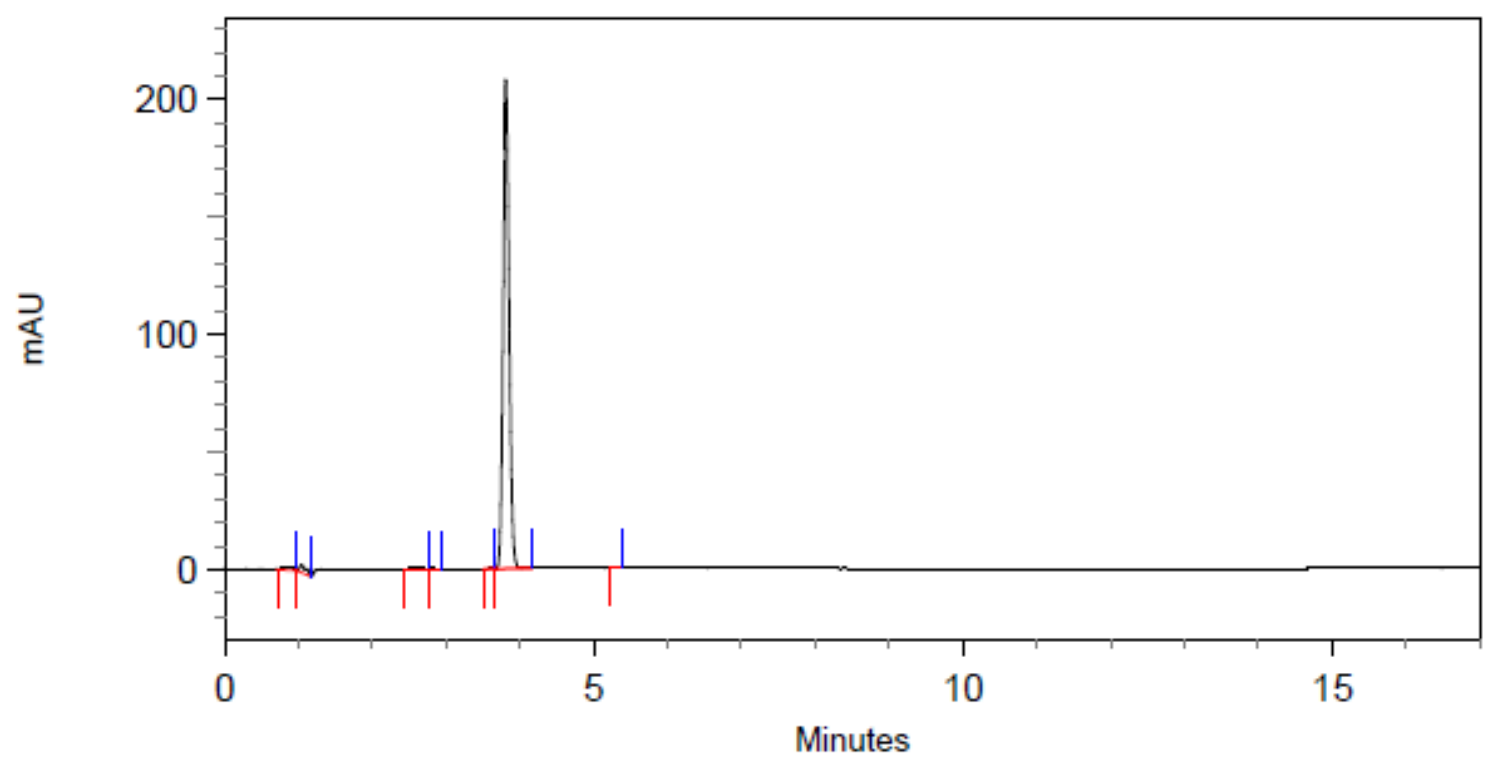

Figura 5 - Cromatograma da solução de 2,6 dimetilanilina $10,0 \mu \mathrm{g} \mathrm{mL}^{-1}$; Condições: Coluna Gemini $C_{18}(5 \mu \mathrm{m}, 150 \times 4,6 \mathrm{~mm})$, vazão: $1,5 \mathrm{~mL} \mathrm{~min}^{-1}$, fase móvel: ACN : Tris Buffer 45:55, pH 7,9 ajustado com ácido clorídrico 1M; detecção UV de $205 \mathrm{~nm}$. 


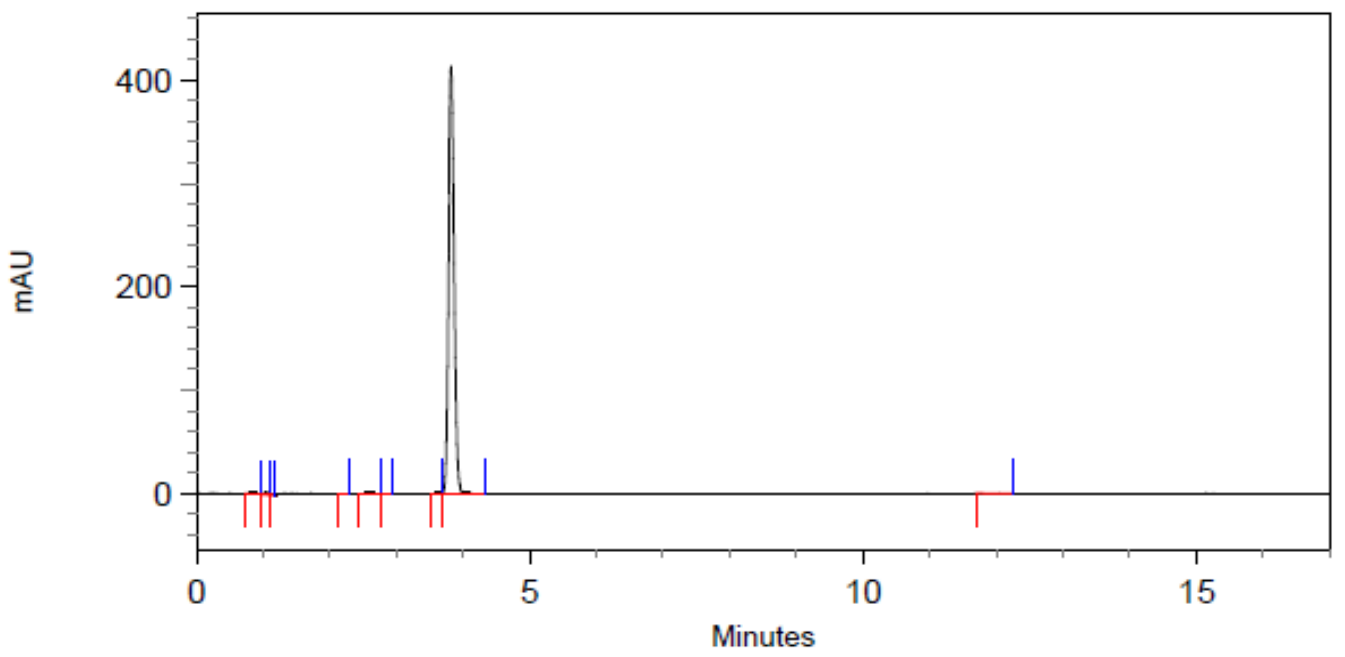

Figura 6 - Cromatograma da solução de 2,6 dimetilanilina $20,0 \mu \mathrm{g} \mathrm{mL}^{-1}$; Condições: Coluna Gemini $\mathrm{C}_{18}(5 \mu \mathrm{m}, 150 \times 4,6 \mathrm{~mm})$, vazão: $1,5 \mathrm{~mL} \mathrm{~min}^{-1}$, fase móvel: ACN : Tris Buffer 45:55, $\mathrm{pH}$ 7,9 ajustado com ácido clorídrico 1M; detecção UV de $205 \mathrm{~nm}$.

Analisando-se os 3 cromatogramas, verfica-se que os tempos de retenção apresentam-se constantes e a resposta do equipamento proporcional às concentrações.

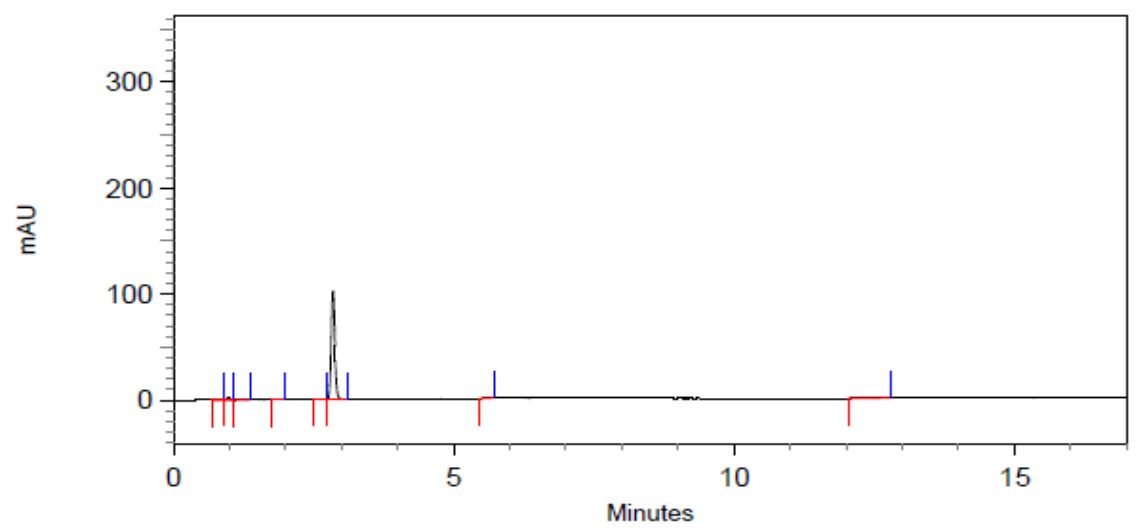

Figura 7 - Cromatograma da solução de o-TLD $5,0 \mu \mathrm{g} \mathrm{mL}^{-1}$; Condições: Coluna Gemini $\mathrm{C}_{18}(5$ $\mu \mathrm{m}, 150 \times 4,6 \mathrm{~mm}$ ), vazão: $1,5 \mathrm{~mL} \mathrm{~min}^{-1}$, fase móvel: ACN : Tris Buffer 45:55, $\mathrm{pH}$ 7,9 ajustado com ácido clorídrico 1M; detecção UV de $205 \mathrm{~nm}$. 


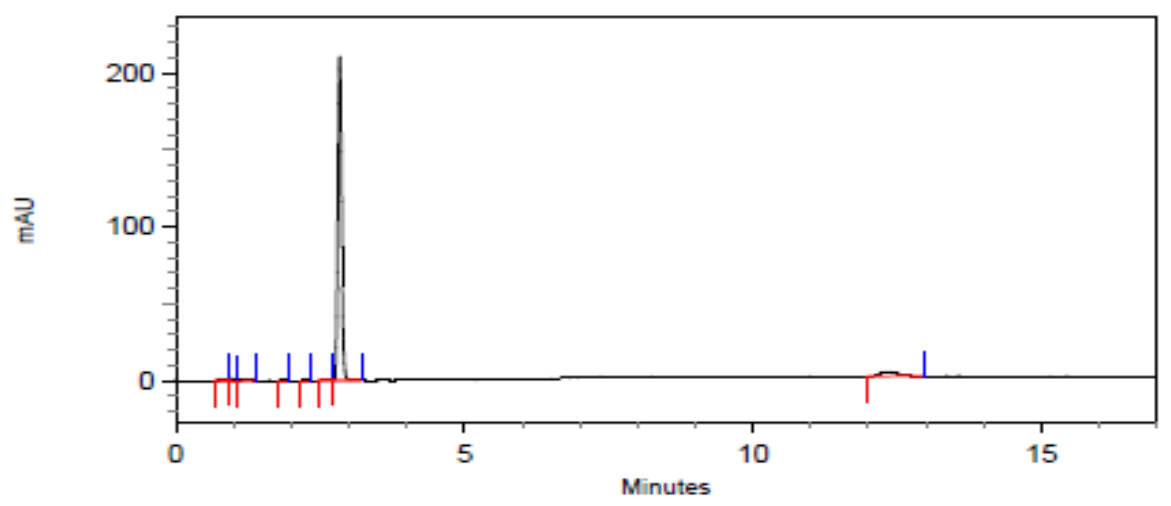

Figura 8 - Cromatograma da solução de o-TLD 10,0 $\mathrm{g} \mathrm{mL}^{-1}$; Condições: Coluna Gemini $\mathrm{C}_{18}(5$ $\mu \mathrm{m}, 150 \times 4,6 \mathrm{~mm}$ ), vazão: $1,5 \mathrm{~mL} \mathrm{~min}^{-1}$, fase móvel: ACN : Tris Buffer 45:55, $\mathrm{pH} \mathrm{7,9}$ ajustado com ácido clorídrico 1M; detecção UV de $205 \mathrm{~nm}$.

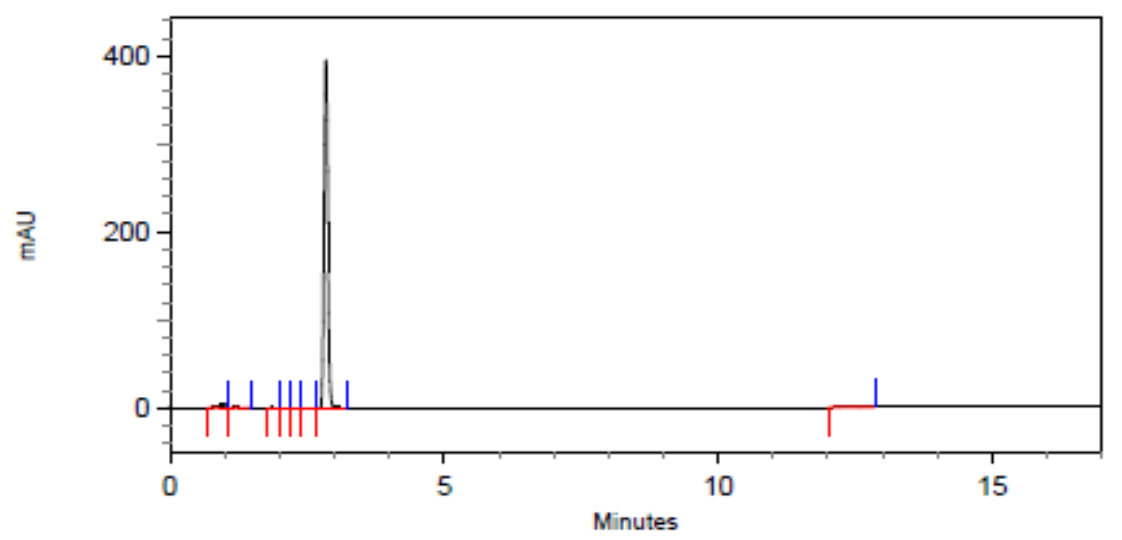

Figura 9 - Cromatograma da solução de o-TLD $5,0 \mu \mathrm{g} \mathrm{mL}^{-1}$; Condições: Coluna Gemini $\mathrm{C}_{18}(5$ $\mu \mathrm{m}, 150 \times 4,6 \mathrm{~mm}$ ), vazão: $1,5 \mathrm{~mL} \mathrm{~min}^{-1}$, fase móvel: $\mathrm{ACN}$ : Tris Buffer 45:55, $\mathrm{pH}$ 7,9 ajustado com ácido clorídrico 1M; detecção UV de $205 \mathrm{~nm}$.

Analogamente à análise do padrão de 2,6 DMA, verfica-se que os tempos de retenção apresentam-se constantes e a resposta do equipamento proporcional às concentrações.

\subsection{TESTES DE ESTABILIDADE}

A estabilidade é definida como a extensão em que um produto retém, dentro dos limites especificados e dentro do período de armazenagem e de uso (isto é, prazo de validade), as mesmas propriedades e características que possuía na ocasião em que foi fabricado [10].

Existem cinco tipos de estabilidade importantes para o farmacêutico: 
1. Química: cada ingrediente ativo retém sua integridade química e potência indicadas na embalagem, dentro dos limites especificados;

2. Física: são mantidas as propriedades físicas originais, inclusive aparência, palatabilidade, uniformidade, dissolução e suspensibilidade;

3. Microbiológica: a esterilidade ou resistência ao crescimento microbiano é mantida, de acordo com os requisitos especificados. Os agentes antimicrobianos presentes mantêm a efetividade dentro dos limites determinados;

4. Terapêutica: o efeito terapêutico permanece inalterado;

5. Toxicológico: não ocorre aumento significante na toxicidade [10].

\subsection{TESTE DE INSTABILIDADE}

A instabilidade das formulações farmacêuticas pode ser detectada em alguns casos por uma mudança na aparência física, na cor, no odor, no gosto ou na textura enquanto em outros casos, podem ocorrer alterações químicas que não são evidentes e que só podem ser verificadas por análise química. Os dados científicos que fazem parte do estudo da estabilidade de uma formulação levam à previsão do prazo de validade esperado para o produto e, quando necessário, a um novo plano para o fármaco (por exemplo, em forma de sal ou éster mais estável) e à reformulação de sua forma farmacêutica. É claro que a velocidade em que a degradação do fármaco ocorre em uma formulação é essencial. O estudo da velocidade da mudança química e do modo como é influenciada por fatores como a concentração do fármaco ou do reagente, o solvente empregado, as condições de temperatura e pressão, e a presença de outros agentes químicos na formulação é denominado cinética da reação [10].

Quando são detectados produtos de degradação química, a Food and Drug Administration exige que o fabricante relate a identidade química, inclusive as estruturas, o mecanismo de formação, as propriedades físicas e químicas, os procedimentos para isolamento e purificação, as especificações e diretrizes para determinação em níveis esperados e a significância biológica dessa presença [10].

As alterações, na estabilidade dos medicamentos são provocadas por fatores, como:

Temperatura; 
* luz;

- umidade;

* gases que compõem o ar atmosférico;

* iinterações entre fármacos;

* interações dos fármacos com os excipientes ou adjuvantes;

* alterações de PH;

* qualidade das embalagens;

* impurezas [11].

\subsection{DEFINIÇÕES}

\subsubsection{Estudos de estabilidade acelerada}

Estudos projetados para acelerar a degradação química ou mudanças físicas de um produto farmacêutico pelo uso de condições de estocagem forçadas. Os dados assim obtidos, juntamente com aqueles derivados dos estudos de longa duração, podem ser usados para avaliar efeitos químicos prolongados em condições não aceleradas e para avaliar o impacto de curtas exposições a condições fora daquelas estabelecidas no rótulo, como podem ocorrer durante o transporte. Os resultados dos estudos acelerados nem sempre são indicativos de mudanças físicas [12].

\subsubsection{Estudos de estabilidade de longa duração}

Estudos projetados para verificação das características físicas, químicas, biológicas e microbiológicas de um produto farmacêutico, durante e depois do prazo de validade esperado. Os resultados são usados para estabelecer ou confirmar a vida média projetada e recomendar as condições de estocagem [12].

\subsubsection{Estudos de estabilidade de acompanhamento}

Estudos realizados para verificar que o produto farmacêutico mantém suas características físicas, químicas, biológicas, e microbiológicas conforme os estudos iniciais realizados [12]. 


\subsubsection{Lote}

Quantidade de um produto obtido em um único processo ou série de processos, cujas características essenciais são a homogeneidade e qualidade dentro dos limites especificados [12].

\subsubsection{Lote em escala piloto}

Um lote de produto farmacêutico produzido por um processo totalmente representativo simulando o lote de produção industrial e estabelecido por uma quantidade mínima equivalente a $10 \%$ do lote industrial previsto, ou quantidade equivalente à capacidade mínima do equipamento industrial a ser utilizado [12].

\subsubsection{Período de utilização}

Período de tempo durante o qual uma preparação reconstituída ou uma forma farmacêutica acabada em recipientes multidose abertos pode ser usada [12].

\subsubsection{Prazo de validade}

Data limite para utilização de um produto farmacêutico definido pelo fabricante, com base nos seus respectivos testes de estabilidade, mantidas as condições de armazenamento e transporte estabelecidas pelo mesmo [12].

\subsubsection{Testes de estabilidade}

Conjunto de testes projetados para obter informações sobre a estabilidade de produtos farmacêuticos visando definir sua vida-média e período de utilização em embalagem e condições de estocagem especificadas [12]. 


\subsubsection{Vida de prateleira}

Período de tempo durante o qual um produto farmacêutico, se estocado corretamente, é esperado manter suas especificações como determinado pelos estudos de estabilidade em um número de lotes de produtos.

A vida-média é usada para estabelecer o prazo de validade de cada produto [12].

Durante a Pós-graduação será explorado prioritariamente os aspectos físicoquímicos da degradação dos medicamentos, e a determinação do prazo de validade, através da realização de diversos testes de estabilidade da forma farmacêutica injetável dos medicamentos a base de bupivacaína.

\subsection{FREQUÊNCIA DOS TESTES}

Estudos acelerados: 0, 1, 2, 3 e 6 meses. Deverão ser realizados todos os testes descritos em monografia específica de cada produto.

Estudos de longa duração: 0, 6, 9 e 12 meses, e anualmente após o primeiro ano até o tempo de vida de prateleira declarado no registro. Deverão ser realizados todos os testes descritos em monografia específica de cada produto.

Para estudos de acompanhamento, as amostras devem ser testadas em intervalos de 6 meses para confirmação da vida de prateleira prevista ou a cada 12 meses para produtos já estabelecidos. Formulações altamente estáveis podem ser testadas após 12 meses e no final da vida de prateleira. Produtos contendo substâncias menos estáveis devem ser testados a cada 3 meses no primeiro ano, cada 6 meses no segundo ano e depois anualmente até o tempo de vida de prateleira estabelecido [12]. 


\section{INTRODUÇÃO DA TÉCNICA DE ANÁLISE}

A invenção e rápida difusão da Cromatografia de Camada Delgada (CCD) e da Cromatografia Líquida de Alta Eficiência (CLAE) nos anos de 1960 e 1970, respectivamente, criaram uma completa nova situação neste campo. As razões para isso são as seguintes:

1) Ambos os métodos são eficientes na detecção, separação, identificação e determinação quantitativa de impurezas orgânicas de forma mais rápida;

2) Os métodos cromatográficos seletivos foram também considerados apropriados para a determinação segura dos principais componentes da amostra [51].

\subsection{CROMATOGRAFIA LÍQUIDA DE ALTA EFICIÊNCIA}

A Cromatografia Líquida de Alta Performance ou Eficiência pode ser conceituada como um método físico químico de separação. É usada em casos em que a amostra a analisar está em solução, sendo os constituintes a serem separados chamados de solutos [53].

A cromatografia líquida de alta eficiência consegue separar misturas que contêm um grande número de compostos similares. Atualmente, seu emprego em vários laboratórios é considerado indispensável por químicos, farmacêuticos, bioquímicos e outros [13].

Esta técnica utiliza instrumentos que podem ser totalmente automatizados. È um tipo de cromatografia líquida que emprega colunas recheadas com materiais especialmente preparados e uma fase móvel, eluída sob altas pressões. Ela tem a capacidade de realizar separações e análises quantitativas de uma grande variedade de compostos presentes em diversos tipos de amostras, em escalas de tempo de poucos minutos, com alta resolução, eficiência e detectibilidade [13].

A Cromatografia Líquida de Alta Eficiência (CLAE ou HPLC) se desenvolveu muito nos últimos anos, recebendo o nome de cromatografia líquida por que a sua fase móvel é um solvente. Os componentes de um cromatógrafo líquido são: bomba, coluna cromatográfica, detector e o registrador. É um método utilizado para separação de espécies iônicas ou macromoléculas e compostos termolábeis. 
A fase móvel da CLAE deve ser um solvente que respeite algumas características impostas por esse método analítico. A principal característica é que a fase móvel dissolva a amostra sem qualquer interação química entre ambas. Esta fase deve ter alto grau de pureza ou ser de fácil purificação, para que se possam fazer análises de alta sensibilidade, pois as impurezas podem interferir na detecção do analito por ultravioleta (UV). A fase móvel deve ser compatível com o detector empregado e, também possuir polaridade adequada para permitir uma separação conveniente dos componentes da amostra. Embora existam vários solventes, três deles são mais utilizados: água, metanol e acetonitrila [14].

Como fase estacionária utiliza-se sólidos ou semirígidos, cujas partículas porosas esféricas ou irregulares apresentam diferentes diâmetros e suportam pressão até 350 bar.

A coluna cromatográfica é feita de um material inerte que resiste a todas as pressões em que ela vai ser usada. A capacidade da coluna é determinada pelo comprimento, diâmetro e pelo material de recheio. As colunas geralmente utilizadas são: octadecil (C18, RP18, ODS), octil (C8, RP8), CN (cianopropil) e NH2 (amina). Quanto aos detectores, não existe um que apresente todas as propriedades para que ele seja ideal para CLAE. Não são versáteis, ou universais, mas existem detectores que apresentam ampla faixa de aplicações. A sensibilidade de um detector é determinada a partir da relação entre o sinal produzido e a quantidade de amostra que gera este sinal. A linearidade é a faixa linear do sistema, onde o sinal do detector é diretamente proporcional à concentração do soluto [6].

Os detectores mais usadas na CLAE são os fotométricos, baseados na absorbância no ultravioleta e no visível. Os detectores de fluorescência, utilizados como método de detecção específica, são sensíveis para substâncias que fluorescem. Este tipo de detector pode detectar quantidades de ordem picograma. Também são utilizados detectores por índice de refração, os quais acompanham continuamente a diferença no índice de refração entre a fase móvel pura e o efluente que sai da coluna contendo os componentes da amostra. A resposta deste detector é moderada, geralmente de ordem micrograma [12]. 


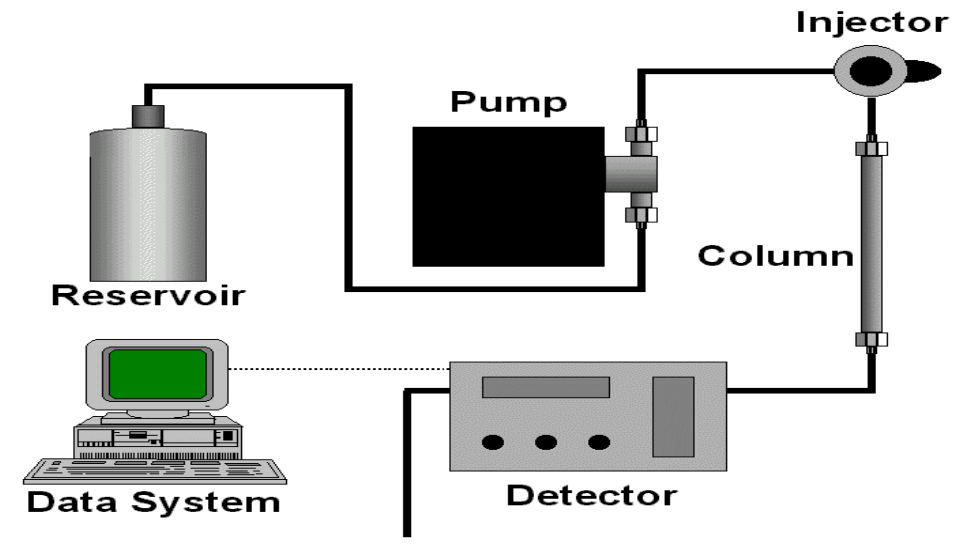

Figura 10 - Esquema de um sistema de CLAE

\subsection{PROCEDIMENTOS EXPERIMENTAIS}

Tendo por base o artigo científico relacionado à detecção e quantificação de impurezas em diversos anestésicos injetáveis, incluindo o Cloridrato de Bupivacaína, iniciou-se os procedimentos experimentais de análise da substância padrão em cromatografia líquida de alta eficiência fornecida gratuitamente pelo laboratório farmacêutico fabricante.

Utilizou-se um equipamento de CLAE no laboratório de química farmacêutica da central analítica da Faculdade de Ciências Farmacêuticas da Universidade de São Paulo (FCF/USP).

\subsubsection{Características principais do CLAE utilizado na pesquisa}

O equipamento utilizado na pesquisa, Marca Shimadzu, software Class VP, caracteriza-se por apresentar sistema de injeção manual das amostras a $10 \mu \mathrm{l}$, detector de Ultra-Violeta-visível e colunaGeminiC ${ }_{18}, 150$ ×4,60 mm.

Procederam-se algumas adaptações com relação a preparação da fase móvel, a mesma ficou composta por $45 \%$ de acetonitrila e $55 \%$ de tampão tris buffer, reduziu-se a proporção de acetonitrila para aumentar o tempo de retenção para melhor visualização do princípio ativo em relação à possíveis impurezas.

O tempo de corrida foi estabelecido em 17 minutos, com vazão de $1,5 \mathrm{ml} / \mathrm{min}$ e comprimento de onda para leitura do detector UV-vis a $205 \mathrm{~nm}$. 


\subsection{ELETROFORESE CAPILAR (CE)}

As técnicas eletroforéticas empregadas em controle da qualidade são a eletroforese em gel e a eletroforese capilar. Ambas as técnicas empregam a aplicação de uma diferença de potencial sobre uma solução ou gel onde se encontra solubilizado $o$ analito. Essa diferença de potencial faz com que os elementos carregados migrem em direção ao polo de carga oposta (migração eletrocinética). Caso o analito esteja carregado, ele poderá migrar sozinho para o eletrodo de carga oposta. Caso ele seja neutro, precisará formar um complexo com algum elemento carregado que servirá, desta forma, como uma espécie de carreador. Um procedimento bastante comum neste caso é a utilização de surfactantes, como o Dodecil Sulfato de Sódio(SDS) na forma de micelas carregadas. A eletroforese capilar utiliza um capilar oco de sílica fundida entre os eletrodos. Esse capilar possui comprimento normalmente em torno de $40 \mathrm{~cm}$ e um diâmetro interno de 25 a $75 \mu \mathrm{m}$. Aplicando-se voltagens da ordem de até $30 \mathrm{Kv}$, as separações tornaram-se rápidas e eficientes. São comuns análises de 5 minutos ou menos e picos com 50000 a 500000 pratos. Em eletroforese capilar, a amostra é injetada aplicando-se voltagem ou pressão sobre o recipiente contendo a amostra. Por causa do pequeno diâmetro interno do capilar, apenas uma pequeníssima fração da amostra é injetada (ordem de nano-litros)[6].

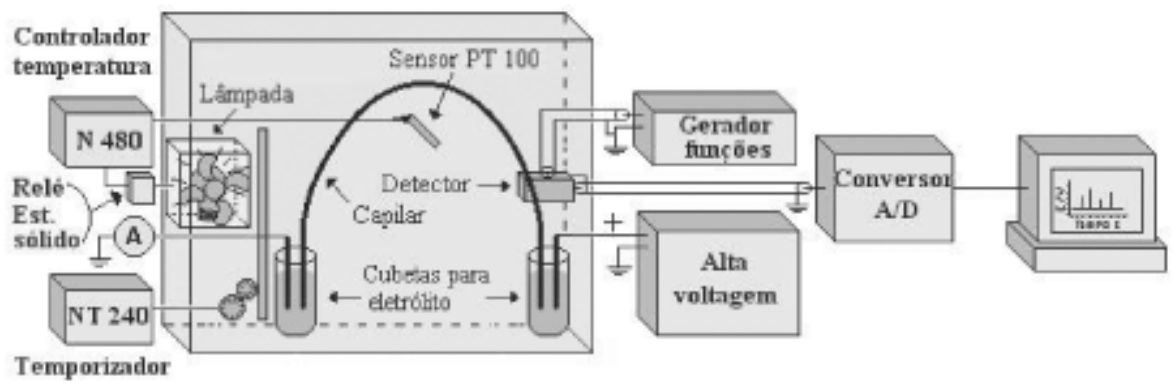

Figura 11 - Representação em diagrama dos blocos do equipamento de eletroforese capilar construído em laboratório [75]. 


\section{CLORIDRATO DE BUPIVACAÍNA SOLUÇÃO INJETÁVEL - FARMACOPEIA BRASILEIRA}

Solução estéril de cloridrato de bupivacaína em água para injetáveis. Contém, no mínimo, $93,0 \%$ e, no máximo, $107,0 \%$ da quantidade declarada de C18H28N2O.HCl.

Metodologia apresentada na Farmacopeia Brasileira, 4 ${ }^{a}$ Edição:

Identificação

a. para um volume de amostra contendo o equivalente a $25 \mathrm{mg}$ de cloridrato de bupivacaína, adicionar água, se necessário, para produzir $10 \mathrm{ml}$ e proceder conforme descrito no teste $A$ de Identificação na monografia Cloridrato de bupivacaína;

b. proceder conforme descrito em substâncias relacionadas. A mancha principal obtida no cromatograma com a solução (1) corresponde em intensidade, cor e posição à mancha obtida no cromatograma com a solução (2);

c. transferir volume de amostra equivalente a $50 \mathrm{mg}$ de cloridrato de bupivacaína para um funil de separação. Alcalinizar com hidróxido de amônio $6 \mathrm{M}$ e extrair com $10 \mathrm{ml}$ de éter etílico. A fase aquosa responde às reações do íoncloreto.

\section{Características}

Determinação de volume. Cumpre o teste.

pH.4,0 a 6,5 .

\subsection{ENSAIOS DE PUREZA}

\subsubsection{Substâncias relacionadas}

Proceder conforme descrito em cromatografia em camada delagada (V.2.17.1) utilizando sílica-Gel GF254, como suporte, e mistura de ciloexanotolueno-dietilamina(75:15:10), como fase móvel. Aplicar, separadamente, à placa 20 $\mu \mathrm{l}$ da amostra e de cada uma das soluções recentemente preparadas, como segue: 
- Solução (1): diluir a amostra em metanol, se necessário, até a concentração de $0,25 \%(p / V)$.

- Solução (2): solução padrão a 0,25\% (p/V) em metanol.

- Solução(3):solução padrão a 0,0025\% (p/V) em metanol.

Desenvolver o cromatograma. Remover a placa, deixar secar ao ar. Nebulizar com solução de iodobismutato de potássio $S R$, preparada como descrito na monografia Cloridrato de Bupivacaína. Qualquer mancha obtida no cromatograma com a solução (1), diferente da mancha principal, não é maior ou mais intensa que a mancha obtida no cromatograma com a solução (3).

2,6-Dimetilanilina. Utilizar volume de amostra contendo o equivalente a $25 \mathrm{mg}$ de cloridrato de bupivacaína anidro, adicionando água, se necessário, para produzir $10 \mathrm{ml}$. Proceder conforme descrito no teste $A$ de Identificação na monografia Cloridrato de bupivacaína, até "Secar o resíduo sob sílica-gel, utilizando pressão reduzida". Dissolver o resíduo em $2 \mathrm{ml}$ de metanol, adicionar $1 \mathrm{ml}$ de solução a $1 \%$ $(\mathrm{p} / \mathrm{V})$ de 4-dimetilaminobenzaldeído em metanol e $2 \mathrm{ml}$ de ácido acético glacial e deixar em repouso à temperatura ambiente por 10 minutos. A cor amarela, eventualmente produzida, não é mais intensa que aquela obtida utilizando, no lugar da amostra, $10 \mathrm{ml}$ de uma solução de 2,6-dimetilanilina a $1 \mu \mathrm{g} / \mathrm{ml}$ em água. No máximo 0,04\% (400 ppm).

\subsubsection{Testes de segurança biológica}

Esterilidade (V.5.1.1). Cumpre o teste.

Endotoxinas bacterianas (V.5.1.9). No máximo 2,5 EU/mg de cloridrato de bupivacaína.

\subsubsection{Doseamento}

Transferir volume de amostra contendo o equivalente a 0,25 g de cloridrato de bupivacaína anidro para funil de separação de $250 \mathrm{ml}$. Alcalinizar com $2 \mathrm{ml}$ de hidróxido de sódio $5 \mathrm{M}$ e extrair com quatro porções de $20 \mathrm{ml}$ de clorofórmio. Reunir os extratos e filtrar sobre sulfato de sódio anidro. Adicionar $10 \mathrm{ml}$ de ácido acético glacial e duas gotas de cristal violeta SI. Titular com ácido perclórico 0,05 M até 
viragem de violeta para verde. Cada $\mathrm{ml}$ de ácido perclórico 0,05 M SV equivale a $16,245 \mathrm{mg}$ de $\mathrm{C}_{18} \mathrm{H}_{28} \mathrm{~N}_{2} \mathrm{O}$. $\mathrm{HCl}$.

\subsection{METODOLOGIAS ALTERNATIVAS PARA DETECÇÃO DO CLORIDRATO DE BUPIVACAÍNA INJETÁVEL}

\subsubsection{Determinação de anestésicos locais e suas impurezas em preparações farmacêuticas usando HPLC com detecção amperométrica}

Um método para a determinação de anestésicos locais e suas impurezas por cromatografia líquida de alta eficiência com detecção amperométrica foi desenvolvido. As análises foram desempenhadas em uma Luna coluna de fase reversa $5 \mu \mathrm{m}$ C-18 (100 mmx4,6 mm). A fase móvel [0.01 mol/l. Tampão a PH 7,9: acetonitrila (45:55)] foi selecionado para a separação e determinação dos anestésicos estudados e suas impurezas. O método desenvolvido neste estudo é sensível e seletivo e pode ser aplicado em estudos de rotina nas formas farmacêuticas de cremes e injetáveis [13].

Existem muitas preparações para anestesia local no mercado farmacêutico, as quais lidocaína, bupivacaína, mepivacaína, prilocaína ou ropivacaína podem ocorrer como substâncias ativas. Elas são substâncias tipo amida e são frequentemente usadas para aliviar dores associadas com procedimentos médicos em cirurgias, ginecologia e na odontologia. As principais impurezas, as quais podem estar presentes nas preparações contendo lidocaína, bupivacaína, mepivacaína, prilocaína ou ropivacaína são 2,6-dimetilanilina(2,6-DMA) e o-toluidine (o-TLD). Estas impurezas podem ser formadas durante a síntese destes anestésicos locais ou durante a estocagem das preparações[13].

2,6- Dimetilanilina e o-toluidina podem ser potenciais impurezas tecnológicas porque elas são usadas como substratos na síntese de produtos farmacêuticos. Além disso, elas podem também aparecer como produtos de decomposição durante a estocagem dos medicamentos. 2,6-Dimetilanilina também demonstrou atividade anestésica, mas é significantemente mais tóxico que o composto de origem. De todos os anestésicos amídicos usados na prática anestésica, prilocaína é o menos tóxico [13]. 
O nível permitido de 2,6-DMA e de o-TLD em substâncias é 100 ppm(Farmacopeia europeia 4). A farmacopeia britânica (2003) permite para a lidocaína e bupivacaína na forma de géis e injeções não mais que 400 ppm de 2,6DMA. Métodos analíticos farmacopeicos para a determinação de impurezas de 2,6DMA e o-TLD não são suficientemente sensíveis e precisos, assim, frequentemente fornecem resultados ambíguos. Isto motivou o desenvolvimento de uma nova metodologia analítica, sensível e específica cromatografia líquida de alta eficiência com dececção amperométrica(HPLC-ED) para a quantificação de 2,6-DMA,o-tld e anestésicos locais em várias preparações farmacêuticas [13].

As técnicas mais frequentemente recomendadas na literatura para a determinação destes compostos são Cromatografia Líquida de Alta Eficiência e Cromatografia Gasosa (GC) acopladas com vários métodos de detecção como:Ultra violeta(UV), espectrometria de massa, eletroquímicos ou possivelmente com a aplicação de um detector de captura de elétrons.Para isolamento e determinação de toluidina e seus derivados eletroforese capilar também tem sido usada.

\subsubsection{Substância analisada}

Com relação à bupivacaína, este estudo analisou amostra do fármaco Marcaine Spinal $(0,5 \%)$ do laboratório Astrazeneca,e padrão de trabalho Cloridrato de Bupivacaína monohidratada, também do laboratório Astrazeneca. Os resultados servirão como parâmetro para a comparação com os medicamentos que serão analisados durante o período de mestrado, onde o laboratório farmacêutico forneceu o medicamento com o mesmo princípio ativo comercializado no Brasil.

\subsubsection{Reagentes}

- Ácido clorídrico para ajuste da solução tampão.,

- Tris (tris-(hydroxymethyl)-aminometano) de AppliChem,

- Acetonitrila

- Água Miliq 


\subsubsection{Fase móvel}

Tris Buffer-0,01 mol/l Solução Tris ajustada para o $\mathrm{PH} 7,9 \mathrm{com}$ ácido clorídrico:acetonitrila (45:55).

\subsubsection{Solução padrão}

As soluções padrões da Bupivacaína foram diariamente preparadas por dissolução de $10 \mathrm{mg}$ do padrão de trabalho na fase móvel em um frasco volumétrico de $10 \mathrm{ml}$. Assim as soluções preparadas foram diluídas com fase móvel para a concentração de $10 \mu \mathrm{g} / \mathrm{ml}$.

Soluções padrões de 2,6-DMA e $o$-TLD foram diariamente preparadas em um frasco volumétrico de $10 \mathrm{ml}$ por dissolução de $10 \mathrm{mg}$ de 2,6-DMA ou o-TLD na fase móvel. A partir destas soluções, sucessivas diluições foram então preparadas em concentrações de 5 a $20 \mu \mathrm{g} / \mathrm{ml}$ para 2,6-DMA ou de 5 a $20 \mu \mathrm{g} / \mathrm{ml}$ para $o-T L D$.

Todas as soluções foram estocadas no escuro quando não estavam em uso.

\subsubsection{Equipamentos}

OS equipamentos foram utilizados no laboratório de química farmacêutica da central analítica da FCF da Universidade de São Paulo.

- Sistema de cromatografia líquida de alta eficiência (CLAE) Simadzu, software Class VP, detector SPD-10 AUv-Vis e Detector RID-10 A.

- Coluna C-18 $150 \mathrm{~mm}$ x 4,60 mm, marca Gemini, partícula de 5 microns.

- Sistema de Eletroforese Capilar(EC) BeckamnCoulter, software 32 Karat 8.0.

- Capilar de sílica fundida $32 \mathrm{~cm}$ x 75 um de diâmetro interno.

\subsection{PREPARAÇÕES DE AMOSTRAS E DETERMINAÇÃO DE BUPIVACAÍNA NAS FORMULAÇÕES FARMACÊUTICAS}

Para os estudos das preparações na forma de injetáveis, amostras correspondentes a $10 \mathrm{mg}$ de substâncias ativa foram medidas em frascos 
volumétricos de $10 \mathrm{ml}$ e completou-se o volume com a fase móvel. Assim soluções preparadas foram diluídas para a concentração de $10 \mu \mathrm{g} / \mathrm{ml}$. Então, porções de $20 \mu \mathrm{l}$ das soluções preparadas foram introduzidas na coluna e os cromatogramas foram registrados por 500 segundos usando um detector amperométrico no potencial de $+1,0 \mathrm{~V}$ do eletrodo de carbono vítreo versus eletrodo de referência $\mathrm{Ag} / \mathrm{AgCl}$. A intensidade da corrente foi medida pelos tempos de retenção a cerca de 100,111,124,156,230,263 e 415 s para o-TLD, Mepivacaína. Prilocaína, 2,6-DMA, Lidocaína, Ropivacaína e Bupivacaína, respectivamente. No presente estudo, delimitou-se o objetivo de caracterização apenas para o anestésico cloridrato de bupivacaína e seus possíveis produtos de degradação. 


\section{JUSTIFICATIVA}

Tudo o que está sendo discutido neste projeto de pesquisa está inserido no perfil profissional e acadêmico do pós graduando. O mesmo formou-se em Ciências Farmacêuticas e Química(Bacharelado) pela Universidade de Brasília(UnB).

No ramo profissional, o controle da qualidade de medicamentos é área de atuação direta da Agência Nacional de Vigilância Sanitária, instituição vinculada ao Ministério da Saúde, da qual o pós-graduando faz parte desde 2005.

Neste contexto, destaca-se a atuação da Gerência Geral de Fiscalização de Insumos, Medicamentos e Produtos(GGIMP).

Realizou-se um levantamento das notificações de desvios de qualidade através das Queixas Técnicas (QT) e eventos adversos através do sistema de notificações da Anvisa obtendo-se os seguintes resultados:

No período entre 10/04/2007 a 10/04/2012 foram registradas aproximadamente 510 notificações de desvios de qualidade sobre cloridrato de bupivacaína [7]. 


\section{MATERIAL, MÉTODOS E REAGENTES}

Consulta de ampla gama de referências bibliográficas, a nível nacional e internacional, para as atividades teórico-práticas da pós-graduação.

Nas atividades laboratoriais, serão utilizados os chamados métodos clássicos de análise se substâncias, como os métodos volumétricos e gravimétricos, além de métodos instrumentais de identificação, separação e quantificação das substâncias.

Destacando-se o método de Cromatografia Líquida de Alta Eficiênciae Eletroforese Capilar.

Como reagentes utiliza-se fase móvel para cromatografia líquida de alta eficiência composta por Acetonitrila: tampão tris buffer 45:55 ajustado com ácido clorídrico a pH 7,9.

Para eletroforese capilar utiliza-se solução aquosa de tretanolamina a $70 \mathrm{mM}$ ajustada a pH 3,0 com ácido fosfórico. 


\section{FORMA DE ANÁLISE DOS RESULTADOS - PARTE EXPERIMENTAL}

A análise dos resultados experimentais está sendo feita de acordo com os padrões esperados estabelecidos nas principais farmacopeias.

Os resultados serão considerados como pertinentes ou não pertinentes, sendo aceitos ou rejeitados de acordo com os padrões pré-estabelecidos. Serão utilizadas técnicas de amostragem de lotes dos medicamentos, e análises de alíquotas dos mesmos.

- Contato com laboratório farmacêutico em 24/09/2012 para fornecimento de amostras do fármaco "Cloridrato de Bupivacaína".

- As amostras do medicamento foram recebidas na Faculdade de Ciências Farmacêuticas(FCF) e encaminhadas ao laboratório de controle físicoquímico da qualidade e estão sob os cuidados da professora Érika Rosa Maria Kedor-Hackmann.

- Contato com alguns laboratórios químicos para aquisição de padrões analíticos das impurezas o-toluidina e 2,6-Dimetilanilina.

- Houve já o pronunciamento dos laboratórios e houve aquisição dos padrões para referência nas análises.

\subsection{ATIVIDADES DE PESQUISA EM LABORATÓRIO}

\subsubsection{Identificação}

Dando prosseguimento as atividades de pós-graduação, iniciou-se as atividades de pesquisa em laboratório através de alguns testes de identificação recomendados pelas Farmacopeias Britânica, Americana e Brasileira.

O primeiro teste de identificação recomendado pela Farmacopeia Britânica [14] foi o teste de ponto de fusão.

Os ensaios de identificação podem ser classificados em físico ou químicos, ou ainda como métodos instrumentais ou clássicos.

Independente do método utilizado um ensaio de identificação deve ser específico e confiável, de baixo custo e de fácil realização. 
Considerando que o fármaco é o princípio ativo do medicamento, sua identificação é um quesito básico para eficácia e segurança do produto. Outrossim, há ainda o risco de adulteração de matérias-primas excipientes por outras de menor custo que, embora de características semelhantes, poderão acarretar em problemas potencias de formulação [6].

\section{A) Ponto de Fusão}

Uma das características de uma substância pura é apresentar um ponto de fusão ou faixa de temperatura de fusão definida. Se não for pura, a substância exibirá mudança no ponto de fusão. Esse fenômeno é comumente usado para determinar a pureza do fármaco e, em alguns casos, a compatibilidade de várias substâncias antes da inclusão na mesma forma farmacêutica [8].

O comportamento de uma substância sólida impura é bem diferente. A substância geralmente inicia sua fusão a uma temperatura abaixo do ponto de fusão da substância pura [6].

Segundo dados obtidos na Farmacopeia Britânica [14], o ponto de fusão da substância Cloridrato de Bupivacaína seria em $254^{\circ} \mathrm{C}$.

Em 13/06/2013, realizou-se o teste de ponto de fusão no Laboratório de Controle físico químico de qualidade de medicamentos da Faculdade de ciências farmacêuticas da Universidade de São Paulo.

O resultado obtido em duas alíquotas da amostra do padrão de cloridrato de bupivacaína enviado pelo laboratório farmacêutico Cristália foi o mesmo. Observouse o início da liquefação dos cristais da substância a $249^{\circ} \mathrm{C}$ e completa fusão dos mesmos a $254^{\circ} \mathrm{C}$.

Os resultados evidenciam a pureza da amostra da substância analisada.

B) Espectroscopia no UV-Vis

O UV-Visível talvez seja uma das técnicas mais utilizadas em todo o mundo, em especial em análises quantitativas em laboratórios químicos, clínicos e farmacêuticos.

A relação fotomeria-luz deve ser encarada em termos de energia e não em termos de luz e cor. A energia, por sua vez, apresenta relação inversa com 0 comprimento de onda, simbolizando por $\lambda$. A unidade para medida do comprimento de onda $\lambda$ é o nanômetro $(\mathrm{nm})[6]$. 
A região do ultravioleta do espectro eletromagnético estende-se da extremidade de baixo comprimento de onda da região do visível $\left(4 \times 10^{-7} \mathrm{~m}\right)$ até $10^{-8}$ $\mathrm{m}$, mas a estreita faixa de $2 \times 10^{-7} \mathrm{~m}$ até $4 \times 10^{-7} \mathrm{~m}$ é a região de maior interesse para os químicos orgânicos, sendo o $\mathrm{nm}=10^{-9} \mathrm{~m}$, a faixa de interesse no ultravioleta é de 200 a $400 \mathrm{~nm}[15]$.

Um espectrômetro de UV-Vis mede a quantidade de luz absorvida em cada comprimento de onda das regiões do UV e do Visível do espectro eletromagnético. Se o composto absorve luz em um comprimento de onda particular, a intensidade do feixe $\left(I_{s}\right)$ será menor do que aquela do feixe de referência $\left(I_{r}\right)$. $O$ instrumento indica isso produzindo um gráfico do comprimento de onda de toda a região versus a absorvância (A) de luz em cada comprimento de onda. Tal gráfico é chamado de espectro de absorção [16].

\section{- Procedimento Experimental}

Seguindo procedimento descrito na Farmacopéia Americana, 34 edição [74],desempenhou-se ensaio analítico para identificação de cloridrato de bupivacaína por espectroscopia no UV-Visível utilizando-se o espectrofotômetro de UV-Vis do laboratório de controle físico-químico de qualidade de medicamentos da FCF/USP.

Primeiramente, seguindo o procedimento descrito na farmacopeia, preparou-

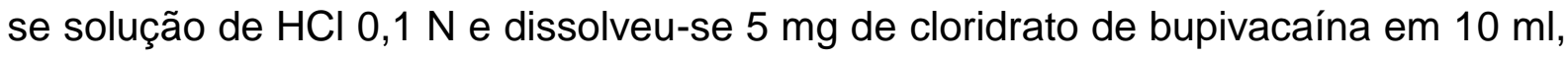
obtendo-se concentração de $500 \mu \mathrm{g} / \mathrm{ml}$.

Efetuou-se a análise do branco, e posteriormente com a amostra dissolvida, o resultado não foi coerente.

Cogitou-se a hipótese de amostra não dissolvida. Decidiu-se preparar novo ensaio no dia seguinte.

Retornou-se ao laboratório de controle físico-químico da FCF/USP para novo ensaio de UV-Vis, de forma a obter melhor dissolução da amostra do fármaco em questão, utilizou-se o recurso do banho em ultrassom durante 5 minutos. Após, realizou-se novo procedimento de leitura em UV-Vis, o comprimento de onda para o pico de absorvância ocorreu em $\lambda=215 \mathrm{~nm}$.

O resultado obtido não foi muito coerente com o descrito na Farmacopeia Americana, que citava o $\lambda=271 \mathrm{~nm}$. 
Para obtenção de melhor resultado, repetiu-se o teste na central analítica da FCF/USP, procedendo-se com alguns ajustes no intervalo do comprimento de onda e Absorbância, o resultado obtido é apresentado a seguir:

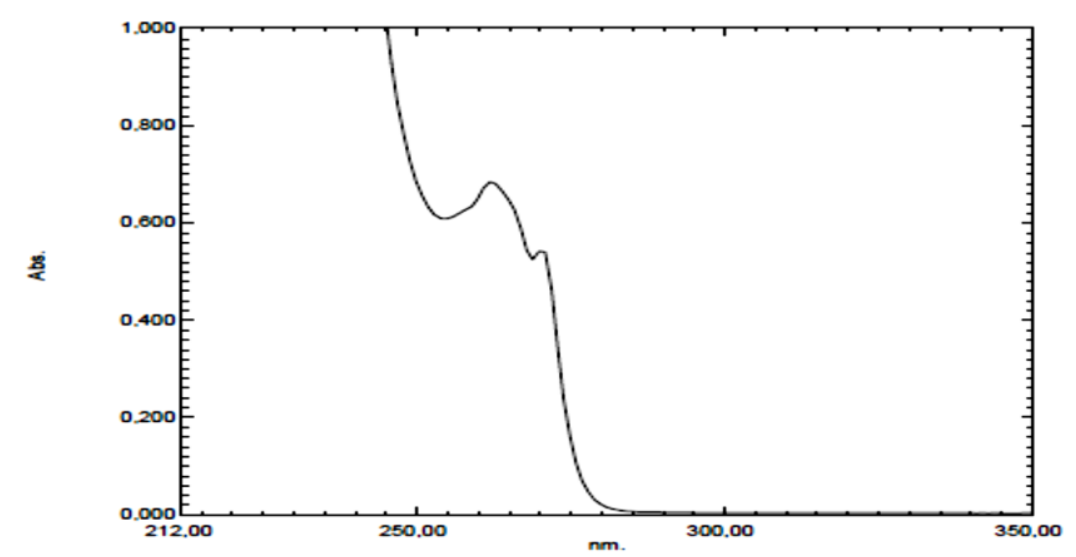

Figura 12 - Observa-se o pico característico para Cloridrato de Bupivacaína a $271 \mathrm{~nm}$ de comprimento de onda conforme descrito na farmacopeia americana 34를 edição.espectro de absorção da solução de cloridrato de bupivacaína (0,05\%) em ácido clorídrico 0,1 M no UV-Vis.

Tabela 2 - UV-VIS

\begin{tabular}{ccc}
\hline № & Wavelength & Absorbance \\
1 & 262,00 & 0,683 \\
2 & 217,00 & 0,539 \\
3 & & \\
\hline
\end{tabular}

C) Espectroscopia no Infravermelho

A espectrometria no infravermelho (IV) fornece uma técnica experimental rápida que pode dar evidências para a presença de vários grupos funcionais. $\mathrm{Na}$ presença de uma amostra de identidade desconhecida, por exemplo, dentre as primeiras que se deve fazer, seria obter um espectro de infravermelho [16].

O objetivo da espectroscopia de absorção no IV é a determinação dos grupos funcionais de um dado material. Cada grupo absorve em frequência característica de radiação na região do IV. Assim, um gráfico de intensidade de radiação versus freqüência, o espectrograma de IV, permite caracterizar os grupos funcionais de um padrão ou de um material desconhecido [19].

A reflexão no infravermelho vem sendo utilizada na análise de medicamentos desde o início dos anos 1970, porém sua expansão veio a ocorrer nos anos 1990 
[41], principalmente com a evolução da informatização dos equipamentos e da associação destes com as ferramentas de análise multivariada.

Um dos focos dos trabalhos realizados vem sendo a aplicação da espectroscopia no infravermelho próximo para o controle de medicamentos nas diversas fases de produção ([33]; [34]; [35]; [36]; [37]; [38]; [39];[40]). Porém a maior parte da literatura disponível trata de aplicações da espectroscopia por reflexão difusa no infravermelho próximo na quantificação de ingredientes ativos, sendo a maior parte dos trabalhos aplicada ao produto final ([42]; [43]; [44]; [45]; [46]; [47]; [48]; [40]).

Espectroscopia de infravermelho próximo é uma rápida e não destrutiva técnica que oferece muitas vantagens para uma ampla série de aplicações na indústria farmacêutica. É uma técnica muito rápida: utiliza os mais modernos instrumentos(Transformada de Fourier (FT)-NIR), um espectro pode ser gerado em alguns segundos. A mais interessante vantagem da técnica é o caráter não destrutivo das análises, neste sentido, evita muitos passos na preparação das amostras,minimizando fontes de erros. Isto possibilita também, a reutilização da mesma amostra depois da primeira medição [49].

Recentes avanços em instrumentação analítica e análise de técnicas para processos complexos têm fomentado novos usos para espectoscopia de infravermelho próximo em vários campos na indústria para análises qualitativa e quantitativa em preparações farmacêuticas [50].

- Procedimento experimental

Realizou-se um levantamento através de um banco de dados específico dentro do sistema integrado de bibliotecas da USP, um espectro referência padrão para o cloridrato de Bupivacaína.O espectro padrão está demonstrado abaixo: 


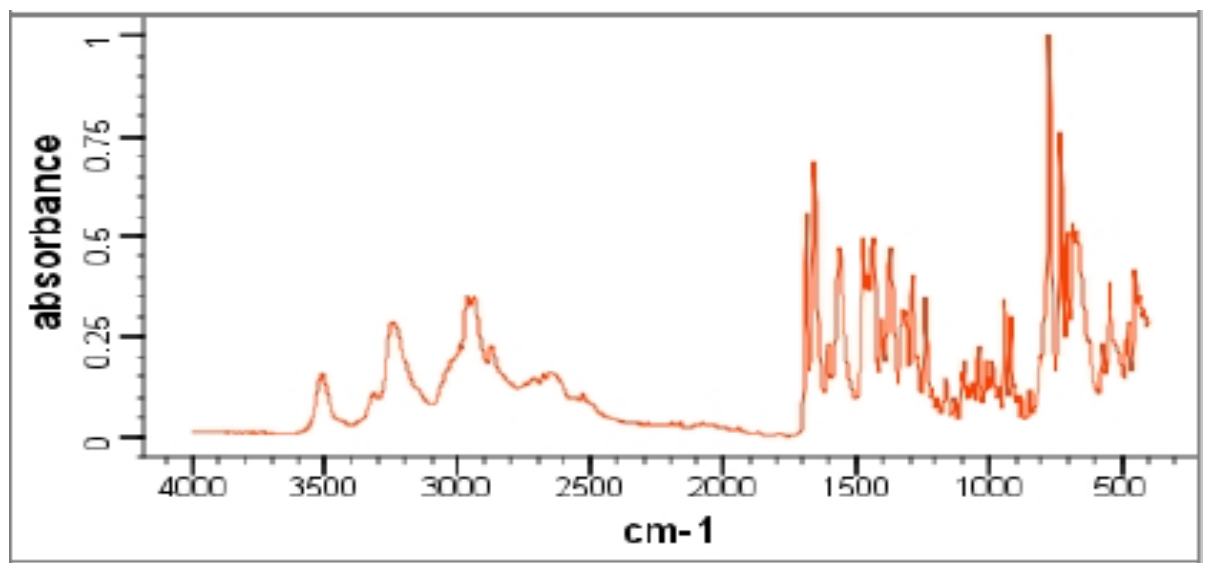

Figura 13 - Espectro de Absorbância Padrão em IV para o cloridrato de Bupivacaína [20]

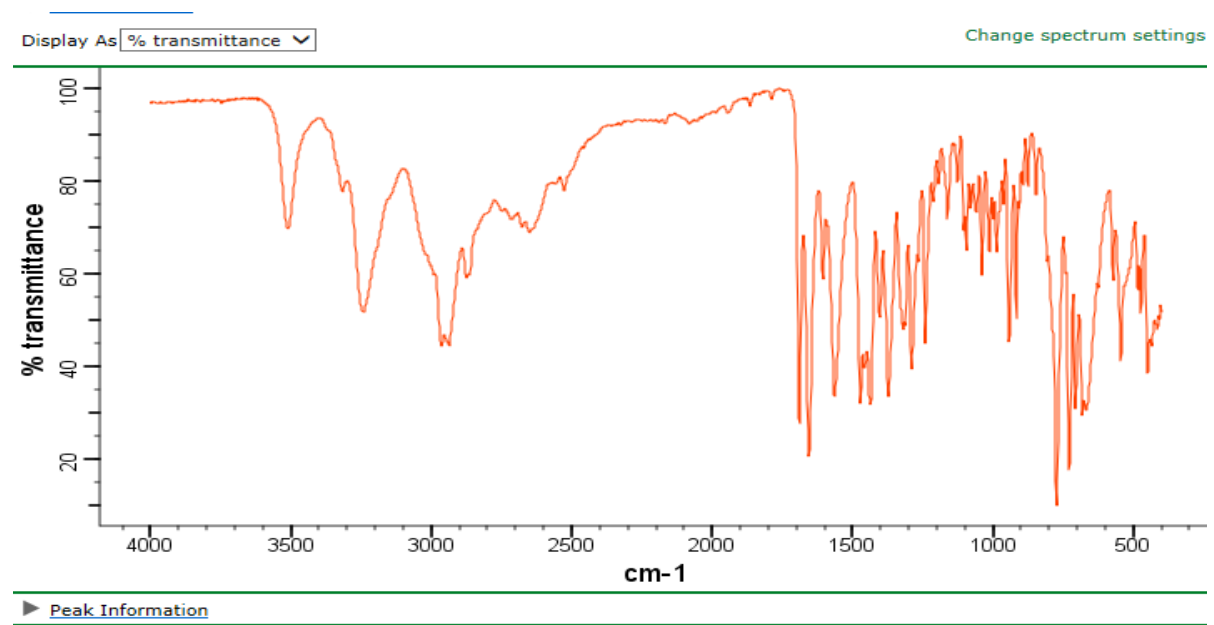

Figura 14- Espectro de transmitância padrão em IV para o cloridrato de bupivacaína A mesma substância gera um espectro de IV para o parâmetro Transmitância[20]

A amostra foi encaminhada para a central analítica do Instituto de Química (IQ) da USP para análise no espectrômetro de Infravermelho para posterior comparação. Obteve-se então o seguinte espectro para a referida substância: 


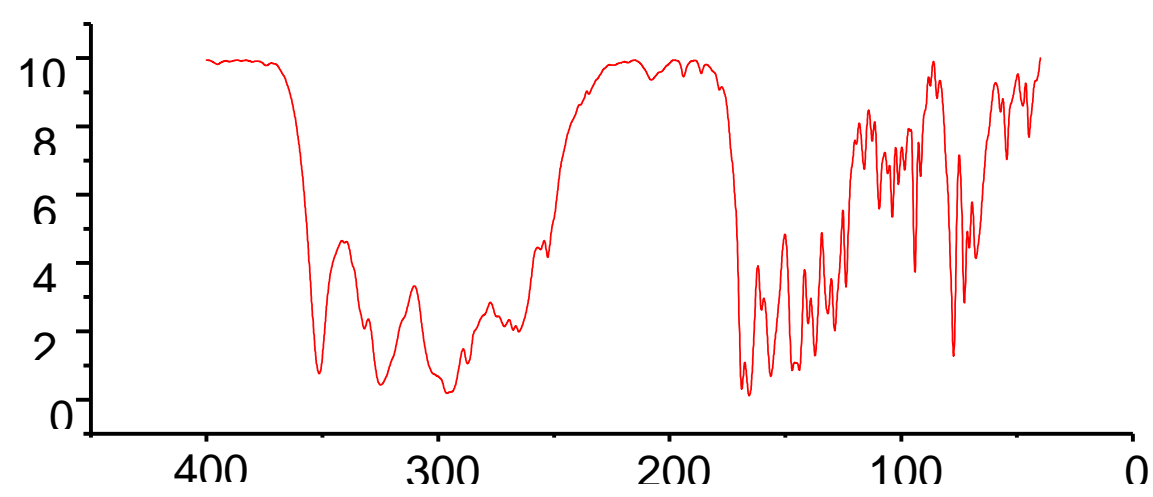

Figura 15 - Espectro de IV para a matéria prima obtido no laboratório do Instituto de Química da Universidade de São Paulo.

Analisando-se os espectros comparativamente, observa-se grande similaridade entre os dois, evidenciando-se a autenticidade da amostra recebida do laboratório farmacêutico.

\subsection{ANÁLISE TÉRMICA}

\subsubsection{Métodos térmicos}

Uma definição geralmente aceita para análise térmica é "Um grupo de técnicas nas quais uma propriedade física de uma substância e/ou de seus produtos de reação é medida em função da temperatura, enquanto a substância é submetida a uma variação de temperatura controlada e programada". Os métodos térmicos encontram ampla aplicação tanto em controle de qualidade como em pesquisa de produtos industriais, como polímeros, produtos farmacêuticos, argilas e minerais, metais e ligas. Esses métodos incluem termogravimetria(TG),Análise Térmica Diferencial (DTA) e Calorimetria Exploratória Diferencial(DSC)[22].

Para a análise da matéria prima de cloridrato de bupivacaína, utilizou-se os métodos DTA e DSC, que serão descritas detalhadamente a seguir.

\subsubsection{Análise térmica diferencial}

Na Análise Térmica Diferencial (DTA), ao invés de se avaliar a variação de massa, avalia-se a variação da temperatura de uma amostra perante a um padrão de referência inerte. Nesse experimento, tanto a amostra quanto o padrão são 
submetidos a um programa controlado de temperatura, sob condições idênticas de atmosfera [6].

O padrão utilizado é um material inerte, por exemplo, o estanho ou índio metálico. As variações de temperatura correspondem a processos exotérmicos (reações de decomposição) ou endotérmicos (transições de estados físicos).

As curvas DTA e TGA apresentam os registros de $\Delta T$ em função da temperatura (T) ou do tempo (t). Os picos endotérmicos são descendentes, enquanto os picos exotérmicos ascendentes.
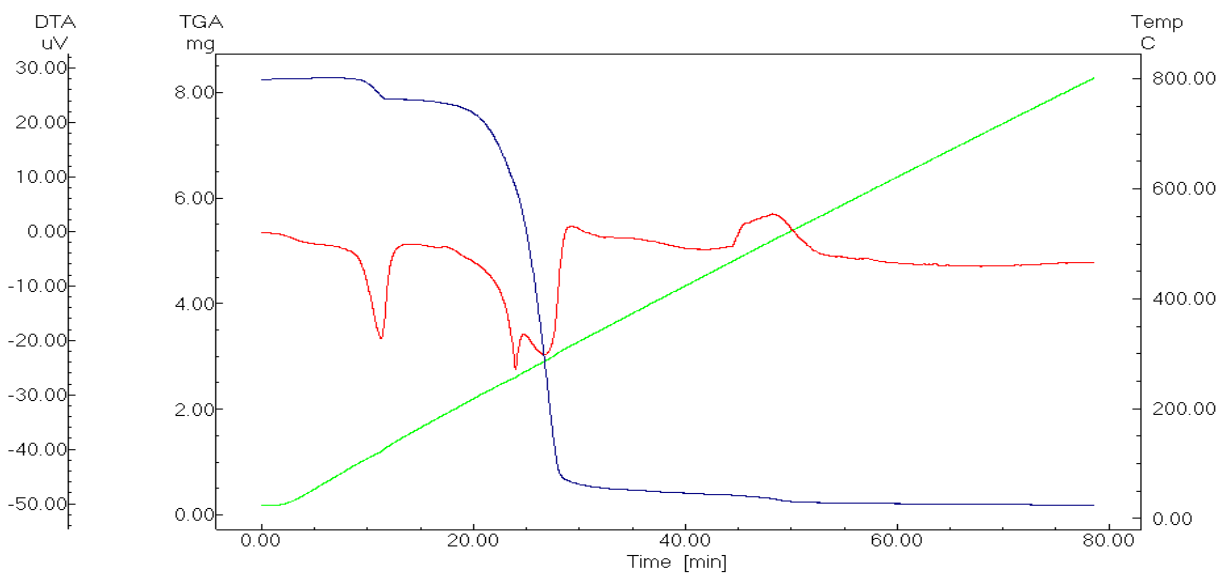

Figura 16 - Curva DTA/TGA obtida para o cloridrato de bupivacaína matéria prima.

\subsubsection{Calorimetria exploratória diferencial}

$\mathrm{Na}$ calorimetria exploratória diferencial se mede ao invés da diferença de temperatura a diferença de energia que é fornecida à substância em análise em comparação a um padrão inerte.

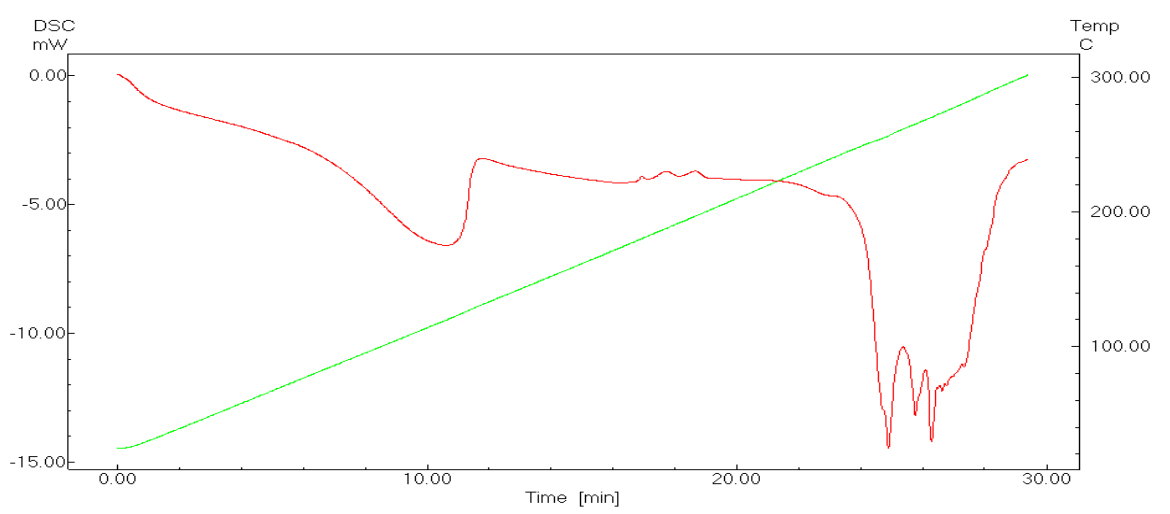

Figura 17 - Curva DSC obtida para o cloridrato de bupivacaína matéria prima. 


\subsubsection{Cromatografia em camada delgada}

A cromatografia em Camada Delgada (CCD) consiste na separação dos componentes de uma mistura através da migração diferencial sobre uma camada delgada de adsovente retido sobre uma superfície plana. $O$ processo de separação está fundamentado, principalmente, no fenômeno da adsorção. Entretanto, usandose fases estacionárias tratadas, pode ocorrer também por partição ou troca iônica, o que permite seu emprego tanto na separação de substâncias hidrofóbicas como hidrofílicas [30].

O solvente começa a avançar em sentido ascendente, provocando uma migração diferenciada dos componentes da amostra. $O$ resultado é uma série de manchas distribuídas verticalmente na placa (Figura 18)[25].

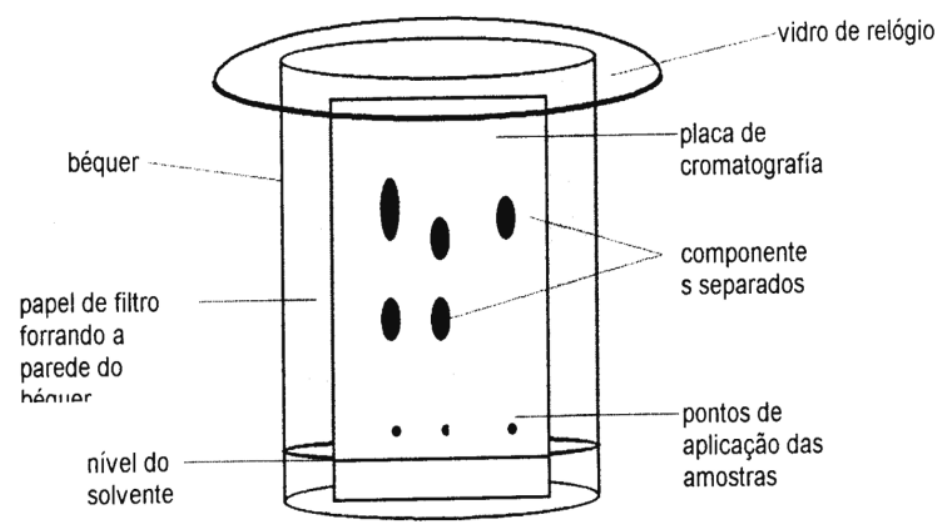

Figura 18 - Cromatograma em desenvolvimento

Sob condições preestabelecidas (adsorvente, solvente de desenvolvimento, espessura da camada e homogeneidade), a razão entre a velocidade do movimento de um componente dom relação à velocidade do movimento da frente do solvente, ou $\mathrm{R}_{\mathrm{f}}$, é uma propriedade de cada composto [25]

$\mathrm{O}$ valor de $\mathrm{R}_{\mathrm{f}}$ é determinado medindo-se a distância percorrida por uma substância a partir do ponto de aplicação até o centro da mancha dividido pela distância percorrida pelo solvente, a partir do mesmo ponto de aplicação (Figura 19). 


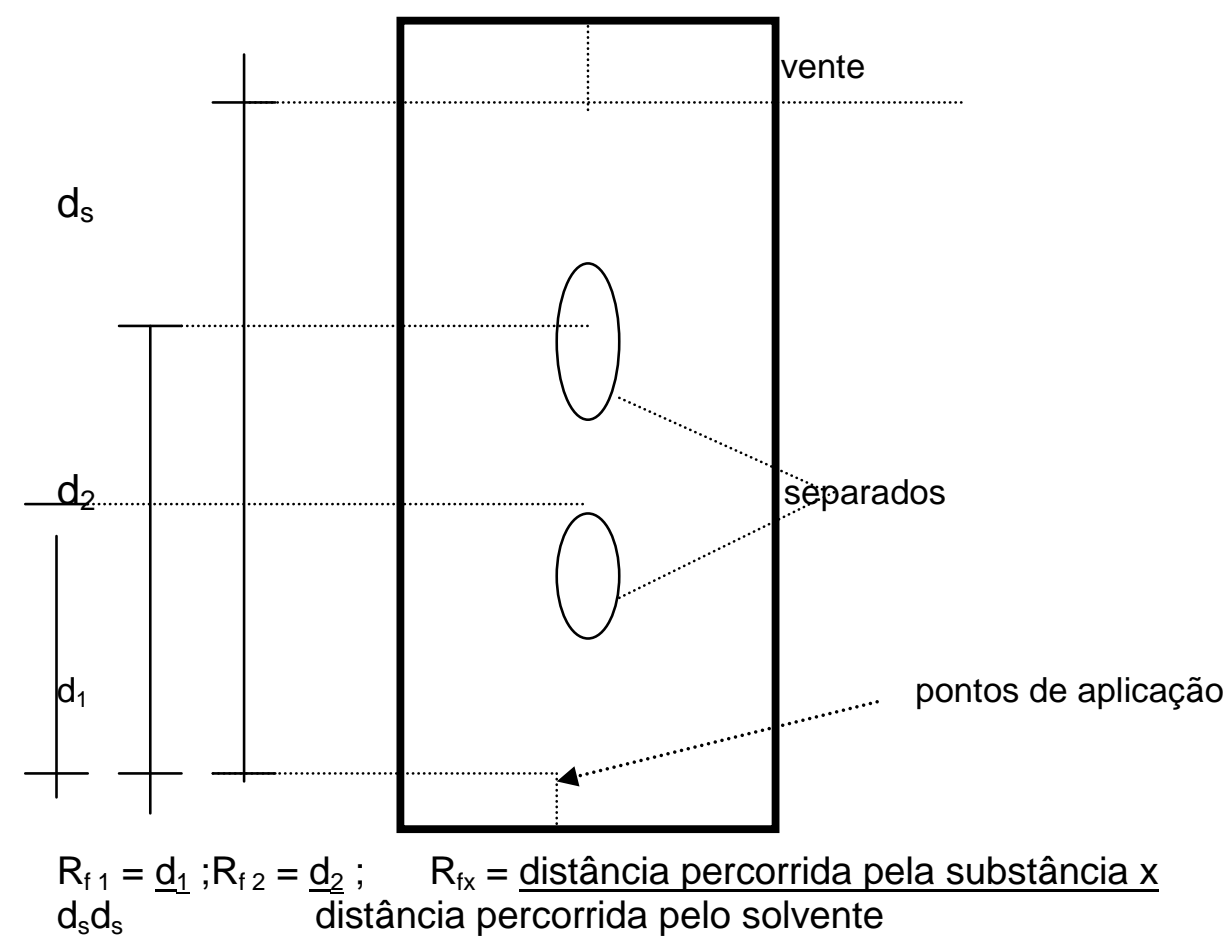

Figura 19 - Determinação do valor de Rf

Desenvolveu-se um teste em Cromatografia de Camada Delgada onde foi utilizada uma placa de sílica gel seguindo o procedimento descrito na farmacopeia brasileira 4⿳亠丷厂 edição [26]:

Preparou-se duas soluções a 5 e $0,05 \%(\mathrm{p} / \mathrm{v})$ em metanol de cloridrato de bupivacaína,fase móvel de cilohexano:tolueno: dietilamina (75:15:10), utilizou-se iodo bismutato de potássio como revelador. A distância percorrida pelo solvente foi de 10,8 cm e a distância percorrida pelas amostras nas duas concentrações foi 9,8 cm. $O$ resultado mostrou-se coerente com o descrito na farmacopeia mostrando o mesmo valor de $R_{f}$ para a substância nas duas concentrações, variando apenas a intensidade da marca observada na placa cromatográfica. 
Figura 20 - Placa de Cromatografia em Camada Delagada (CCD)

Nota: Observa-se a mesma distância percorrida pelo principio ativo a partir do ponto de aplicação, variando apenas a intensidade da coloração da marca pela diferença de concentração entre as duas amostras

Conforme teoria descrita anteriormente, calculou-se o chamado Rf para a substância em questão:

$$
\mathrm{Rf}=\underline{9,8 \mathrm{~cm}}=0,90
$$

$10,8 \mathrm{~cm}$

\subsubsection{Análise em cromatografia líquida de alta eficiência}

Conforme descrição feita anteriormente, os procedimentos foram realizados utilizando-se um cromatógrafo líquido de alta eficiência para a caracterização qualitativa e quantitativa do princípio ativo e dos padrões de impurezas.Analisou-se primeiramente o princípio ativo do medicamento, o mesmo fornecido pelo laboratório fabricante.

As análises feitas durante 0 período da pós-graduação mostraram-se bastante coerentes com o obtido previamente na literatura. Analisou-se em concentrações que variaram entre 50 e $300 \mu \mathrm{g} / \mathrm{mL}$ conforme os cromatogramas demonstrados a seguir: 


\section{Fase móvel Branco}

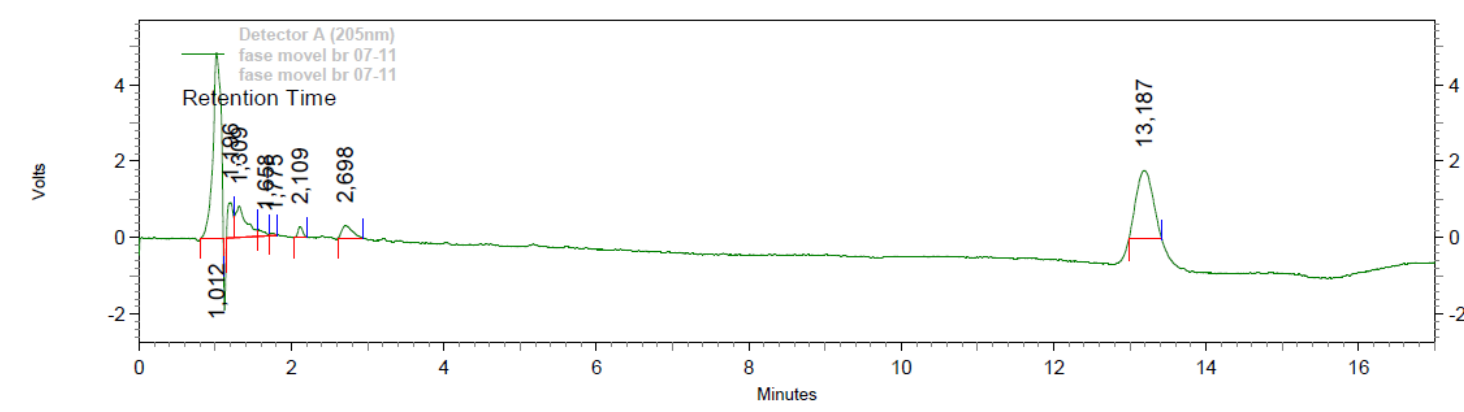

Figura 21 - Cromatograma da solução de da fase móvel; Condições: Coluna Gemini $\mathrm{C}_{18}(5$ $\mu \mathrm{m}, 150 \times 4,6 \mathrm{~mm}$ ), vazão: 1,5 mL $\mathrm{min}^{-1}$, fase móvel: ACN : Tris Buffer 45:55, pH 7,9 ajustado com ácido clorídrico 1M; detecção UV de 205 nm.

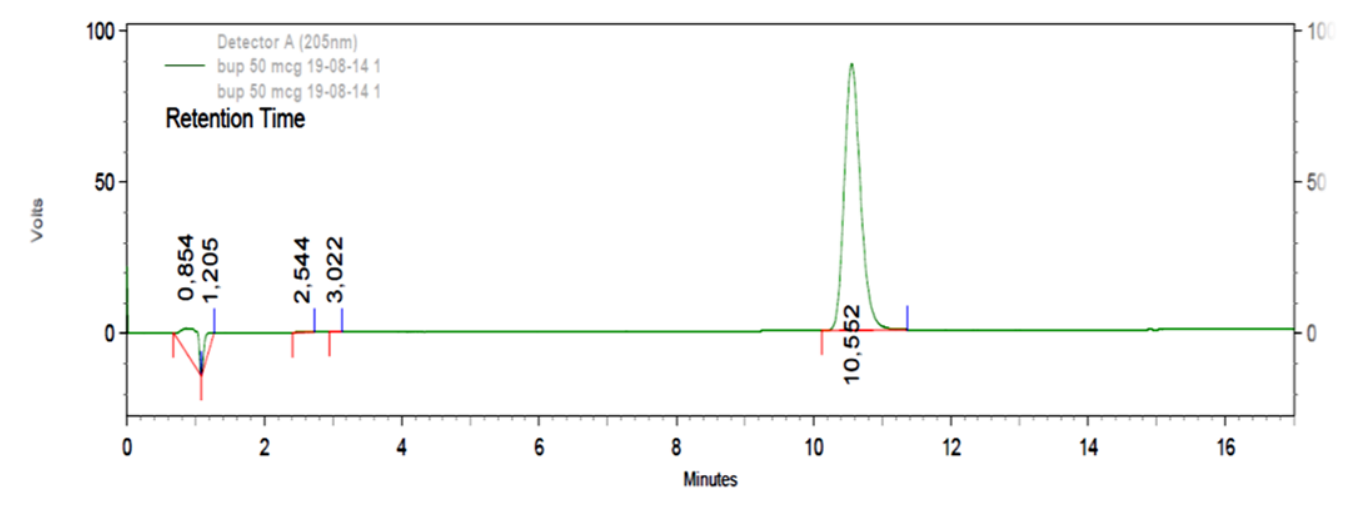

Figura 22 - Cromatograma da solução de cloridrato de bupivacaína $50 \mu \mathrm{g} \mathrm{mL}^{-1}$; Condições: Coluna Gemini $C_{18}(5 \mu \mathrm{m}, 150 \times 4,6 \mathrm{~mm})$, vazão: $1,5 \mathrm{~mL} \mathrm{~min}^{-1}$, fase móvel: ACN : Tris Buffer 45:55, pH 7,9 ajustado com ácido clorídrico 1M; detecção UV de $205 \mathrm{~nm}$.

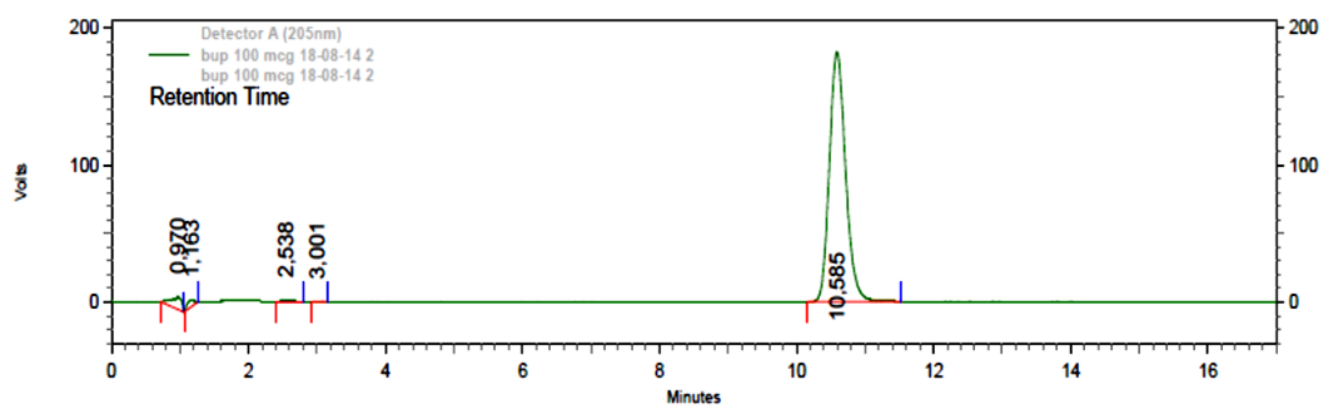

Figura 23 - Cromatograma da solução de cloridrato de bupivacaína $100 \mu \mathrm{g} \mathrm{mL}^{-1}$; Condições: Coluna Gemini $C_{18}(5 \mu \mathrm{m}, 150 \times 4,6 \mathrm{~mm})$, vazão: $1,5 \mathrm{~mL} \mathrm{~min}^{-1}$, fase móvel: ACN : Tris Buffer 45:55, pH 7,9 ajustado com ácido clorídrico 1M; detecção UV de 205 nm. 


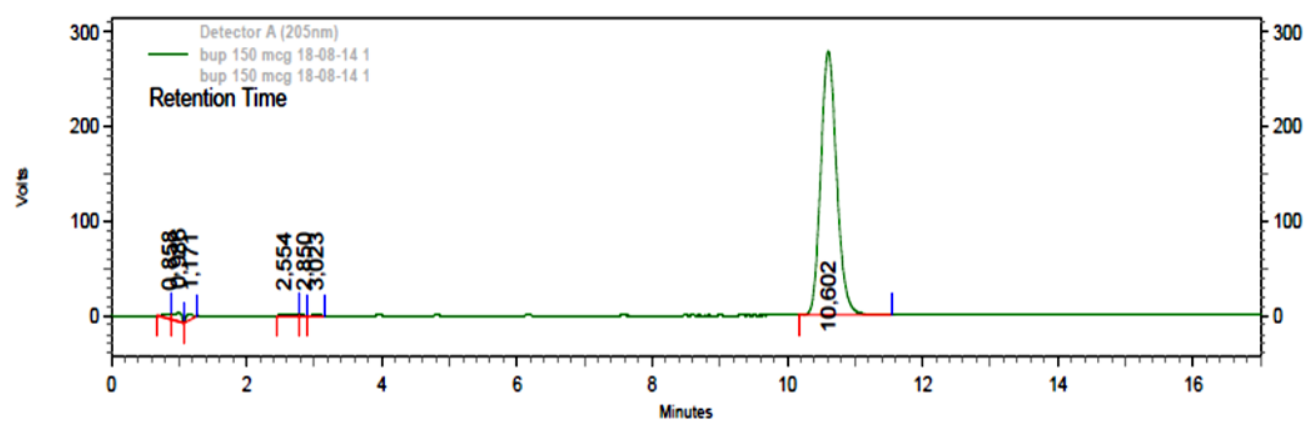

Figura 24 - Cromatograma da solução de cloridrato de bupivacaína $150 \mu \mathrm{g} \mathrm{mL}^{-1}$; Condições: Coluna Gemini $\mathrm{C}_{18}(5 \mu \mathrm{m}, 150 \times 4,6 \mathrm{~mm})$, vazão: $1,5 \mathrm{~mL} \mathrm{~min}^{-1}$, fase móvel: ACN : Tris Buffer 45:55, pH 7,9 ajustado com ácido clorídrico 1M; detecção UV de 205 nm.

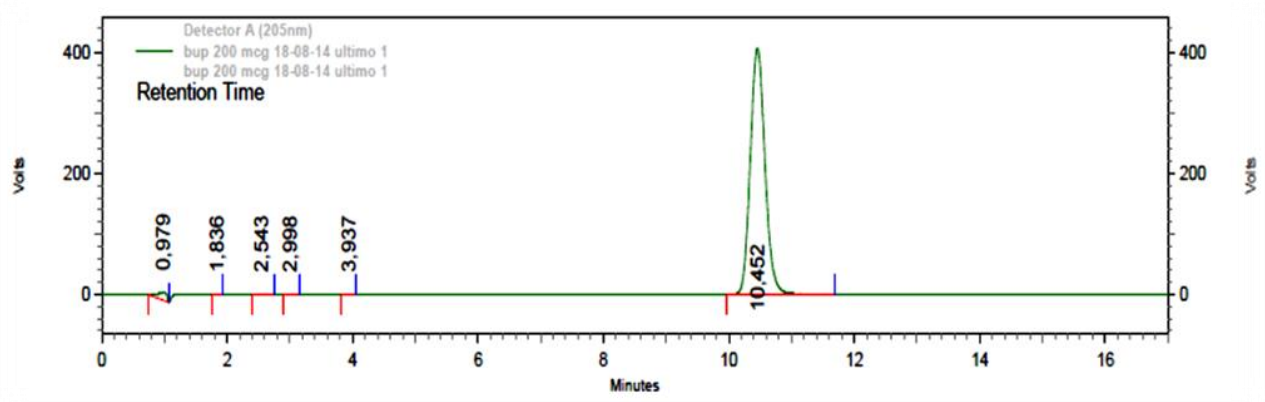

Figura 25 - Cromatograma da solução de cloridrato de bupivacaína $200 \mu \mathrm{g} \mathrm{mL}^{-1}$; Condições: Coluna Gemini $C_{18}(5 \mu \mathrm{m}, 150 \times 4,6 \mathrm{~mm})$, vazão: $1,5 \mathrm{~mL} \mathrm{~min}^{-1}$, fase móvel: ACN : Tris Buffer 45:55, pH 7,9 ajustado com ácido clorídrico 1M; detecção UV de $205 \mathrm{~nm}$.

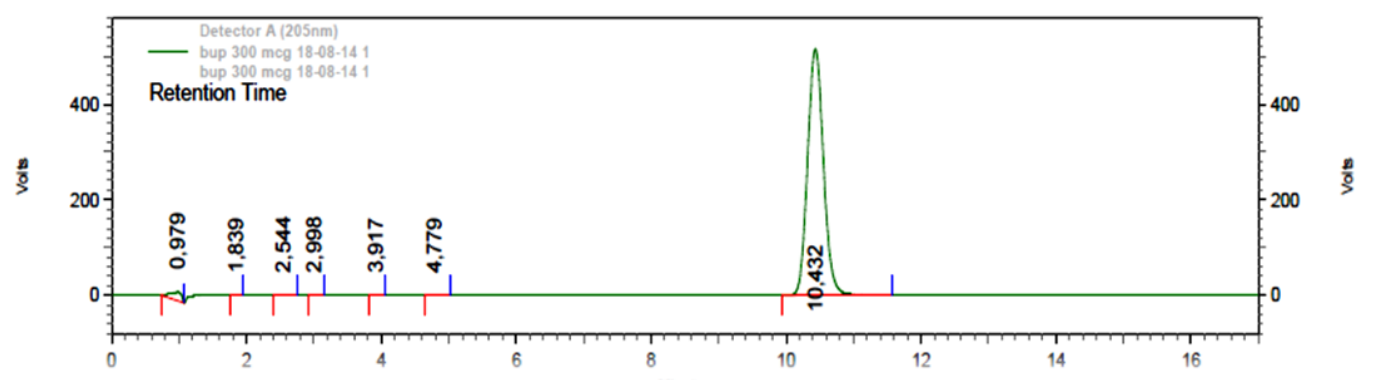

Figura 26 - Cromatograma da solução de cloridrato de bupivacaína $300 \mu \mathrm{g} \mathrm{m}^{-1}$; Condições: Coluna Gemini $C_{18}(5 \mu \mathrm{m}, 150 \times 4,6 \mathrm{~mm})$, vazão: $1,5 \mathrm{~mL} \mathrm{~min}^{-1}$, fase móvel: ACN : Tris Buffer 45:55, pH 7,9 ajustado com ácido clorídrico 1M; detecção UV de 205 nm.

Observa-se que os tempos de retenção do princípio ativo apresentaram-se bastante próximos, o que torna a caracterização da substância pelo método analítico bastante característico e coerentes com os resultados encontrados na literatura. 


\title{
8.3 LIMITES DE DETECÇÃO E LIMITES DE QUANTIFICAÇÃO
}

De acordo com a RE nํ99, de 29 de maio de 2003 da Agência Nacional de Vigilância Sanitária [73]:

\begin{abstract}
Limite de detecção é a menor quantidade do analito presente em uma amostra que pode ser detectado, porém não necessariamente quantificado, sob as condições experimentais estabelecidas. O limite de detecção é estabelecido por meio da análise de soluções de concentrações conhecidas e decrescentes do analito, até o menor nível detectável.
\end{abstract}

No caso de métodos não instrumentais (CCD, titulação, comparação de cor), esta determinação pode ser feita visualmente, onde o limite de detecção é o menor valor de concentração capaz de produzir o efeito esperado (mudança de cor, turvação, etc.).

No caso de métodos instrumentais (CLAE, CG, absorção atômica), a estimativa do limite de detecção pode ser feita com base na relação de 3 vezes o ruído da linha de base. Pode ser determinado pela equação,

$$
L D=\underline{D P_{a}} \times \underline{3}
$$

IC

em que: DPa é o Desvio Padrão do intercepto com o eixo do $Y$ de, no mínimo, 3 curvas de calibração construídas contendo concentrações do fármaco próximas ao suposto limite de quantificação. Este desvio padrão pode ainda ser obtido a partir da curva de calibração proveniente da análise de um número apropriado de amostras do branco; IC é a inclinação da Curva de calibração.

E ainda de acordo com a mesma Resolução, Limite de Quantificação

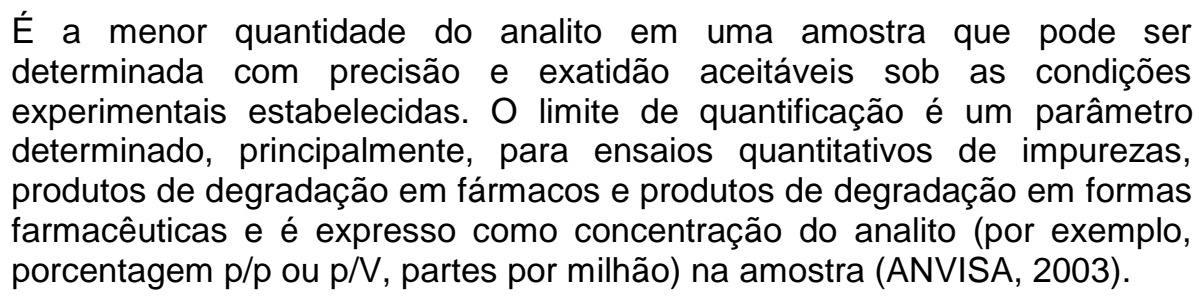

O limite de quantificação é estabelecido por meio da análise de soluções contendo concentrações decrescentes do fármaco até o menor nível determinável com precisão e exatidão aceitáveis. Pode ser expresso pela equação, 


\section{$\mathrm{LD}=\underline{\mathrm{DPa} X 3}$}

IC

em que: DPa é o desvio padrão do intercepto com o eixo do $Y$ de, no mínimo, 3 curvas de calibração construídas contendo concentrações do fármaco próximas ao suposto limite de quantificação. Este desvio padrão pode ainda ser obtido a partir da curva de calibração proveniente da análise de um apropriado número de amostras do branco; IC é a inclinação da curva de calibração.

Análise dos dados experimentais para CLAE:

Analisou-se os resultados obtidos em laboratório para concentrações que variaram entre 50 a $300 \mu \mathrm{g}$ de cloridrato de bupivacaína, os resultados e a curva de linearidade são demonstrados a seguir:

Tabela 3 - Tabela de concentração/absorbância em CLAE

\begin{tabular}{cr}
\hline Concentração $(\mu \mathrm{g})$ & Absorbância $(\mathrm{mAu})$ \\
\hline 50 & 1.328 .561 \\
100 & 2.722 .623 \\
150 & 4.402 .850 \\
200 & 6.248 .301 \\
300 & 8.311 .676 \\
\hline
\end{tabular}

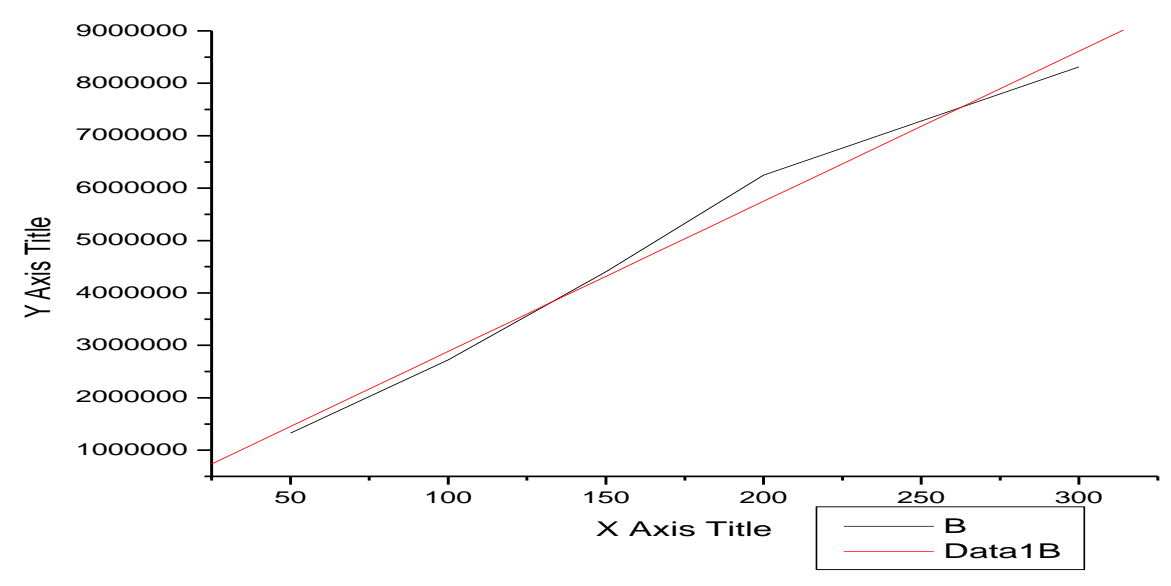

Figura 27 - Curva de Calibração em CLAE do cloridrato de bupivacaína Nota:Gráfico concentração $(\mu \mathrm{g})$ xabsorbância(mAu) 


\begin{tabular}{|c|c|c|c|}
\hline \multicolumn{4}{|c|}{ [11/3/2014 10:58 "/Graph1" (2456964)] } \\
\hline \multirow{2}{*}{\multicolumn{4}{|c|}{$\begin{array}{l}\text { Linear Regression for Data1_B: } \\
Y=A+B * X\end{array}$}} \\
\hline & & & \\
\hline & ter & Value & Error \\
\hline A & \multicolumn{2}{|c|}{18850.75676} & 340208.31373 \\
\hline B & \multicolumn{2}{|c|}{28649.70027} & 1872.78513 \\
\hline $\mathrm{R}$ & SD & $\mathrm{N}$ & $P$ \\
\hline & & 36023 & 7.412425 \\
\hline
\end{tabular}

Observa-se excelente correlação entre concentração e resposta da técnica utilizada, com $\mathrm{R}=0,99365$.

A partir dos dados obtidos através da média de 3 curvas analíticas, calcula-se os limites de detecção e quantificação:

Dados: $S D=360237,41 \mathrm{IC}=28649,70$
$\mathrm{LD}=3 . \mathrm{SD} / \mathrm{IC}=3.360237,41 / 28649,70=37,72$

E o limite de quantificação:

$L Q=10 . S D / I C=10.360237,41 / 28649,70=125,74$

\subsection{VALIDAÇÃO DA METODOLOGIA}

Verificações precisam ser realizadas para garantir que as características de desempenho de um método sejam entendidas e para demonstrar que o método seja cientificamente coerente, sob as condições nas quais ele deve ser aplicado. Essas verificações são coletivamente conhecidas como validação. A validação de um método estabelece, através de estudos sistemáticos de laboratório, que o método é adequado á finalidade, isto é, suas características de desempenho são capazes de produzir resultados correspondentes às necessidades do problema analítico [71]. 
Linearidade: Através da análise da curva analítica, que define a resposta do instrumento e a concentração conhecida do analito, no intervalo de 50 a $300 \mu \mathrm{g}$, observou-se boa linearidade do método ( $R$ de 0,99365$)$.

Precisão: O método desenvolvido por CLAE apresentou-se preciso, onde os valores das medidas apresentaram pequena variação do tempo de retenção e resposta do equipamento, onde os níveis de absorbância detectados pelo detector UV-Vis respeitaram os diferentes níveis de concentração do princípio ativo. No entanto, deve-se salientar a necessidade de preparação diária da fase móvel, pois devido ao fato da fase orgânica ser potencialmente volátil, pode gerar diferenças no tempo de retenção das amostras em diferentes datas.

Exatidão: o método desenvolvido por CLAE apresentou-se exato, os valores obtidos nas análises apresentaram-se bastante coerentes com os resultados descritos na literatura.

Robustez: O método apresentou-se robusto, porém, deve-se observar a necessidade de análise prévia da fase móvel, com rígido controle de $\mathrm{PH}$, pois variações neste parâmetro físico-químico gera diferenças significativas do tempo de retenção das amostras, além da composição da fase móvel, onde as concentrações da fase aquosa e orgânica devem estar relativamente constantes. 


\section{ANÁLISE DO MEDICAMENTO INDUSTRIAL POR CROMATOGRAFIA LÍQUIDA DE ALTA EFICIÊNCIA}

Tendo por base os cromatogramas obtidos previamente pelo pós-Graduando a partir do padrão do princípio ativo Cloridrato de Bupivacaína, realizou-se testes com o medicamento Industrializado fornecido pelo laboratório farmacêutico fabricante.

O medicamento, conforme descrição da bula, possui uma concentração de 5 $\mathrm{mg} / \mathrm{mL}$ do princípio ativo na solução injetável.

Procede-se as diluições para concentrações a 100, 200 e $300 \mu \mathrm{g} / \mathrm{mL}$ e posterior análise em HPLC, obtendo-se os seguintes cromatogramas:

\section{Cromatograma 1 do medicamento industrial, $100 \mu \mathrm{g} / \mathrm{mL}$}

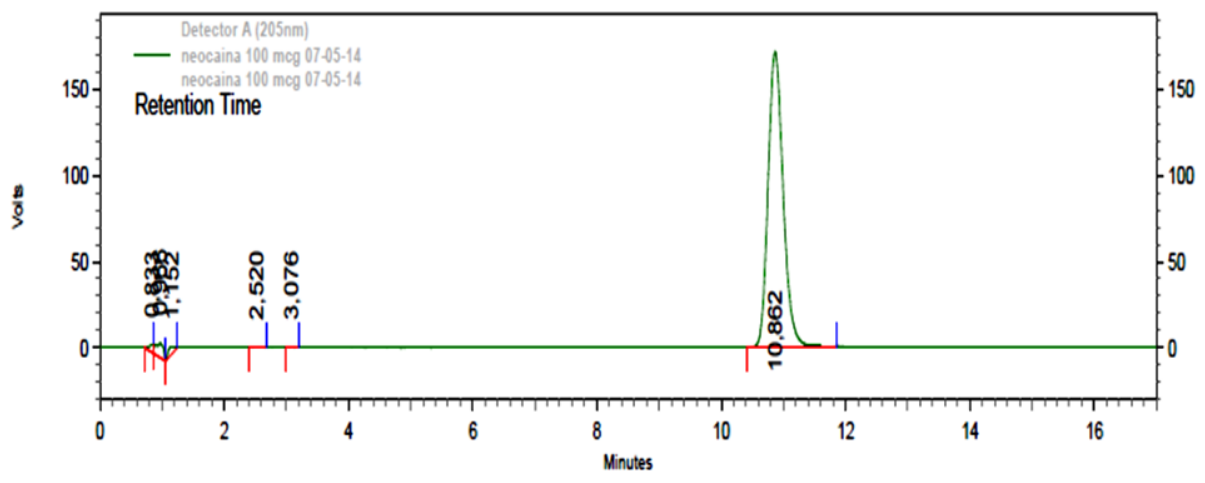

Figura 28 - Cromatograma da solução do medicamento industrial $100 \mu \mathrm{g} \mathrm{mL}^{-1}$; Condições: Coluna Gemini $C_{18}(5 \mu \mathrm{m}, 150 \times 4,6 \mathrm{~mm})$, vazão: $1,5 \mathrm{~mL} \mathrm{~min}^{-1}$, fase móvel: ACN : Tris Buffer 45:55, pH 7,9 ajustado com ácido clorídrico 1M; detecção UV de 205 nm. 


\section{Cromatograma 2 do medicamento industrial, $200 \mu \mathrm{g} / \mathrm{mL}$}

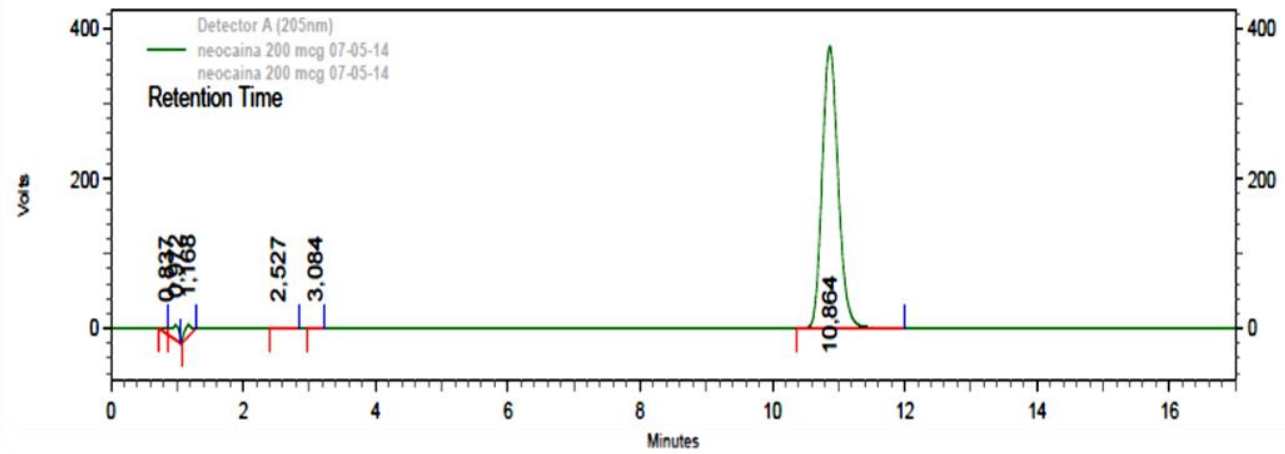

Figura 29 - Cromatograma da solução do medicamento industrial $200 \mu \mathrm{g} \mathrm{mL}^{-1}$; Condições: Coluna Gemini $C_{18}(5 \mu \mathrm{m}, 150 \times 4,6 \mathrm{~mm})$, vazão: $1,5 \mathrm{~mL} \mathrm{~min}^{-1}$, fase móvel: ACN : Tris Buffer 45:55, pH 7,9 ajustado com ácido clorídrico 1M; detecção UV de $205 \mathrm{~nm}$.

\section{Cromatograma3 do medicamento industrial, $300 \mu \mathrm{g} / \mathrm{mL}$}

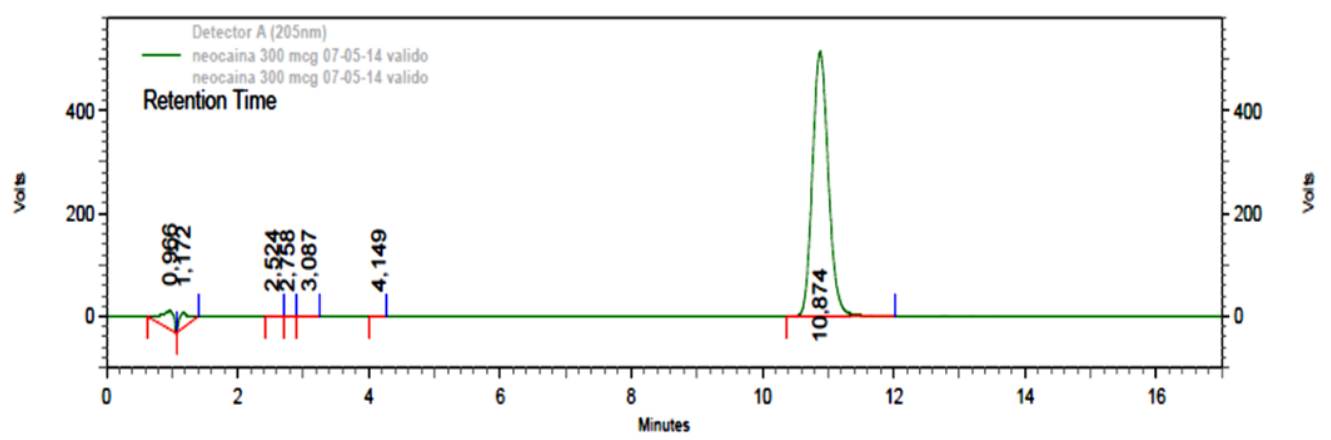

Figura 30 - Cromatograma da solução do medicamento industrial $300 \mu \mathrm{g} \mathrm{mL}^{-1}$; Condições: Coluna Gemini $C_{18}(5 \mu \mathrm{m}, 150 \times 4,6 \mathrm{~mm})$, vazão: $1,5 \mathrm{~mL} \mathrm{~min}^{-1}$, fase móvel: ACN : Tris Buffer 45:55, pH 7,9 ajustado com ácido clorídrico 1M; detecção UV de 205 nm.

Os resultados obtidos demonstram que o medicamento industrial contém a quantidade indicada na bula do princípio ativo. 


\section{CINÉTICA QUÍMICA E CONTROLE DA QUALIDADE DE MEDICAMENTOS}

A cinética química ocupa-se fundamentalmente com a velocidade com que ocorrem os processos químicos e, por isto, a variável tempo ocupa um papel central. O estudo da cinética das reações químicas tem por objetivo a correlação matemática de dados experimentais, visando estabelecer hipóteses sobre os fatores determinantes da velocidade de uma reação e elucidar os mecanismos de reação envolvidos [21].

A cinética química constitui-se em um campo extremamente vasto, englobando desde a descrição experimental da variação das concentrações de reagentes e produtos com o tempo, estudos mecanísticos de reações químicas e de otimização dos parâmetros que levam um processo de síntese a ser mais efetivo em níveis industriais e laboratorial, até a descrição cinética de processos metabólicos e bioquímicos, entre outros. A determinação dos mecanismos de reação, de vital importância na química orgânica, é feita usando a metodologia da cinética, investigando a influência da temperatura e da concentração dos reagentes na velocidade da reação [21].

No âmbito farmacêutico, a cinética química tem aplicação relevante nos estudos de estabilidade de medicamentos, assim como a caracterização dos mecanismos envolvidos na degradação dos mesmos. O conhecimento de tais aspectos permite estabelecer prazos de validade fidedignos, além de assegurar e otimizar a estabilidade dos medicamentos, detectando incompatibilidades decorrentes da mistura dos produtos ou evitando o efeito tóxico associado a produtos de degradação [21].

Considerando-se a reação genérica:

$$
a \mathrm{~A}+b \mathrm{~B} \rightarrow c \mathrm{C}+d \mathrm{D}
$$

A variação da concentração será negativa (diminuição) nos casos dos reagentes $A$ e $B$, e positiva (aumento) para os produtos $C$ e $D$. Na prática, essa variação pode ser medida por meio de diferentes métodos químicos, físico ou físico-

químicos, como variação de $\mathrm{pH}$, volume, pressão, condutividade, rotação óptica, absorbância e fluorescência, por exemplo [21].

Para fins de análise de estabilidade de medicamentos, é bastante frequente expressar os resultados de um estudo cinético em termos do tempo de reação 
médio ou tempo de meia-vida $\left(\mathrm{t}_{50 \%}\right.$ ou $\left.\mathrm{t}_{1 / 2}\right)$, isto é, o tempo necessário para que a concentração de reagente seja metade do valor inicial. O tempo t90\% $_{9}$ tem um sentido maior nos estudos de estabilidade e indica o tempo necessário para que ocorra uma redução de $10 \%$ da concentração inicial de reagente (medicamento). Para diversos produtos, o $t_{90 \%}$ é preconizado como o limite de degradação máxima que um fármaco pode sofrer, visando à sua utilização pelo paciente [21].

\subsection{MÉTODO DE TRIAGEM PARA A DETERMINAÇÃO DA ESTABILIDADE DE MEDICAMENTOS}

Estudo de estabilidade do programa de desenvolvimento de medicamentos é uma das mais importantes áreas relacionadas ao registro de produtos farmacêuticos. A avaliação da estabilidade começou com estudos nas substâncias para determinar os produtos de degradação e caminhos da degradação. O estudo de estabilidade pode influenciar a especificação, limites e métodos de controle dos fármacos.

A análise térmica é um método de rotina para análise de drogas e substâncias de interesse farmacológico. Calorimetria Diferencial Exploratória / Differential Scarnning Calorimetry é uma das técnicas termo-analíticas usadas para fornecer informações sobre comportamento de fusão, calor de fusão, pureza, polimorfismo, pseudo-polimorfismo, compatibilidade, cristalização e reações químicas das drogas como estabilidade e cinética de decomposição [28]; [29].

Um método em laboratório para determinação da estabilidade de materiais tem como idéia é que muitos processos que interferem na estabilidade exibem um Período de Indução (IP), ou seja, o estágio que precede as principais alterações nos fármacos, no qual, aparentemente não ocorrem alterações físicas ou químicas. Depois da determinação deste Período de Indução, a qualidade das amostras testadas foram dramaticamente mudadas. O método é aplicado para triagem da estabilidade em um grupo de 3 compostos farmacêuticos. Para o grupo de 3compostos testados, a ordem de estabilidade obtida pelo novo método, coincide com a ordem de estabilidade obtida pelos testes clássicos de estabilidade. $O$ método promoveu parâmetros imparciais descrevendo a duração do Período de Indução, o qual pode levar a uma extrapolação confiável dos resultados obtidos desde altas para baixas temperaturas de interesse prático [27]. 


\title{
10.2 TESTES DE DEGRADAÇÃO
}

\subsubsection{Ensaios de estabilidade de medicamentos}

\begin{abstract}
Estabilidade é definida como a extensão em que um produto retém, dentro dos limites especificados e dentro do período de armazenagem e de uso (isto é, prazo de validade), as mesmas propriedades e características que possuía na ocasião em que foi fabricado [24].
\end{abstract}

Existem cinco tipos de estabilidade importantes para o farmacêutico:

1. Química: Cada ingrediente ativo retém sua integridade química e potência indicadas na embalagem, dentro dos limites especificados.

2. Física: São mantidas as propriedades físicas originais, inclusive aparência, palatabilidade, uniformidade, dissolução e suspensibilidade.

3. Microbiológica: a esterilidade ou resistência ao crescimento microbiano é mantida, de acordo com os requisitos especificados. Os agentes antimicrobianos presentes mantêm a efetividade dentro dos limites determinados.

4. Terapêutica: $O$ efeito terapêutico permanece inalterado.

5. Toxicológico: Não ocorre aumento significante na toxicicidade[24].

O objetivo dos estudos realizados dentro da Faculdade de Ciências Farmacêuticas da Universidade de São Paulopelo mestrando concentra-se nas características físico-químicas do medicamento.

As condições externas envolvidas na deteriorização de fármacos e medicamentos são tidas como fatores extrínsecos ou ambientais, dentre estes, citase a luz, o ar e a umidade [6]

Os principais processos de degradação química são a hidrólise, oxidação, reações fotoquímicas, isomerização e polimerização. A maior ou menor vulnerabilidade de uma espécie sofrer uma reação química é definida como fator intrínseco de estabilidade. Outros fatores intrínsecos são aqueles associados às propriedades físico-químicas, tais como ponto de fusão e coeficiente de solubilidade [6]. 
Foram realizados testes de degradação forçada em diferentes condições, em meio aquoso, meio neutro, meio ácido e degradação por peróxido de hidrogênio, todos em temperatura a $70^{\circ} \mathrm{C}$ em banho-maria.

\subsubsection{Degradação por hidrólise}

Submeteu-se teste de degradação por hidrolise em janeiro de 2014 a uma concentração de $1000 \mu \mathrm{g} / \mathrm{mL}$ de cloridrato de bupivacaína. A amostra foi colocada em banho-maria a $70^{\circ} \mathrm{C}$ durante $7,14,21$ dias. A partir da solução-mãe, foi preparada amostra a $100 \mu \mathrm{g} / \mathrm{mL}$ em fase móvel de acetonitrila e tampão. Não foram observadas alterações significativas na concentração da substância a partir do ponto zero em todo o período dos testes por análise comparativa em cromatografia líquida de alta eficiência.

\section{Cromatograma hidrólise branco}

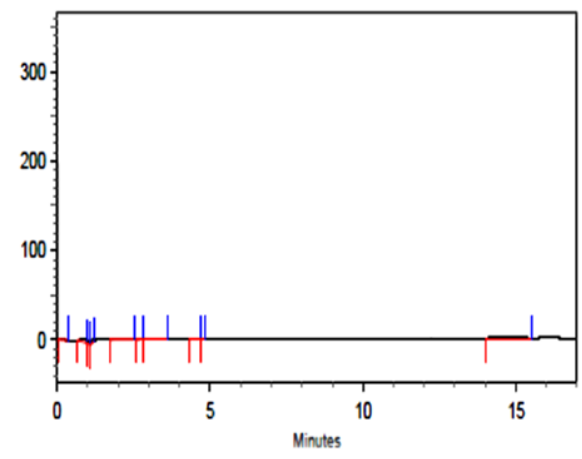

Figura 31 - Cromatograma da solução branco de hidrólise; Condições: Coluna Gemini $\mathrm{C}_{18}(5$ $\mu \mathrm{m}, 150 \times 4,6 \mathrm{~mm}$ ), vazão: $1,5 \mathrm{~mL} \mathrm{~min}{ }^{-1}$, fase móvel: ACN : Tris Buffer 45:55, $\mathrm{pH}$ 7,9 ajustado com ácido clorídrico 1M; detecção UV de $205 \mathrm{~nm}$.

\section{Cromatograma hidrólise ponto zero}

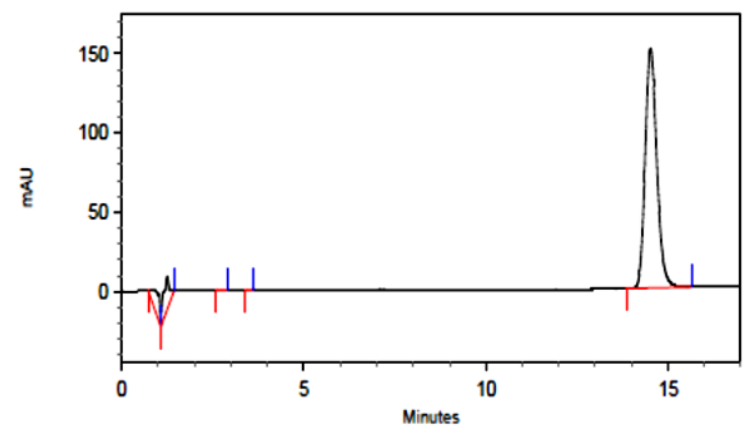

Figura 32 - Cromatograma da solução a $100 \mathrm{\mu g} \mathrm{ml}^{-1}$ de hidrólise ponto zero; Condições: Coluna Gemini $C_{18}(5 \mu \mathrm{m}, 150 \times 4,6 \mathrm{~mm})$, vazão: $1,5 \mathrm{~mL} \mathrm{~min}^{-1}$, fase móvel: ACN : Tris Buffer 45:55, pH 7,9 ajustado com ácido clorídrico 1M; detecção UV de $205 \mathrm{~nm}$. 


\section{Cromatograma hidrólise 7 dias}

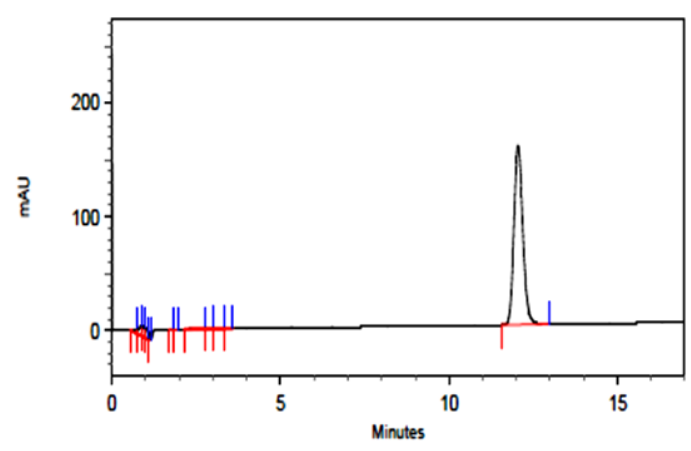

Figura 33 - Cromatograma da solução a $100 \mathrm{gg} \mathrm{ml}^{-1}$ de hidrólise 7 dias; Condições: Coluna Gemini $C_{18}(5 \mu \mathrm{m}, 150 \times 4,6 \mathrm{~mm})$, vazão: $1,5 \mathrm{~mL} \mathrm{~min}^{-1}$, fase móvel: $\mathrm{ACN}$ : Tris Buffer 45:55, $\mathrm{pH}$ 7,9 ajustado com ácido clorídrico 1M; detecção UV de $205 \mathrm{~nm}$.

\section{Cromatograma hidrólise 14 dias}

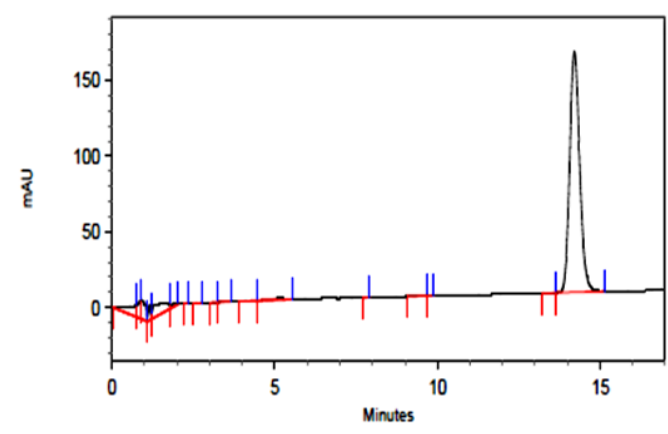

Figura 33 - Cromatograma da solução a $100 \mathrm{\mu g} \mathrm{ml}^{-1}$ de hidrólise 14 dias; Condições: Coluna Gemini $C_{18}(5 \mu \mathrm{m}, 150 \times 4,6 \mathrm{~mm})$, vazão: $1,5 \mathrm{~mL} \mathrm{~min}^{-1}$, fase móvel: $\mathrm{ACN}$ : Tris Buffer 45:55, $\mathrm{pH}$ 7,9 ajustado com ácido clorídrico 1M; detecção UV de $205 \mathrm{~nm}$.

\section{Cromatograma hidrólise 21 dias}

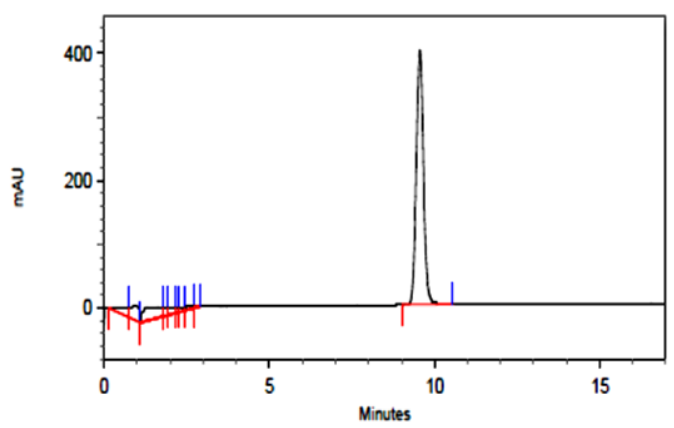

Figura 35 - Cromatograma da solução a $100 \mu \mathrm{g} \mathrm{ml}^{-1}$ de hidrólise 21 dias; Condições: Coluna Gemini $\mathrm{C}_{18}(5 \mu \mathrm{m}, 150 \times 4,6 \mathrm{~mm})$, vazão: $1,5 \mathrm{~mL} \mathrm{~min}^{-1}$, fase móvel: $\mathrm{ACN}$ : Tris Buffer 45:55, $\mathrm{pH}$ 7,9 ajustado com ácido clorídrico 1M; detecção UV de $205 \mathrm{~nm}$. 


\subsubsection{Degradação por hidrólise ácida}

Dando prosseguimento aos testes de degradação, preparou-se amostra também na concentração de $1000 \mu \mathrm{g} / \mathrm{mL}$ de cloridrato de bupivacaína em ácido clorídrico 0,1 M. A amostra foi colocada em banho-maria a $70^{\circ} \mathrm{C}$ durante 7,14 e 21 dias. A partir da solução mãe, foi preparada amostra a $100 \mu \mathrm{g} / \mathrm{mL}$ em fase móvel de acetonitrila e tampão. Não foram observadas alterações significativas na concentração da substância a partir do ponto zero em todo o período dos testes por análise comparativa em cromatografia líquida de alta eficiência.

\section{Cromatograma hidrólise ácida branco}

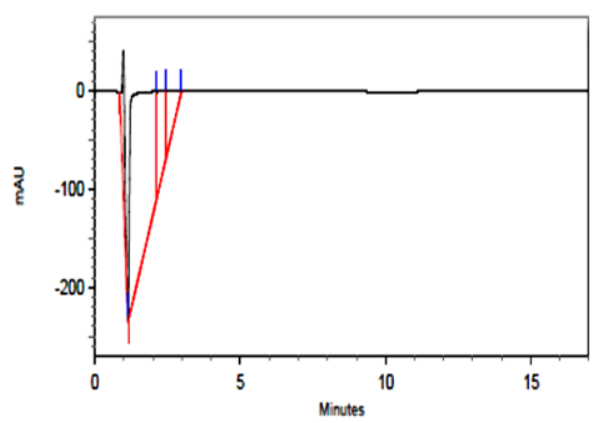

Figura 36 - Cromatograma da solução a $100 \mu \mathrm{g} \mathrm{ml}^{-1}$ de hidrólise ácida branco; Condições: Coluna Gemini $C_{18}(5 \mu \mathrm{m}, 150 \times 4,6 \mathrm{~mm})$, vazão: $1,5 \mathrm{~mL} \mathrm{~min}^{-1}$, fase móvel: ACN : Tris Buffer 45:55, pH 7,9 ajustado com ácido clorídrico 1M; detecção UV de 205 nm.

\section{Cromatograma hidrólise ácida ponto zero}

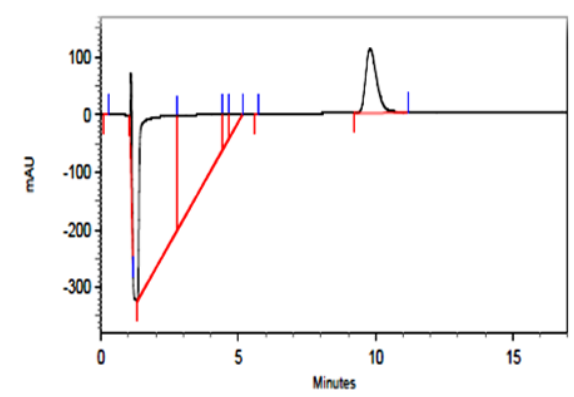

Figura 37 - Cromatograma da solução a $100 \mu \mathrm{g} \mathrm{ml}^{-1}$ de hidrólise ácida ponto zero; Condições: Coluna Gemini $C_{18}\left(5 \mu \mathrm{m}, 150\right.$ x 4,6 mm), vazão: $1,5 \mathrm{~mL} \mathrm{~min}^{-1}$, fase móvel: ACN : Tris Buffer 45:55, pH 7,9 ajustado com ácido clorídrico 1M; detecção UV de $205 \mathrm{~nm}$. 


\section{Cromatograma hidrólise ácida 7 dias}

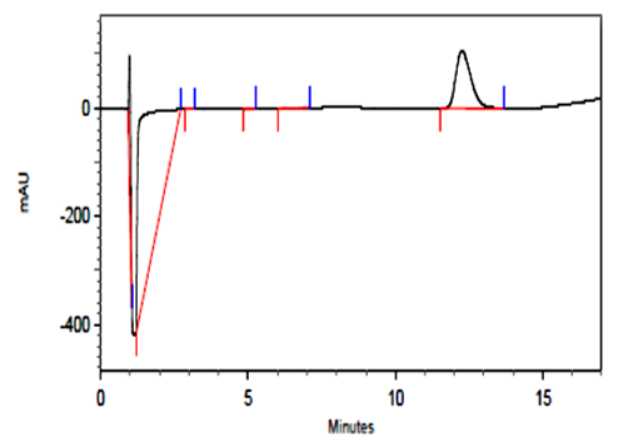

Figura 38 - Cromatograma da solução a $100 \mathrm{gg} \mathrm{ml}^{-1}$ de hidrólise ácida 7 dias; Condições: Coluna Gemini $C_{18}(5 \mu \mathrm{m}, 150 \times 4,6 \mathrm{~mm})$, vazão: $1,5 \mathrm{~mL} \mathrm{~min}^{-1}$, fase móvel: ACN : Tris Buffer 45:55, pH 7,9 ajustado com ácido clorídrico 1M; detecção UV de 205 nm.

\section{Cromatograma hidrólise ácida 14 dias}

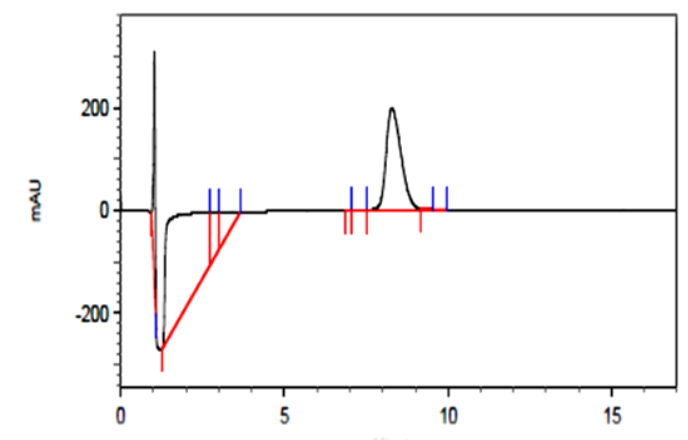

Figura 39 - Cromatograma da solução a $100 \mathrm{gg} \mathrm{ml}^{-1}$ de hidrólise ácida 14 dias; Condições: Coluna Gemini $C_{18}(5 \mu \mathrm{m}, 150 \times 4,6 \mathrm{~mm})$, vazão: $1,5 \mathrm{~mL} \mathrm{~min}^{-1}$, fase móvel: ACN : Tris Buffer 45:55, pH 7,9 ajustado com ácido clorídrico 1M; detecção UV de 205 nm.

\section{Cromatograma hidrólise ácida 21 dias}

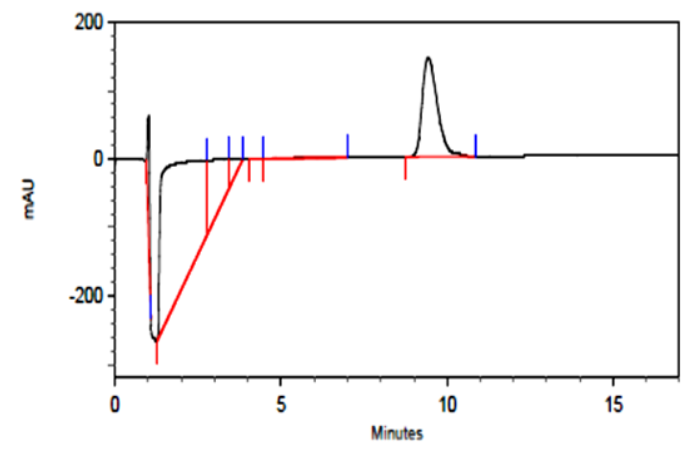

Figura 40 - Cromatograma da solução a $100 \mathrm{~g} \mathrm{ml}^{-1}$ de hidrólise ácida 21 dias; Condições: Coluna Gemini $C_{18}\left(5 \mu \mathrm{m}, 150\right.$ x 4,6 mm), vazão: $1,5 \mathrm{~mL} \mathrm{~min}^{-1}$, fase móvel: ACN : Tris Buffer 45:55, pH 7,9 ajustado com ácido clorídrico 1M; detecção UV de 205 nm. 


\subsubsection{Degradação por oxidação com peróxido de hidrogênio $\left(\mathrm{H}_{2} \mathrm{O}_{2}\right)$}

Foi preparada amostra a $1000 \mu \mathrm{g} \mathrm{mL}^{-1}$ de cloridrato de bupivacaína, com posterior diluição para $100 \mu \mathrm{g} \mathrm{mL}^{-1}$ em peróxido de hidrogênio a 0,3\%. Já na análise do ponto zero, observou-se mudanças nas características da substância, com alterações na concentração e geração de produtos de degradação. A amostra foi submetida ao banho-maria por 7,14 e 21 dias, observando-se alterações ainda mais pronunciadas na sua composição. Conclui-se que a degradação por oxidação possui elevado poder degradante para o cloridrato de bupivacaína.

\section{Cromatograma branco $\mathrm{H}_{2} \mathrm{O}_{2}$}

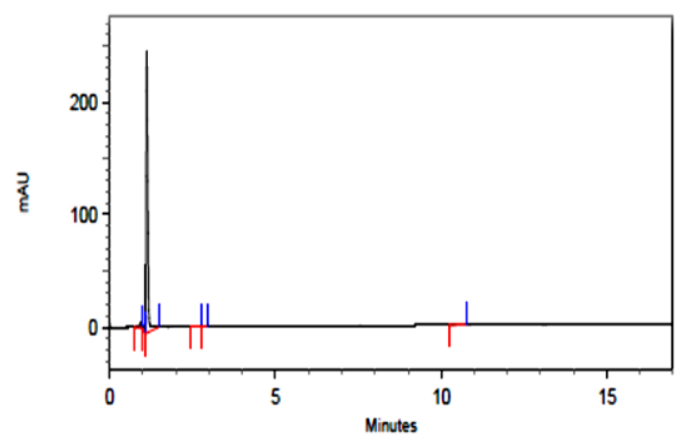

Figura 41 - Cromatograma da solução branco em peróxido de hidrogênio; Condições: Coluna Gemini $C_{18}(5 \mu \mathrm{m}, 150 \times 4,6 \mathrm{~mm})$, vazão: $1,5 \mathrm{~mL} \mathrm{~min}^{-1}$, fase móvel: ACN : Tris Buffer 45:55, pH 7,9 ajustado com ácido clorídrico 1M; detecção UV de $205 \mathrm{~nm}$.

\section{Cromatograma $\mathrm{H}_{2} \mathrm{O}_{2}$ ponto zero}

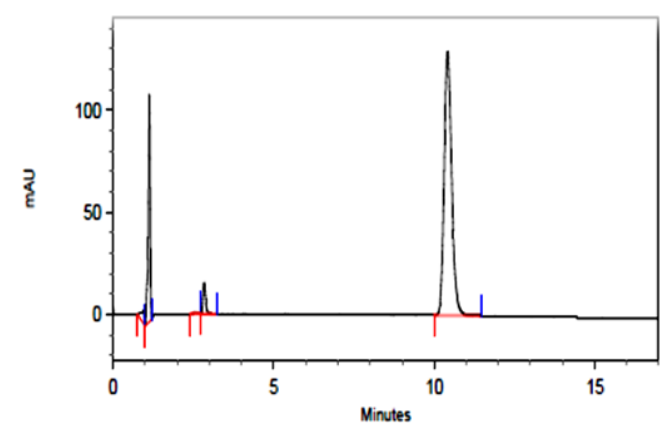

Figura 42 - Cromatograma da solução ponto zero a $100 \mu \mathrm{g} \mathrm{mL}^{-1}$ em peróxido de hidrogênio; Condições: Coluna Gemini $\mathrm{C}_{18}(5 \mu \mathrm{m}, 150 \times 4,6 \mathrm{~mm})$, vazão: $1,5 \mathrm{~mL} \mathrm{~min}^{-1}$, fase móvel: ACN : Tris Buffer 45:55, pH 7,9 ajustado com ácido clorídrico 1M; detecção UV de 205 nm. 


\section{Cromatograma $\mathrm{H}_{2} \mathrm{O}_{2} 7$ dias}

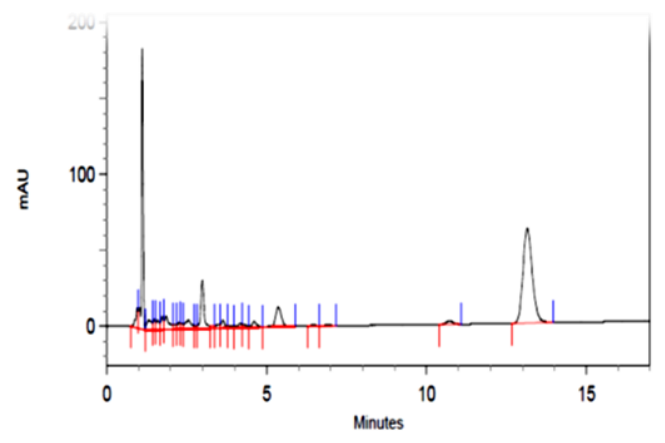

Figura 43 - Cromatograma da solução a 7 dias a $100 \mu \mathrm{g} \mathrm{mL}^{-1}$ em peróxido de hidrogênio; Condições: Coluna Gemini $C_{18}(5 \mu \mathrm{m}, 150 \times 4,6 \mathrm{~mm})$, vazão: $1,5 \mathrm{~mL} \mathrm{~min}^{-1}$, fase móvel: $A C N$ : Tris Buffer 45:55, pH 7,9 ajustado com ácido clorídrico 1M; detecção UV de 205 nm.

\section{Cromatograma $\mathrm{H}_{2} \mathrm{O}_{2} 14$ dias}

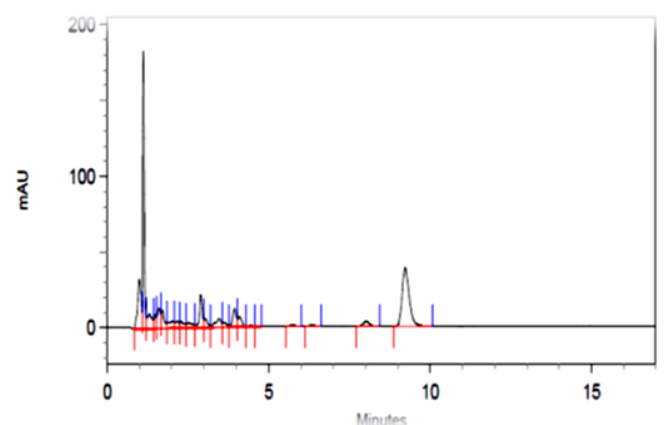

Figura 44.Cromatograma da solução a 14 dias a $100 \mu \mathrm{g} \mathrm{mL}^{-1}$ em peróxido de hidrogênio; Condições: Coluna Gemini $C_{18}(5 \mu \mathrm{m}, 150 \times 4,6 \mathrm{~mm})$, vazão: $1,5 \mathrm{~mL} \mathrm{~min}^{-1}$, fase móvel: $A C N$ : Tris Buffer 45:55, pH 7,9 ajustado com ácido clorídrico 1M; detecção UV de 205 nm.

\section{Cromatograma21 dias}

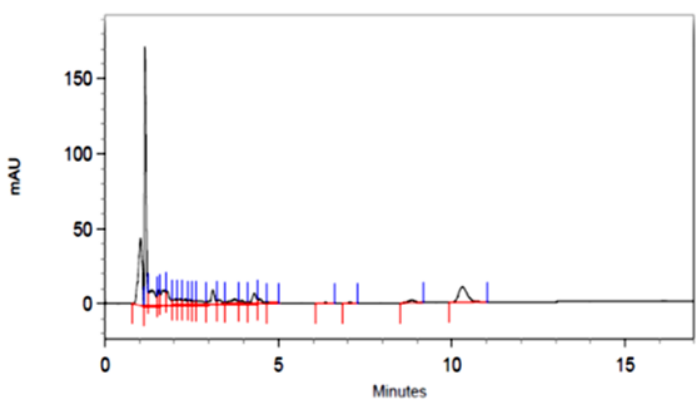

Figura 45 -Cromatograma da solução a 21 dias a $100 \mu \mathrm{g} \mathrm{mL}^{-1}$ em peróxido de hidrogênio; Condições: Coluna Gemini $\mathrm{C}_{18}(5 \mu \mathrm{m}, 150 \times 4,6 \mathrm{~mm})$, vazão: $1,5 \mathrm{~mL} \mathrm{~min}^{-1}$, fase móvel: $A C N$ : Tris Buffer 45:55, pH 7,9 ajustado com ácido clorídrico 1M; detecção UV de 205 nm. 


\subsubsection{Teste de fotoestabilidade}

Foi preparada solução aquosa de cloridrato de bupivacaína a $1000 \mu \mathrm{g} / \mathrm{mL}$ para realização do teste de fotodegradação, a partir desta solução preparou-se as soluções a $100 \mu \mathrm{g} / \mathrm{mL}$ antes e depois de 60 horas de exposição na câmara de fotoestabilidade na semi-industrial da FCF/USP. Observando-se os resultados, não observou-se significativa degradação do princípio ativo, concluindo-se que o a substância pode ser considerada fotoestável.

\section{Cromatograma branco fotólise}

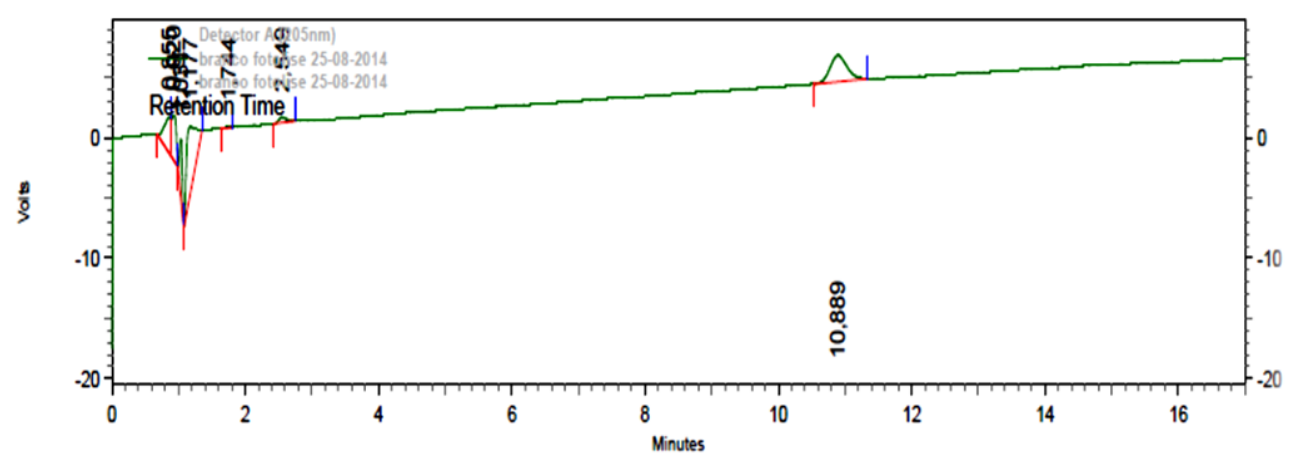

Figura 46 - Cromatograma da solução branco fotólise; Condições: Coluna Gemini $\mathrm{C}_{18}(5$ $\mu \mathrm{m}, 150 \times 4,6 \mathrm{~mm}$ ), vazão: $1,5 \mathrm{~mL} \mathrm{~min}^{-1}$, fase móvel: ACN : Tris Buffer 45:55, $\mathrm{pH}$ 7,9 ajustado com ácido clorídrico 1M; detecção UV de 205 nm.

\section{Cromatograma ponto zero fotólise}

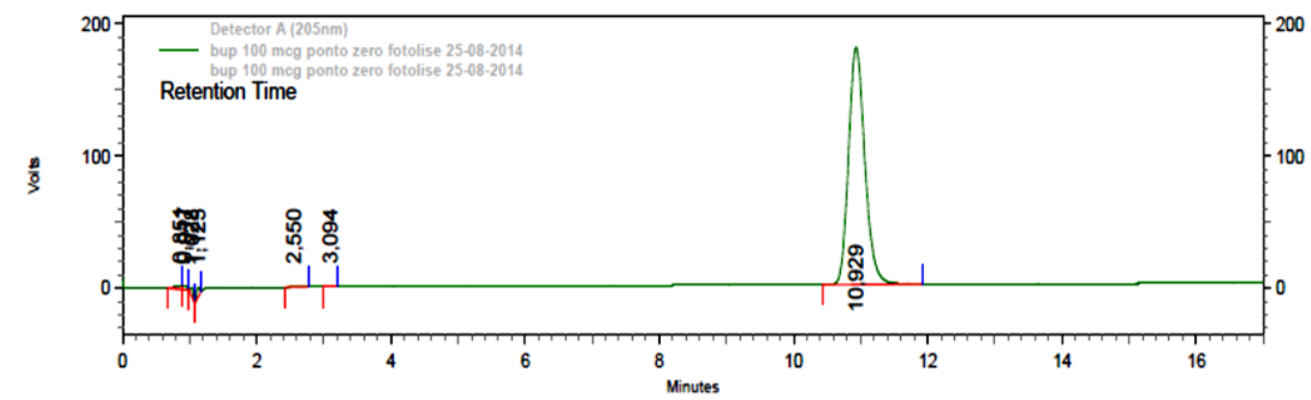

Figura 47 - Cromatograma o ponto zero fotólise; Condições: Coluna Gemini $\mathrm{C}_{18}(5 \mu \mathrm{m}, 150 \mathrm{x}$ 4,6 mm), vazão: $1,5 \mathrm{~mL} \mathrm{~min}^{-1}$, fase móvel: ACN : Tris Buffer 45:55, $\mathrm{pH}$ 7,9 ajustado com ácido clorídrico 1M; detecção UV de $205 \mathrm{~nm}$. 


\section{Cromatograma fotólise solução controle a $100 \mu \mathrm{g} \mathrm{mL}^{-1}$}

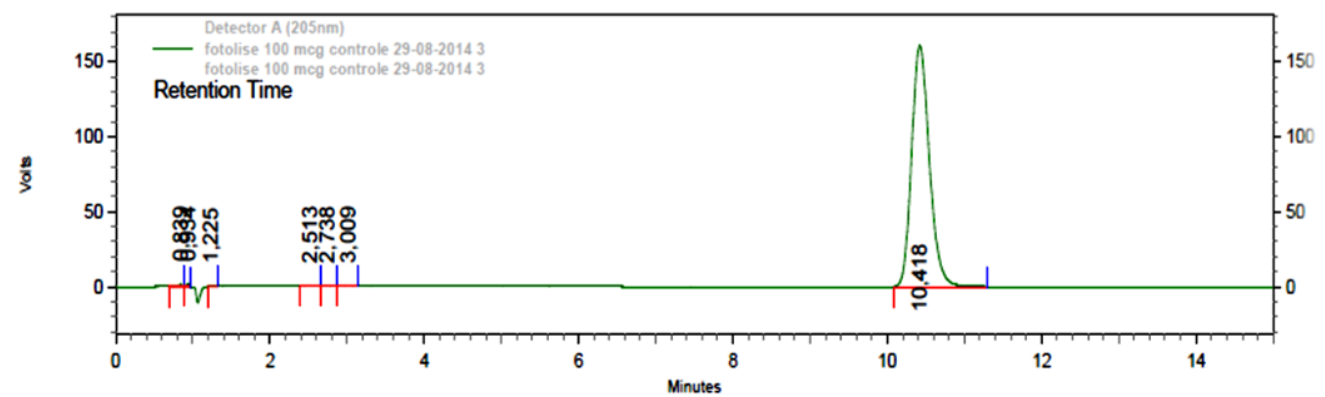

Figura 48 - Cromatograma da solução controle a $100 \mu \mathrm{g} \mathrm{mL}^{-1}$; Condições: Coluna Gemini $\mathrm{C}_{18}$ (5 $\mu \mathrm{m}, 150 \times 4,6 \mathrm{~mm}$ ), vazão: $1,5 \mathrm{~mL} \mathrm{~min}^{-1}$, fase móvel: ACN : Tris Buffer 45:55, $\mathrm{pH}$ 7,9 ajustado com ácido clorídrico 1M; detecção UV de $205 \mathrm{~nm}$.

\section{Cromatograma fotólise solução a $100 \mu \mathrm{g} / \mathrm{mL}$}

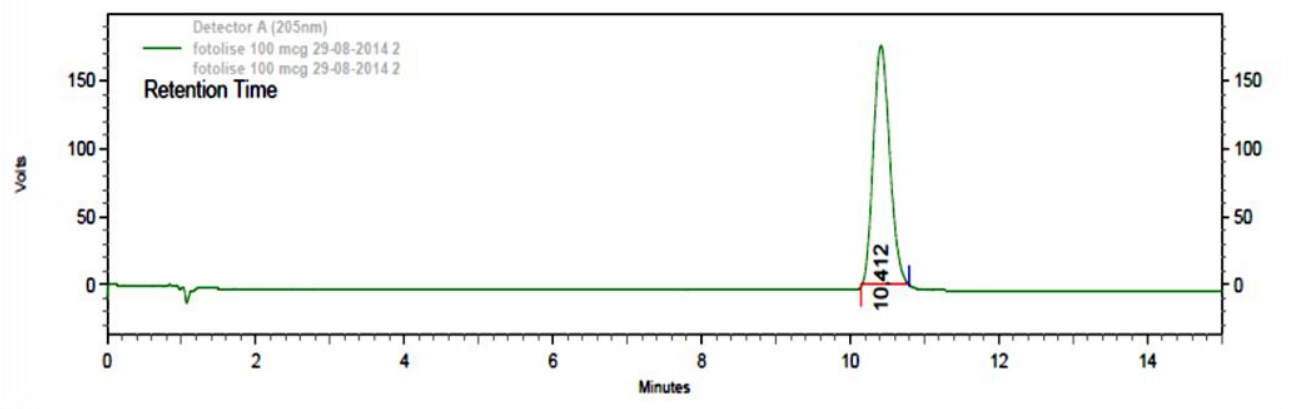

Figura 49 - Cromatograma da solução controle a $100 \mathrm{\mu g} \mathrm{mL}^{-1}$; Condições: Coluna Gemini $\mathrm{C}_{18}$

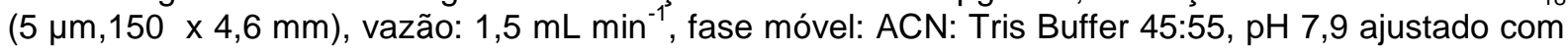
ácido clorídrico 1M; detecção UV de $205 \mathrm{~nm}$.

Todos os testes de degradação estão referenciados em: [55], [56], [57], [58], [59], [60], [61], [62], [63], [64], [65], [66], [67], [68].

\subsubsection{Discussão dos resultados dos testes de degradação}

Fazendo-se uma análise geral dos testes de degradação aos quais foi submetida o princípio ativo do medicamento, conclui-se que o mesmo mostra-se estável às condições adversas. Com exceção do teste com peróxido de hidrogênio, o qual apresentou forte poder degradante com diversos produtos de degradação, os demais testes demonstraram estabilidade da substância, não se verificando uma diminuição significativa da concentração nem produtos de degradação. 


\subsection{APLICAÇÃO DA TÉCNICA DE ELETROFORESE CAPILAR}

Com o objetivo de conhecer outras metodologias analíticas de análise para caracterização da mesma e comparação com a já tradicional Cromatografia Líquida de Alta Eficiência, o pós-graduando iniciou pesquisas para identificação e quantificação do princípio ativo Cloridrato de Bupivacaína e dos possíveis produtos de degradação através dos padrões analíticos destas impurezas de forma similar a realizada em CLAE.

Deve-se salientar, no entanto, que as técnicas possuem características distintas, a Eletroforese Capilar, tem por base a identificação dos compostos por diferentes tempos de migração através de uma coluna capilar sob a qual é aplicada uma diferença de potencial.

O eletrólito, foi composto de Trietanolamina, inicialmente utilizou-se a concentração de $90 \mathrm{mM}$ conforme referência obtida em literatura, posteriormente, reajustou-se esta concentração para $70 \mathrm{mM}$ para um melhor nível de intensidade de corrente, por volta de $80 \mu \mathrm{A}$ e voltagem a aproximadamente $14 \mathrm{kV}$, o pH foi ajustado com ácido fosfórico para 3,0, e detector PDA a 200 nm[73].Capilar de sílica fundida de $31,2 \mathrm{~cm}$ de comprimento total e $21 \mathrm{~cm}$ até o detector.As análises apresentaram os seguintes resultados:

\section{Branco da solução eletrolítica para EC}

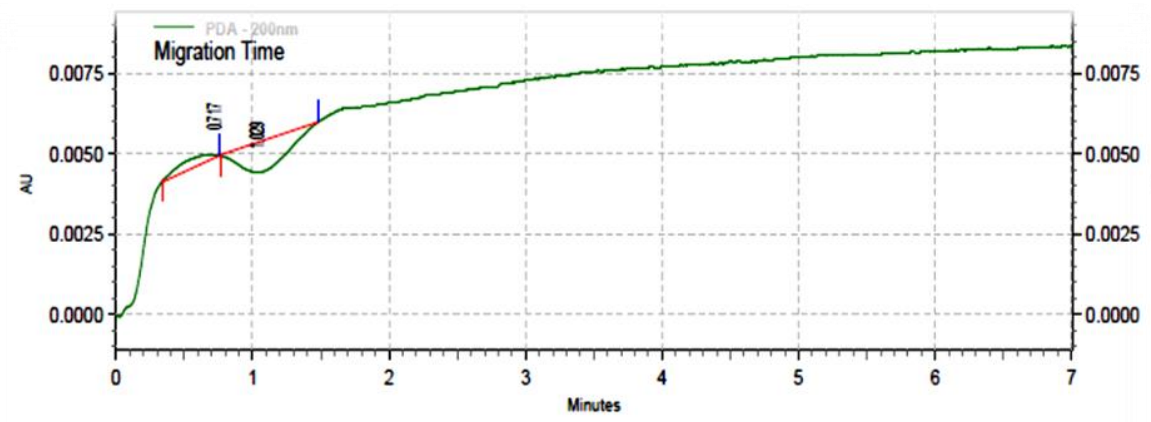

Figura 50 - Eletroferograma do Branco da solução eletrolítica para EC. Eletrólito de corrida de trietanolamina na concentração de $70 \mathrm{mM}$. Condições: voltagem a $14,1 \mathrm{kV}$, temperatura $25^{\circ} \mathrm{C}$, corrente a $80 \mu$ A.Detector PDA a $200 \mathrm{~nm}$. 


\section{Princípio ativo a $50 \mu \mathrm{g} / \mathrm{mL}$}

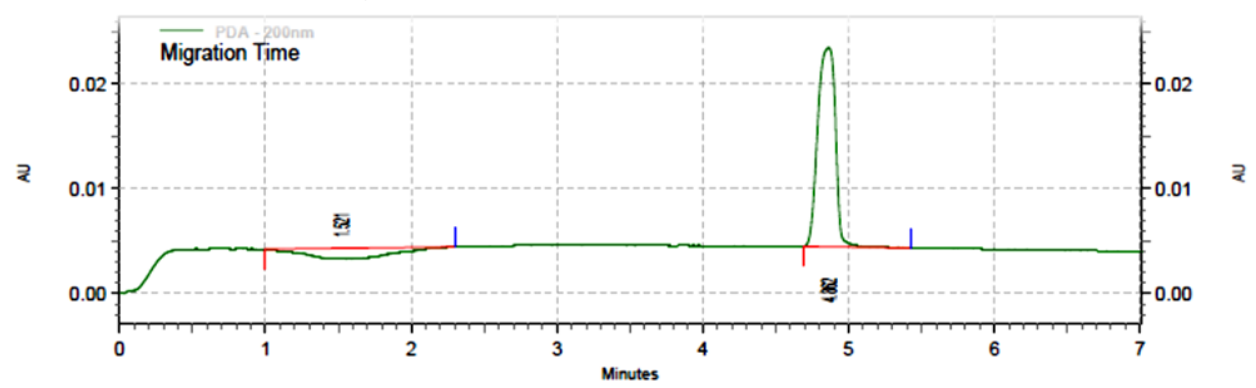

Figura 51 - Eletroferograma do princípio ativo a $50 \mu \mathrm{g} \mathrm{mL}^{-1}$. Eletrólito de corrida de trietanolamina na concentração de $70 \mathrm{mM}$. Condições: voltagem a $14,1 \mathrm{kV}$, temperatura $25^{\circ} \mathrm{C}$, corrente a $80 \mu \mathrm{A}$. Detector PDA a $200 \mathrm{~nm}$.

\section{Princípio ativo a $100 \mu \mathrm{g} / \mathrm{mL}$}

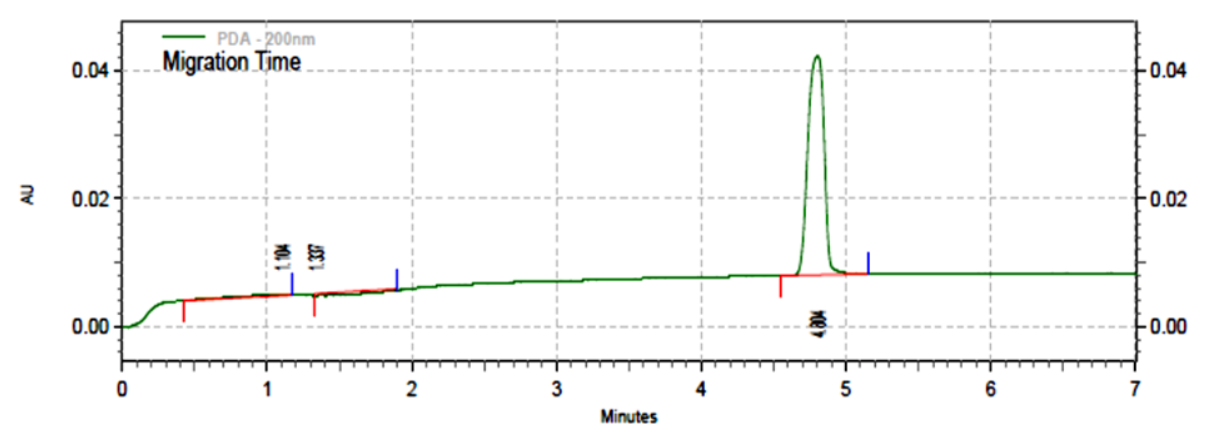

Figura 52 - Eletroferograma do princípio ativo a $100 \mu \mathrm{g} \mathrm{mL} \mathrm{L}^{-1}$. Eletrólito de corrida de trietanolamina na concentração de $70 \mathrm{mM}$. Condições: voltagem a $14,1 \mathrm{kV}$,temperatura $25^{\circ} \mathrm{C}$, corrente a $80 \mu$ A.Detector PDA a $200 \mathrm{~nm}$.

\section{Princípio ativo a $150 \mu \mathrm{g} / \mathrm{mL}$}

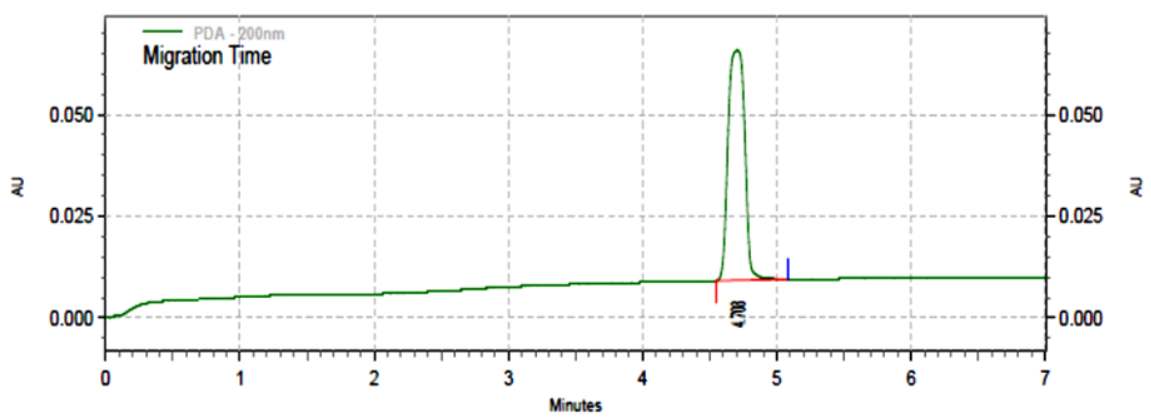

Figura 53 - Eletroferograma do princípio ativo a $150 \mu \mathrm{g} \mathrm{mL}^{-1}$ Eletrólito de corrida de trietanolamina na concentração de $70 \mathrm{mM}$. Condições: voltagem a $14,1 \mathrm{kV}$, temperatura $25^{\circ} \mathrm{C}$, corrente a $80 \mu$ A.Detector PDA a $200 \mathrm{~nm}$. 


\section{Princípio ativo a $200 \mu \mathrm{g} \mathrm{mL}^{-1}$}

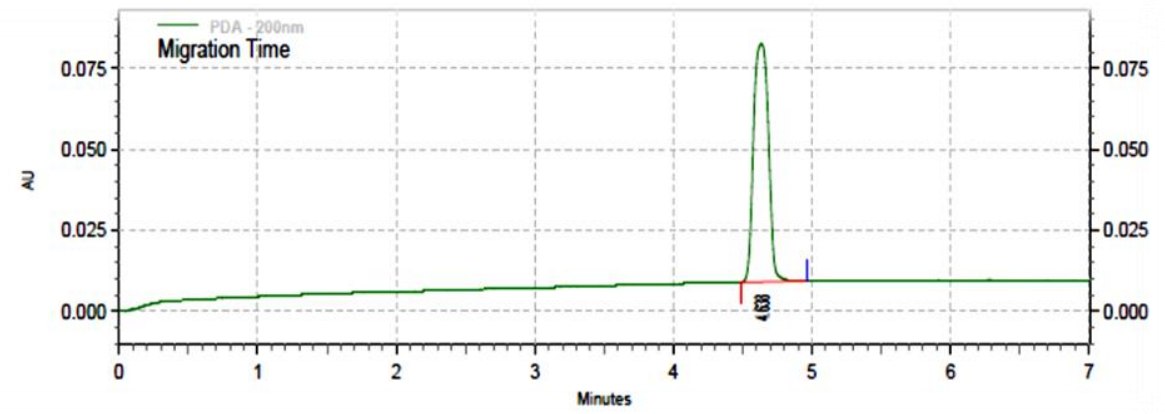

Figura 54 - Eletroferograma do princípio ativo a $200 \mu \mathrm{gmL}^{-1}$.Eletrólito de corrida de trietanolamina na concentração de $70 \mathrm{mM}$. Condições: voltagem a $14,1 \mathrm{kV}$, temperatura $25^{\circ} \mathrm{C}$, corrente a $80 \mu \mathrm{A}$. Detector PDA a $200 \mathrm{~nm}$.

\section{Princípio ativo a $300 \mu \mathrm{g} \mathrm{mL}$}

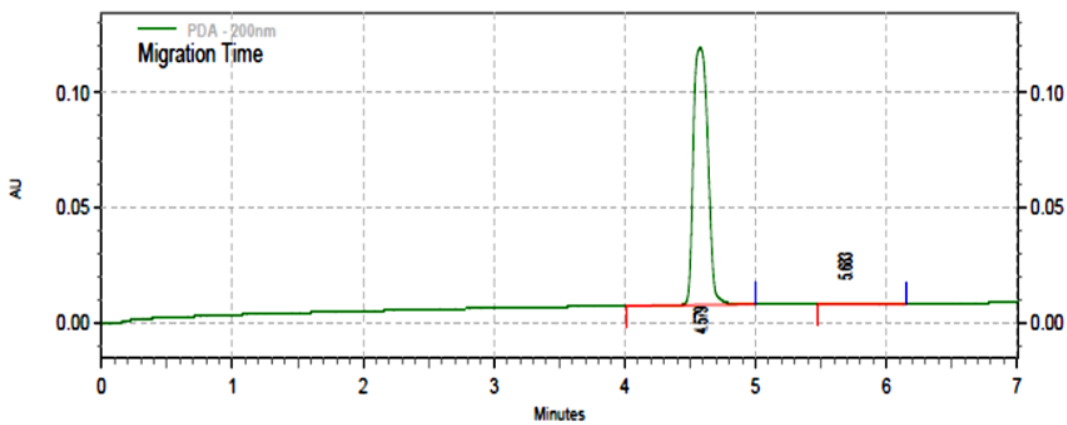

Figura 55 - Eletroferograma do princípio ativo a $300 \mu \mathrm{g} \mathrm{mL} \mathrm{m}^{-1}$.Eletrólito de corrida de trietanolamina na concentração de $70 \mathrm{mM}$. Condições: voltagem a $14,1 \mathrm{kV}$,temperatura $25^{\circ} \mathrm{C}$, corrente a $80 \mu$ A.Detector PDA a $200 \mathrm{~nm}$.

\subsubsection{Análise dos padrões analíticos das impurezas por eletroforese capilar}

\section{2,6 DMA a $20 \mu \mathrm{g} \mathrm{mL}^{-1}$}

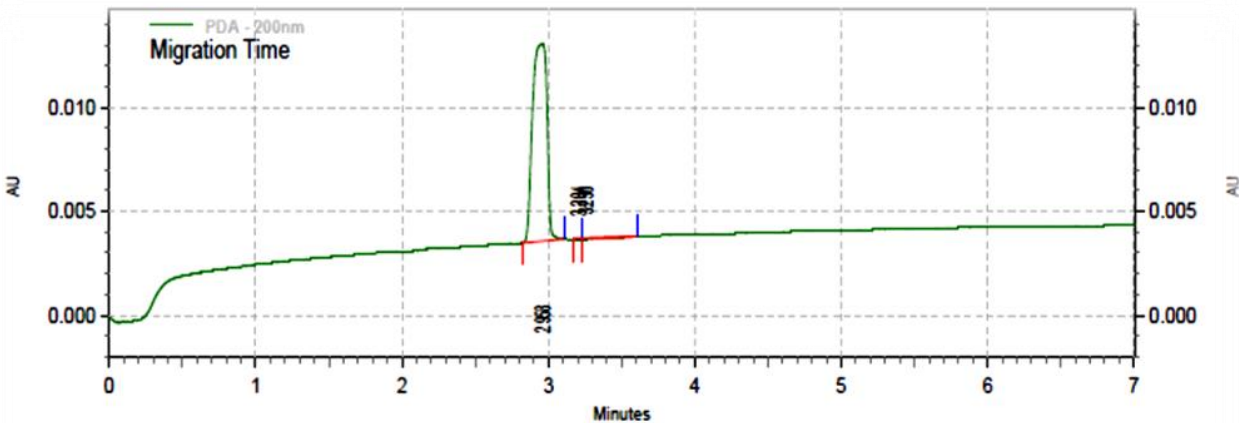

Figura 56 - Eletroferograma do padrão de 2,6 DMA a $20 \mu \mathrm{g} \mathrm{mL}^{-1}$ Eletrólito de corrida de trietanolamina na concentração de $70 \mathrm{mM}$. Condições: voltagem a $14,1 \mathrm{kV}$,temperatura $25^{\circ} \mathrm{C}$, corrente a $80 \mu$ A.Detector PDA a $200 \mathrm{~nm}$. 


\section{$0-T L D 20 \mu \mathrm{g} / \mathrm{mL}$}

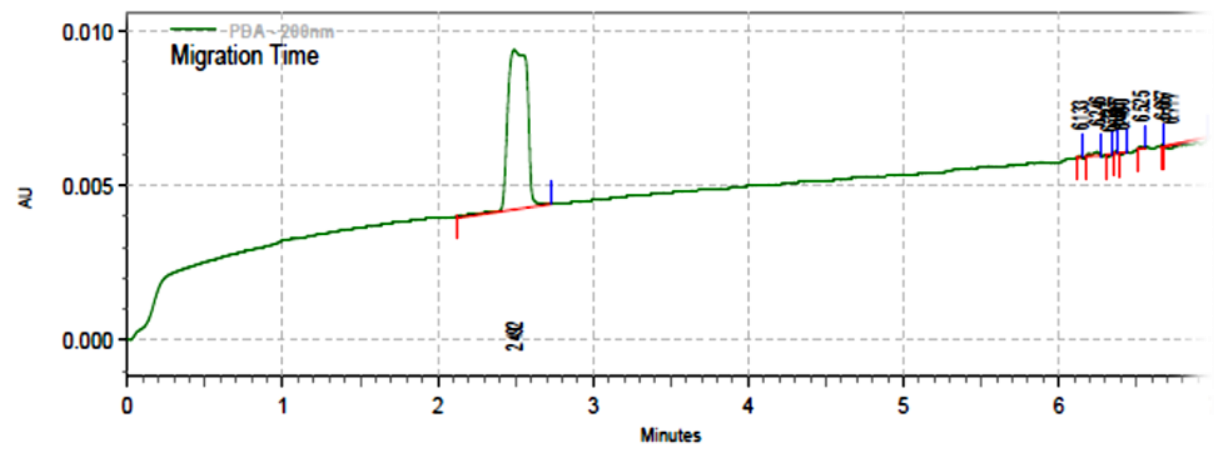

Figura 57 - Eletroferograma do padrão de o-TLD $20 \mu \mathrm{g} / \mathrm{mL}$.Eletrólito de corrida de trietanolamina na concentração de $70 \mathrm{mM}$. Condições: voltagem a $14,1 \mathrm{kV}$,temperatura $25^{\circ} \mathrm{C}$, corrente a $80 \mu$ A.Detector PDA a $200 \mathrm{~nm}$.

Deve-se salientar que os tempos de migração entre os dois padrões de impurezas apresentaram razoável seletividade, já que a estrutura molecular entre os dois é parecida, ficando mais distintos em relação ao princípio ativo

\subsubsection{Análise do medicamento industrial por eletroforese capilar}

Da mesma forma que se procedeu em cromatografia líquida de alta eficiência, o medicamento industrial foi diluído a 3 concentrações a partir da formulação original a $5 \mathrm{mg} / \mathrm{mL}$.

\section{Medicamento a $100 \mu \mathrm{g} \mathrm{mL}^{-1}$}

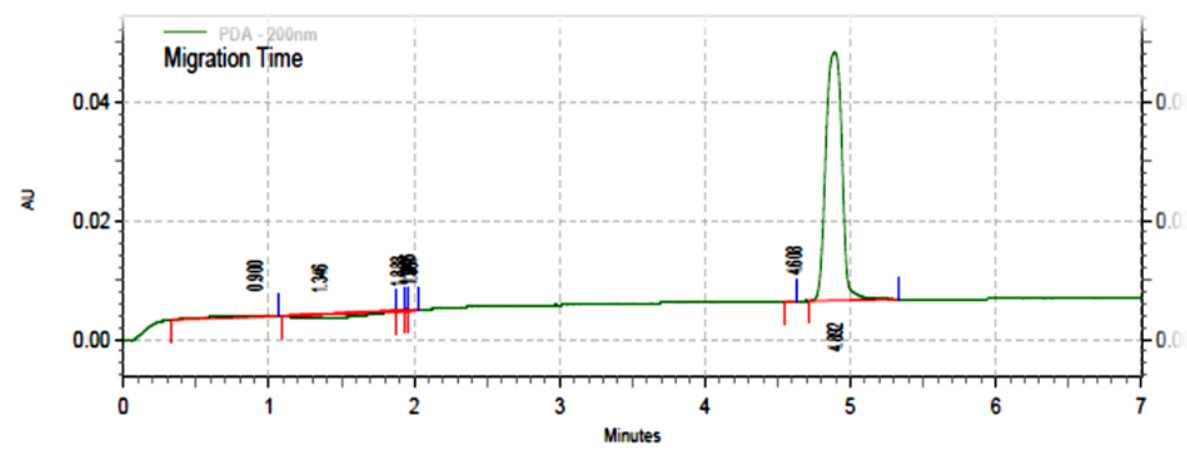

Figura 58 - Eletroferograma do medicamento a $100 \mu \mathrm{g} \mathrm{mL} \mathrm{L}^{-1}$ Eletrólito de corrida de trietanolamina na concentração de $70 \mathrm{mM}$. Condições: voltagem a $14,1 \mathrm{kV}$, temperatura $25^{\circ} \mathrm{C}$, corrente a $80 \mu$ A.Detector PDA a $200 \mathrm{~nm}$. 


\section{Medicamento a $200 \mu \mathrm{gL}^{-1}$}

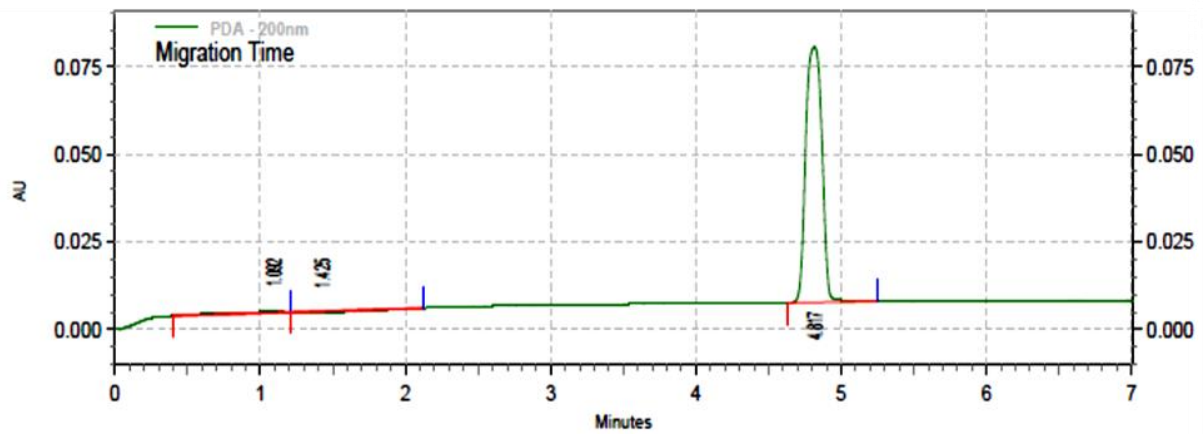

Figura 59 - Eletroferograma do medicamento a $200 \mu \mathrm{g} \mathrm{mL}{ }^{-1}$.Eletrólito de corrida de trietanolamina na concentração de $70 \mathrm{mM}$. Condições: voltagem a $14,1 \mathrm{kV}$, temperatura $25^{\circ} \mathrm{C}$, corrente a $80 \mu \mathrm{A}$. Detector PDA a $200 \mathrm{~nm}$.

\section{Medicamento a $300 \mu \mathrm{g} / \mathrm{mL}$}

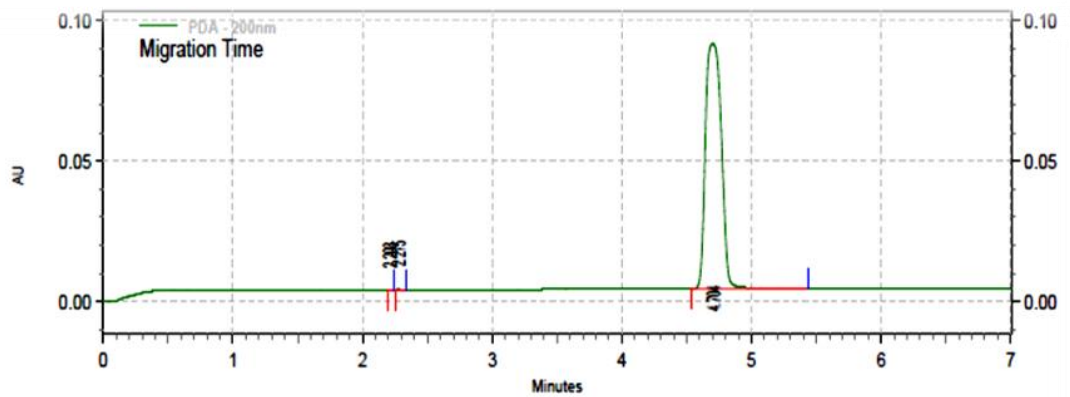

Figura 60 - Eletroferograma do medicamento a $300 \mu \mathrm{g} / \mathrm{mL}$.Eletrólito de corrida de trietanolamina na concentração de $70 \mathrm{mM}$. Condições: voltagem a $14,1 \mathrm{kV}$, temperatura $25^{\circ} \mathrm{C}$, corrente a $80 \mu \mathrm{A}$. Detector PDA a $200 \mathrm{~nm}$.

Comparando-se os tempos de migração do princípio ativo bem como as áreas relativas ás concentrações, conclui-se que o medicamento apresenta-se em conformidade com as especificações descritas na bula. Além disso, não foram observados picos característicos relacionados à presença de quaisquer impurezas intrínsecas ao medicamento. 
10.3.3 Análise dos dados experimentais para EC

Tabela 4 - Concentração/absorbância em EC

\begin{tabular}{cc} 
Concentração $(\mu \mathrm{g})$ & Absorbância $(\mathrm{Au})$ \\
\hline 50 & 126639 \\
100 & 265090 \\
150 & 447628 \\
200 & 546973 \\
300 & 836165 \\
\hline
\end{tabular}

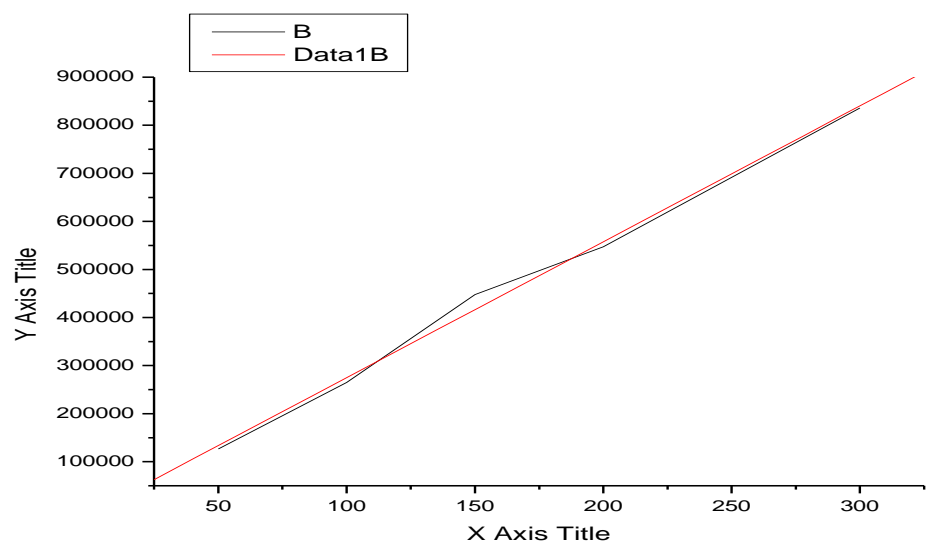

Figura 61 - Curva de calibração para cloridrato de bupivacaína em eletroforese capilar.

$$
\begin{aligned}
& \text { [11/3/2014 11:09 "/Graph1" (2456964)] } \\
& \text { Linear Regression for Data1_B: } \\
& Y=A+B{ }^{*} X \\
& \text { Parameter Value Error }
\end{aligned}
$$$$
\text { A } \quad-7955.27027 \quad 19343.5372
$$$$
\text { B } \quad 2827.83919 \quad 106.48267
$$

\begin{tabular}{lllll}
$R$ & SD & $N$ & & \\
\\
\hdashline .99788 & & 20482.3501 & 5 & $1.17147 \mathrm{E}-4$
\end{tabular}


Nesta técnica, também se constata excelente correlação entre concentração e resposta observada, com $\mathrm{R}=0,99788$.

Dados:

$\mathrm{SD}=20482,35, \mathrm{IC}=2827,84$.

Calcula-se:

$\mathrm{LD}=3 . \mathrm{SD} / \mathrm{IC}=3.20482,35 / 2827,84=21,73 \mu \mathrm{g}$

$\mathrm{LQ}=3 . \mathrm{SD} / \mathrm{IC}=10.20482,35 / 2827,84=72,43 \mu \mathrm{g}$

\subsubsection{Validação da metodologia analítica}

Procedendo-se analogamente a validação para a cromatografia líquida de alto eficiência, verificou-se os mesmos parâmetros para validação da Eletroforese Capilar (EC):

Linearidade: Através da análise da curva analítica, que define a resposta do instrumento e a concentração conhecida do analito, no intervalo de 50 a $300 \mu \mathrm{g}$, observou-se boa linearidade do método ( $\mathrm{R}$ de 0,99788 ).

Precisão: O método desenvolvido por EC apresentou-se preciso, onde os valores das medidas apresentaram pequena variação do tempo de migração e resposta do equipamento, onde os níveis de absorbância detectados pelo detector UV-Vis respeitaram os diferentes níveis de concentração do princípio ativo. Neste sentido, a metodologia de EC apresenta uma vantagem em relação à CLAE, onde a característica do eletrólito, menos volátil que a fase móvel utilizado em CLAE, torna a utilização da solução eletrolítica mais econômica, já que pode ser utilizada em diferentes datas.

Exatidão: o método desenvolvido por EC apresentou-se exato, os valores obtidos nas análises apresentaram-se bastante coerentes com os resultados descritos na literatura, porém, com relação a detecção e quantificação das impurezas não foram descritos parâmetros na literatura, sendo feita uma adaptação da metodologia empregada em CLAE.

Robustez: $O$ método apresentou-se robusto, porém, da mesma forma que ocorreu em CLAE, com rígido controle de $\mathrm{PH}$, pois variações neste parâmetro físicoquímico geram diferenças significativas do tempo de migração das amostras, a 
composição da solução eletrolítica é mais estável que a da fase móvel utilizada em CLAE.

Seletividade:O método mostrou-se razoavelmente seletivo no que diz respeito a detecção do princípio ativo e dos dois padrões de impurezas, porém não tão seletivo na separação dos dois padrões de impurezas entre eles, já que os tempos de migração apresentaram-se relativamente próximos. 


\section{DISCUSSÃO DOS RESULTADOS}

Após a análise dos resultados obtidos pelo pós-graduando durante o período de mestrado na FCF/USP, averiguou-se que em termos gerais o medicamento apresenta-se estável. Não foram observadas alterações significativas nas características do mesmo nos diversos testes de degradação forçada, com exceção do processo de degradação por peróxido de hidrogênio. Mesmo o teste de fotoestabilidade não apresentou significativa degradação ou geração de produtos de degradação. Desde os primeiros testes de identificação e caracterização da substância que se verificou as características de autenticidade e pureza do princípio ativo.

A caracterização das impurezas e do princípio ativo apresentou melhor seletividade na metodologia de cromatografia líquida de alta eficiência, os tempos de retenção entre o princípio ativo e os padrões de impurezas ficaram mais distintos em relação aos eletroferogramas obtidos por Eletroforese Capilar. 


\section{CONCLUSÕES}

Após a realização dos testes de identificação, quantificação e degradação do princípio ativo e do medicamento industrializado, pode-se afirmar com segurança que alcançou-seos principais objetivos da pesquisa.

Verficou-se a pureza do medicamento através dos testes de identificação, incluindo ponto de fusão, Infra-vermelho, UV-Vis, Cromatografia em Camada Delgada e termoanálise.

Não observou-se degradação significativa nos diversos testes de degradação forçada, com exceção da degradação realizado com peróxido de hidrogênio.

Conclui-se que quaisquer desvio de qualidade relacionada a este medicamento não está relacionada a geração de impurezas intrínsecas devido a ausência de produtos de degradação no medicamento industrial.

Talvez, os desvios de qualidade possam estar relacionados com as propriedades farmacológicas do princípio ativo, sua farmacodinâmica ou farmacocinética, ou ainda, há a possibilidade de enantiomerização do mesmo, gerando enantiômeros com propriedades farmacológicas distintas, ou toxicidade diferente do enantiômero original.

Finalmente, considera-se que os principais objetivos de toda a pesquisa foram alcançados com sucesso, onde a possibilidade de ineficácia terapêutica do medicamento pela existência de possíveis produtos de degradação/ impurezas intrínsecas não foi confirmada através da análise do padrão do princípio ativo e do medicamento industrial fornecido pelo laboratório farmacêutico fabricante. 


\section{REFERÊNCIAS}

[1] VOGE, A. Análise química quantitativa. 6 ed. Rio de Janeiro: LTC, 2002.

[2] BRASIL. Agência Nacional de Vigilância Sanitária. Resolução da Diretoria Colegiada. RDC 17, de 16 de abril de 2010. Dispõe sobre boas práticas de fabricação de medicamentos. Disponível em: http://bvsms.saude.gov.br/bvs/saudelegis/anvisa/2010/res0017_16_04_2010.html. Acesso em: 30/ abr.2012

[3] ORGANIZAÇÃO MUNDIAL DE SAÚDE (OMS).Departamento de medicamentos essenciais e outros medicamentos. Medicamentos falsificados: diretrizes para 0 desenvolvimento de medidas de combate a medicamentos falsificados. Brasília: Organização Pan-Americana da Saúde, 2005.

[4] ORGANIZAÇÃO MUNDIAL DE SAÚDE (OMS).Counterfeit drugs.Bulletin of the world health organization, v. 7, n. 3-4, p.464,1993.

[5] BRASIL. Agência Nacional de Vigilância Sanitária.Farmacopeiabrasileira. 4 ed. Comissão Permanente de Revisão da farmacopeia Brasileira. Parte II, fascículo 2. São Paulo: Atheneu, 2000.

[6] Gil, ES. Controle físico-químico de qualidade de medicamentos. 3 ed. São Paulo: Pharmabooks, 2010.

[7]BRASIL. Agência Nacional de Vigilância Sanitária. Cloridrato de Bupivacaína. Disponível em: http://www4.anvisa.gov.br/base/visadoc/BM/BM[25743-2-0].PDF Acesso em: 30 abr. 2012.

[8] HANSEL, HC; POPOVICH, NG; ALLEN Jr, LV. Farmacotécnica: formas farmacêuticas e sistemas de liberação de fármacos. 8 ed. São Paulo, 2007.

[9] BRANDÃO, ACC. Ensaios para o laboratório de controle da qualidade e controle da produção de medicamentos. 2001. Disponível em: http://www.boaspraticasfarmaceuticas.com.br/includes/ensaios_lab_medicamentos.p df. Acesso em: 30 abr. 2012. 
[10] BRASIL. Agência Nacional de Vigilância Sanitária. Consulta Pública no 43, de 7 de julho de 2004. Guia para estudos de estabilidade de Medicamentos. Disponível em: http://www4.anvisa.gov.br/base/visadoc/CP/CP\%5B7760-1-0\%5D.PDF Acesso em: 30 abr. 2012.

[11] COLLINS, CH; BRAGA, GL; BONATO, PS. Fundamentos de cromatografia. Campinas: UNICAMP, 2006.

[12] REIS, F. Cromatografia líquida de alta eficiência.HPLC. 2009. Disponível em: http://pfarma.com.br/farmaceutico-industrial/130-cromatografia-liquida-de-altaeficiencia-.html. Acesso em: 30 abr. 2012.

[13] FIJALEK, Z; BACZYNSKI, E; PIWONSKA, A; WAROWNA-GRZESKIEWICZ, M. Determination of local anaesthetics and their impurities in pharmaceutical preparations using HPLC method with amperometricdetection. Journal of Pharmaceutical and Biomedical Analysis. 37(2005)913-918.

[14] British Pharmacopoia, London,v. 1,2010.

[15] Mc MURRY, J. Químicaorgânica. v. 1, Ed.Thomson, 2005.

[16] SOLOMONS, TWG. Química orgânica. v. 1, Rio de Janeiro: LTC, 2005.

[17]HERMANSSON,J. Direct Liquid chromatographic resolution of racemic drugs using $\alpha_{1}$-acid glycoprotein as the chiral stationary phase. Journal of Chromatography A,v. 269,1983,pages 71-80.

[18] TORBJÖRN, A. Determination of free concentration of ropivacaine and bupivacaine in blood plasma by ultrafiltration and coupled-column chromatography. Journal of Chromatography B,v. 668, Issue 1, 9/06/1995, pages 91-98.

[19] CIENFUEGOS, F. Análise instrumental. 2003. Disponível em: http://www.quimicaederivados.com.br/revista/qd413/analise_instrumental1.htm. Acesso em: 28 agosto 2010.

[20] https://knowitallanyware.com/ acesso em 14/04/2013.

[21] NETZ, PA; ORTEGA, GG. Fundamentos de físico-química: uma abordagem conceitual para as ciências farmacêuticas.Porto Alegre: Artmed, 2002. 
[22] SKOOG, DA. Princípios de análise instrumental. 5 ed. São Paulo: Bookman, 2002.

[23] WHO. Expert committee on specifications for pharmaceutical preparations.Disponível em: $\mathrm{http}: / /$ whqlibdoc.who.int/trs/WHO_TRS_908.pdf\#page= 46.2003.Acesso em:20/11/2012

[24] ANSEL, HC; POPOVICH, NG; ALLEN Jr., L.V. Farmacotécnica: formas farmacêuticas e sistemas de liberação de fármacos. 6 ed. São Paulo, 2000.

[25] SIMEONI, LA. Química farmacêutica. Roteiro de Aulas Práticas. Brasília: UnB, 2000.

[26] BRASIL. Agência Nacional de Vigilância Sanitária, Ministério da Saúde; Farmacopeia Brasileira, 4 Edição, 2000.

[27] SIMON, P; VEVERKA, M; OKULIAR, J. New screening method for the determination of stability of pharmaceuticals. International Journal of Pharmaceutics, Elsevier, Amsterdam, v. 270, n. 1-2, p. 21-26, 2004.

[28] SCHWARZ, E; DE BUHR, J. Pharmaceuticals. Collected Applications.ScienceDirect.Mettler-Toledo, Schwerzenbach. 1998.

[29] HÖHNE, G; HEMMINGER, W; FLAMMERSHEIM, HJ.DifferentialScanning Calorimetry.Springer-Verlag, Berlin, Heidelberg,1996.

[30] LOPES, JLC. Fundamentos de cromatografia. Campinas: UNICAMP, 2006.

[31] United States Pharmacopeia. Promoting the quality of medicines in developing countries, 2009.

[32] MELO, MM. Vigilância sanitária de medicamentos. Cespemed. 2004. Disponível em http://www.farmacia.ufmg.br/cespmed/text6.htm.2010.Acessoem: 10/04/2013.

[33] PLUGGE, W; VAN DER VLIEST, C. The use of near infrared spectroscopy in the quality control laboratory of the pharmaceutical industry. J Pharm Biomed Anal. Amsterdam, v. 10, n. 10-12, p.435-442, 1992. 
[34] MACDONALD, BF; PREBBLE, KA. Some applications of near-infrared reflectance analysis in the pharmaceutical industry. J Pharm Biomed Anal., Amsterdam, v. 11, n.11-12, p.1077-1085, 1999.

[35] DREASSI, E; CERAMELLI, G; CORTI, P; PERRUCCIO, PL; LONARDI, S. Application of near-infrared reflectance spectrometry to the analytical control of pharmaceuticals: ranitidine hydrochloride tablet production. Analyst, London, v. 121, n. 2, p.219-222, 1996.

[36] BLANCO, M; COELLO, J; ITURRIAGA, H; PEZUELA, C. Near-infrared spectroscopy in the pharmaceutical industry. Analyst, Barcelona, v. 123, p.135150,1998 .

[37] BLANCO, M; COELLO, J; EUSTAQUIO, A; ITTURRIAGA, H; MASPOCH, S. Development and validation of methods for the determination of miokamycin in various pharmaceutical preparations by use of near infrared reflectance spectroscopy. Analyst, London, v. 124, n. 7, p. 1089-1092, 1999a.

[38] BLANCO, M; COELLO, J; ITURRIAGA, H; MASPOCH, S; POU, N. Development and validation of a near infrared method for the analytical control of a pharmaceutical preparation in three steps of the manufacturing process. Fresenius J. Anal. Chem., Berlin, v. 368, n. 5, p. 534-539, 2000a.

[39] HERKERT, T; PRINZ, H; KOVAR, K. One hundred percent online identity check of pharmaceutical products by near-infrared spectroscopy on the packaging line. Eur. J. Pharm. Biopharm., London, v. 51, n.1, p.9-16, 2001.

[40] SABIN, JG; FERRÃO, MF; FURTADO, JC. Análise multivariada aplicada na identificação de fármacos antidepressivos. Parte II: Análise por componentes principais (PCA) e o método de classificação SIMCA. Revista Brasileira de Ciências Farmacêuticas, São Paulo, v. 40, n.3, July/Sept., 2004.

[41] CORTI, P; DREASSI, E; LEONARDI, S. Near infrared reflectance analysis: features and applications in pharmaceutical and biomedical analysis. Farmaco, Pavia, v.48, n.2,p 3-20, 1993.

[42] TRAFFORD, AD; JEE, RD; MOFFAT, AC; GRAHAM, PA. Rapid quantitative assay of intact paracetamol tablets by reflectance near-infrared spectroscopy. Analyst., London, v. 124, n. 2, p.163-167, 1999. 
[43] BLANCO, M; COELLO, J; EUSTAQUIO, A; ITTURRIAGA, H; MASPOCH, S. Development and validation of a method for the analysis of a pharmaceutical preparation by near-infrared diffuse reflectance spectroscopy. J. Pharm. Sci., Washington, v. 88, n.5, p.551-556, $1999 \mathrm{~b}$.

[44] GUO, JH; SKINNER, GW; HARCUM, WW; MALONE, JP; WEYER, LG. Application of near-infrared spectroscopy in the pharmaceutical solid dosage form. Drug Dev. Ind. Pharm., New York, v.25, n.12, p.1267-1270, 1999.

[45] BLANCO, M; EUSTAQUIO, A; GONZALEZ, JM; SERRANO, D. Identification and quantitation assays for intact tablets of two related pharmaceutical preparations by reflectance near-infrared spectroscopy: validation of the procedure. J. Pharm. Biomed. Anal., Amsterdam, v. 22, n.1, p.139-148, 2000 b.

[46] BLANCO, M; COELLO, J; ITURRIAGA, H; MASPOCH, S; POU, N. Influence of the procedure used to prepare the calibration sample set on the performance of near infrared spectroscopy in quantitative pharmaceutical analyses. Analyst, London, v. 126, n. 7, p.1129-1134, 2001.

[47] LAASONEN, M; HARMIA-PULKKINEN, T; SIMARD, C; RASANEN,M; VUORELA, $H$. Development and validation of a near-infrared method for the quantitation of caffeine in intact single tablets. Anal.Chem., Washington, v.75, n.4, p.754-760, 2003.

[48] SUN, ML; XIANG, BR; AN, DK. A near-infrared diffuse reflectance analysis method for the noninvasive quantitative analysis of ambroxol hydrochloride tablets. Yao Xue Xue Bao, Peking, v.39, n.1, p.60-63, 2004.

[49] LUYPAERT, J; MASSART, DL; VANDER, HY. Near-infrared spectroscopy applications in pharmaceutical analysis.Talanta, v. 72, 2007.

[50] BLANCO, M; COELlO, J; ITURRIAGA, H; PEZUELA, C. Near-infrared spectroscopy in the pharmaceutical industry. Analyst,Barcelona, v. 123, p.135150,1998 .

[51] GÖRÖG, S. Drug safety, drug quality, drug analysis. Journal of Pharmaceutical and Biomedical Analysis, Budapest, v. 48,p.247-253, 2008.

[52] VILELA, MAP; AMARAL, MPH. Controle da qualidade na farmácia de manipulação. 3 ed.Juiz de Fora: Universidade Federal de Juiz de Fora, 2008. 
[53] LEITE, F. Validação em análise química. 5 ed. Campinas: Editora Átomo, 2008.

[54] KOROLKOVAS, A. Dicionário terapêutico Guanabara. Rio de Janeiro: Editora Guanabara, 2007/2008.

[55] SWARTZ, ME; KRULL, IS. Developing and validating Stability-indicating methods. LCGC June 1,2005.

[56] USA. Guidance for industry, analytical procedures and method validation, U.S. Departament of health and human services FDA, August 2000. Disponível em: www.fda.gov/guidande/index.htm. Acesso em: 02 maio 2013.

[57] D.W. Reynolds, K. L. Facchine, J. F. Mullaney, K. M. Alsante, T. D. Hatajik, M. G. Motto. Available Guidance and best practices for conducting forced degradation studies.Pharnaceutical Technology,Gebruarypag 48-56, 2002.

[58] BAKSHI, M; SINGH, S. Development of validated satability-indicating assay methods-critical review. Journal of Pharmaceutical and biomedical analysis, $28 \mathrm{p}$. 1011-1040, 2002.

[59] International Conference on Harmonization ICH Q1A (R2)): Stability testing of new drug substances and products. Geneva, 2005. Disponível em:www.ich.org.Acesso em: 05 maio 2014.

[60] United States Pharmacopeia, 33st ed., The United States Pharmacopeial Convention 12601, Rockville, 2010.

[61] BAERTSCHI, SW. Pharmaceutical stress testing: Prediction drug degradation. Informa Healthcare, p.482, 2005.

[62] SMELA, MJ. Regulatory Considerations for Stability Indicating Analytical Methods in Drug Substance and Drug Product testing. Disponível em: www.americanpharmaceuticalrevieu.com.Acesso em: 07 maio 2014.

[63] REYNOLDS, DW; FACCHINE, KLJ; MULLANEY, F; ALSANTE, KM; HATAJIK, TD; MOTTO, MG. Available guidance and best practices for conducting forced degradation studies, Pharmaceutical Technology, 26 p. 48-54, 2002. 
[64] STEWART, PJ; TUCHER, IG. Prediction of drug stability. Part 2.Hydrolysis. Aust. J. Hosp. Pharm. 15 (1), p. 11-16, 1985.

[65] ALSANTE, K. M; ANDO, A; BROWN, R; ENSING, J; HATAJIK, TD; KONG, W; TSUDA, Y. The role of degradant profiling in active pharmaceutical ingredients and drug products. Advanced Drug Delivery Reviews 59 p. 29-37, 2007.

[66] S. W. Baertschi, P. J. Jansen. Stress testing: A predictive tool in Pharmaceutical stress testing. Predicting drug decradation edited by $\mathrm{S}$. W. Baertschi.Informa Healthcare. p.13-49.

[67] International Conference on Harmonization ICH Q1B: photostability testing of New Drug Sbstances and Products Geneva 1996 www.ich.orgAcessoem: 14 julho 2014.

[68] DOLAN, JW. Stability-Indicating assays. LC-GC Europe may 2002 Disponível em: www.lcgeurope.com.Acesso em:12 jun 2014.

[69] Disponível em: http://www.chemblink.com/products/87-62-7.htm. Acesso em: 23 out 2014.

[70] Disponível em: http://www.chemblink.com/products/95-53-4.htm. Acesso em: 23 out 2013.

[71] BRASIL. Ministério da Saúde. Agência Nacional de Vigilância Sanitária. Guia para qualidade em química analítica: uma assistência à habilitação.Brasília, 2006.

[72] BRASIL. Agência Nacional de Vigilância Sanitária. RE no 899, de 29 de maio de 2003. Determina a publicação do Guia para validação de métodos analíticos e bioanalíticos. D.O.U. - Diário Oficial da União; Poder Executivo, de 02 de junho de 2003

[73] SÄNGER, EC; HEDELAND, Y; PETTERSSON, C; Capillary Electrophoresis: an Atractive Technique for Chiral Separations; Chromatography Today. p.32-37, 2013.

[74] United States Pharmacopeia: USP 34. Rockville: United States Pharmacopeial Convention, 2011,v.2. p.2087-2088 
[75] BÖCKEL, WJ; MARTINI, EMA.; SAMIOS, D; PIATNICKI, CMS. A laboratorymade capillary electrophoresis equipment with conductometric detection; Quím. Nova vol.28 n. 6 São Paulo Nov./Dec. 2005. 